\title{
Global Nuclear Markets - Market Arrangements and Service Agreements
}

Brent Dixon

Leilani Beard

June 2016

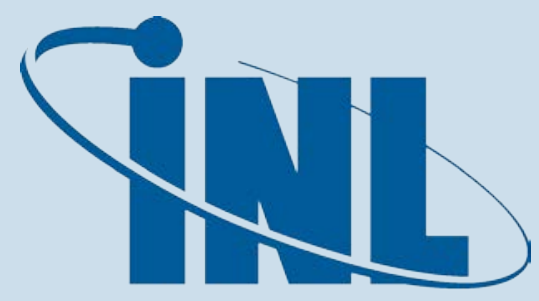

Idaho National

The INL is a U.S. Department of Energy National Laboratory operated by Battelle Energy Alliance 


\section{DISCLAIMER}

This information was prepared as an account of work sponsored by an agency of the U.S. Government. Neither the U.S. Government nor any agency thereof, nor any of their employees, makes any warranty, expressed or implied, or assumes any legal liability or responsibility for the accuracy, completeness, or usefulness, of any information, apparatus, product, or process disclosed, or represents that its use would not infringe privately owned rights. References herein to any specific commercial product, process, or service by trade name, trade mark, manufacturer, or otherwise, does not necessarily constitute or imply its endorsement, recommendation, or favoring by the U.S. Government or any agency thereof. The views and opinions of authors expressed herein do not necessarily state or reflect those of the U.S. Government or any agency thereof. 


\title{
Global Nuclear Markets - Market Arrangements and Service Agreements
}

\author{
Brent Dixon \\ Leilani Beard
}

June 2016

\begin{abstract}
Idaho National Laboratory
Nuclear Systems Design \& Analysis Division Idaho Falls, Idaho 83415
\end{abstract}

\author{
Prepared for the \\ U.S. Department of Energy \\ Office of Energy Policy and Systems Analysis \\ Under U.S. Department of Energy-Idaho Operations Office \\ Contract DE-AC07-05ID14517
}





\section{Forward}

The U.S. Department of Energy's Office of Energy Policy and Systems Analysis (EPSA) requested an assessment of global nuclear markets, including the structure of nuclear companies in different countries and the partnerships between reactor vendors and buyers. EPSA was interested in obtaining information on the competitive context of international sales of reactors and fuel services. The Idaho National Laboratory responded to this request with a plan for information gathering and assessment of global markets in several phases. The first phase researched global sources and developed a collection of information to assist in the analyses of the global market status and trends in services provided in conversion, enrichment, reactor design, construction and operation, and used fuel management and reprocessing. This report summarized this first phase, including analysis conclusions about current global markets. Additional phases will address specific topics that are of particular interest to EPSA. 


\section{SUMMARY OF KEY FINDINGS}

The U.S. Department of Energy's Office of Energy Policy and Systems Analysis (EPSA) requested an assessment of global nuclear markets, including the structure of nuclear companies in different countries and the partnerships between reactor vendors and buyers.

This report documents the findings of the first phase of the Global Nuclear Markets project, along with a description of the work performed. This includes findings on the countries and companies involved with trade in nuclear reactors and fuel services, market arrangements, and service agreements, in conversion, enrichment, reactor design, construction and operation, and used fuel storage and reprocessing, along with assessment of the trends in these areas.

The work was conducted by collecting information of nuclear facilities and service providers, and performing an extensive open-sourced literature search to validate and update the information and to identify agreements and relationships between countries and companies. Chronological information was developed to assist in the identification of market trends. Analysis was then performed to assess overall market conditions and develop insights on developments with the major players.

Extensive lists of existing and planned fuel cycle facilities and reactors under construction or planned were developed and general relationships between suppliers and customers identified. Specific relationship identification was limited due to a lack of publicly available information for a systematic assessment. The main sources of facility information were found to be slightly dated and not always in agreement, especially with respect to the status of planned reactor projects and the capacities of existing conversion and enrichment facilities. Efforts to validate data in these areas revealed the constantly changing nature of the information.

The main conclusions of the work include:

- Financing for a new nuclear reactor projects continue to be a significant obstacle for most countries wanting to include nuclear in their energy mix.

o Countries like China and Russia that have the ability to offer financing terms for reactor construction that are outside of the OECD Financing Nuclear projects guideline can have a competitive advantage.

- Reactor construction performance seems to have a major impact on where growth is occurring and which providers are obtaining new business.

o Average construction times under 6 years in Korea and China may be contributing to domestic growth while also providing a competitive advantage for exports by reducing perceived project risk.

o Conversely, established vendors that are struggling to complete current projects may be at a disadvantage for future sales, depending on customer perception of the reasons for project delays.

- Geopolitics may influence reactor projects and reactor vendor choices for smaller countries.

o Russia often has the inside track for new projects in countries with strong political ties.

o China's initial exports are to Pakistan, which has strong trading ties with China.

- Some prototype and demonstration SMRs are under construction and many others are in development. While many countries have expressed interest in SMRs, significant commercial orders have not yet materialized.

- Some progress in fielding prototype advanced "Generation IV" reactors was observed, especially for sodium-cooled fast reactors where Russia and India are both currently completing larger plants. A prototype high temperature gas reactor is under construction in China. 
- The Fukushima accident continues to have strong repercussions within Japan, with only limited restarts of existing reactors and lower targets for nuclear energy's market share going forward.

o Outside of Japan, the impact of Fukushima on the reactor construction industry has been mixed with countries with struggling programs or overall low energy demand growth apparently impacted more than countries with thriving programs and higher energy demand growth.

o The prolonged shutdown of reactors in Japanese reactors and slower growth globally has had a greater impact on the fuel supply chain.

- Each stage of the fuel cycle front end appears to have ample supply capacity to meet current and near-term demand

o Spot prices for yellowcake, conversion and enrichment are all down significantly since Fukushima. Some new enrichment facilities have been postponed or cancelled.

o While reactor vendor typically provide fuel for the initial years of operations for new reactors, more fuel supplier diversification and competition is occurring for refueling of reactors when fuel contracts come up for renewal.

o The European Union is requiring new reactors to have more than one fuel supplier in the medium term to improve security of supply.

o Westinghouse is emerging as a second supplier of VVER fuels outside Russia. 


\section{CONTENTS}

Forward

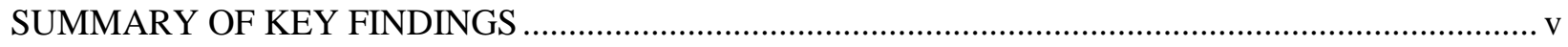

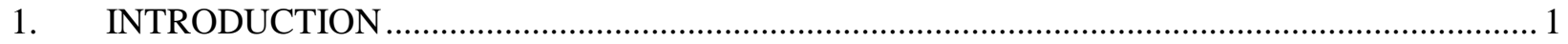

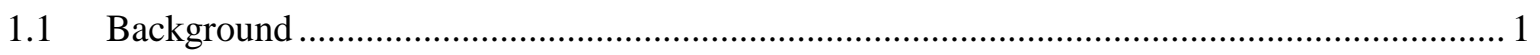

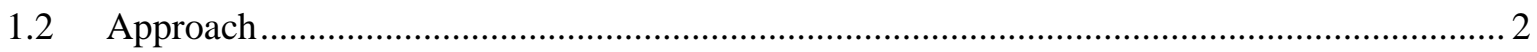

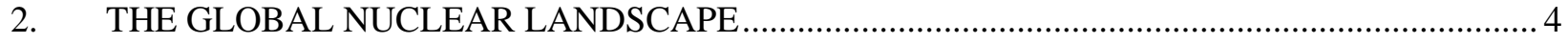

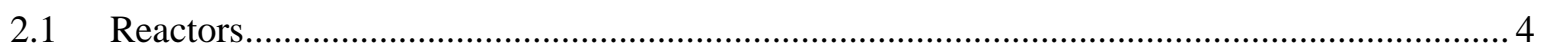

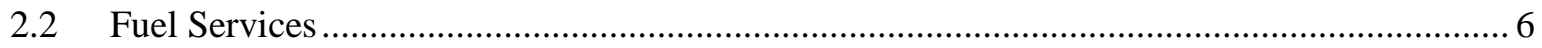

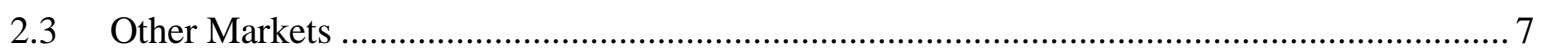

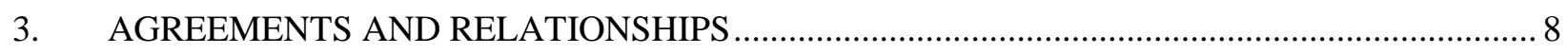

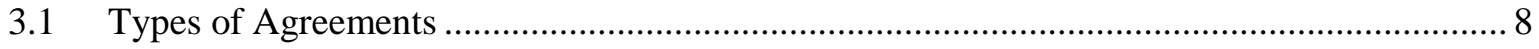

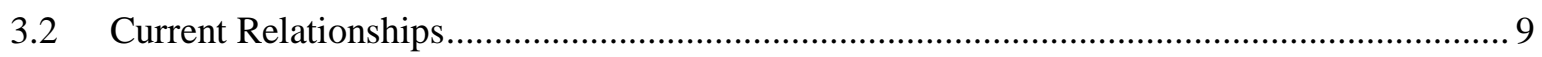

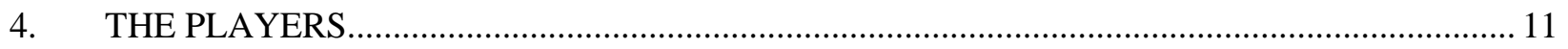

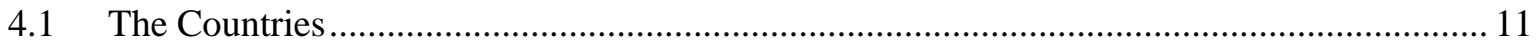

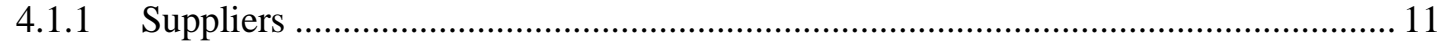

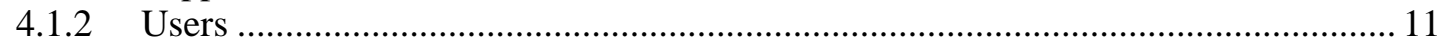

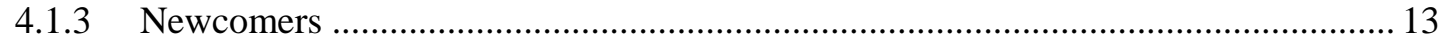

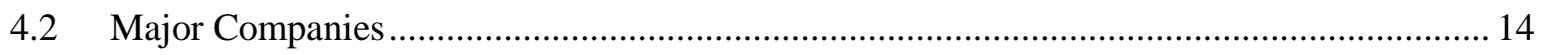

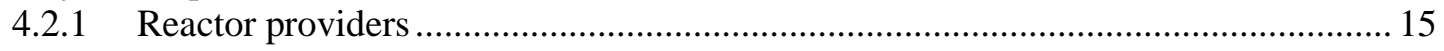

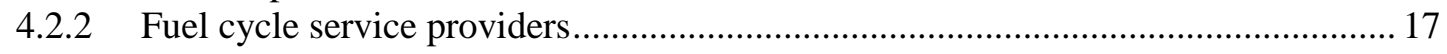

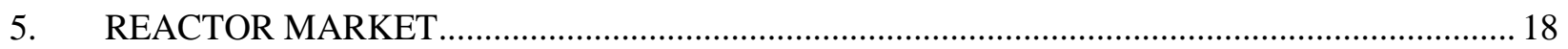

5.1 Historic Reactor Market Patterns ……........................................................................... 18

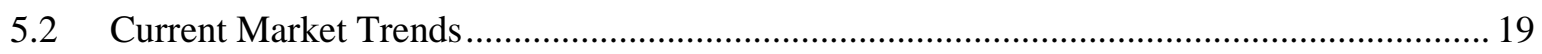

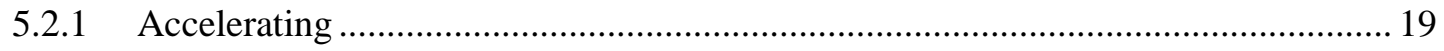

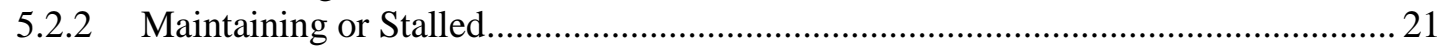

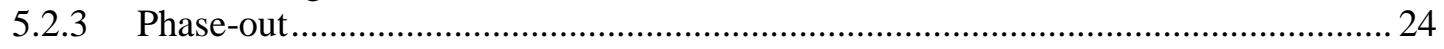

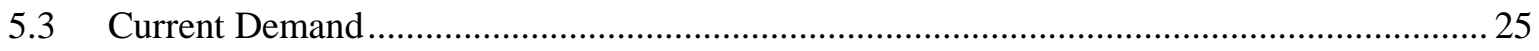

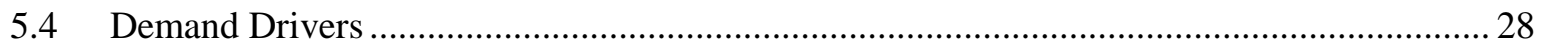

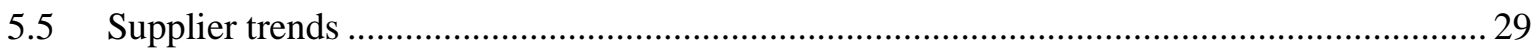

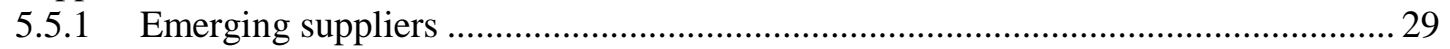

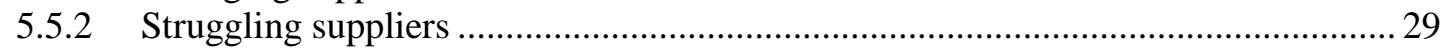

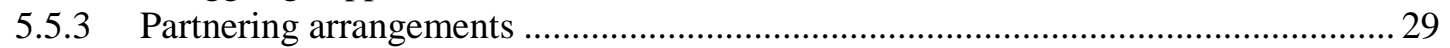

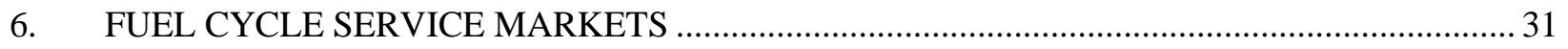

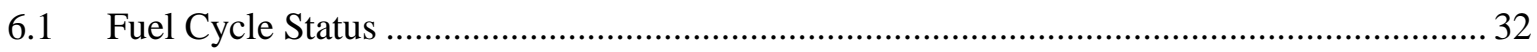

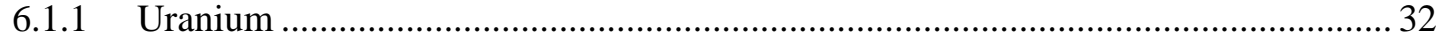

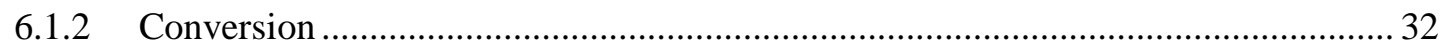

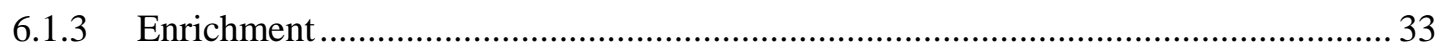

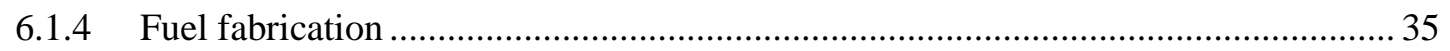




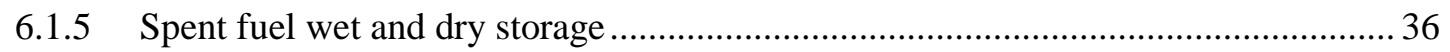

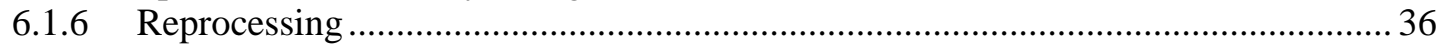

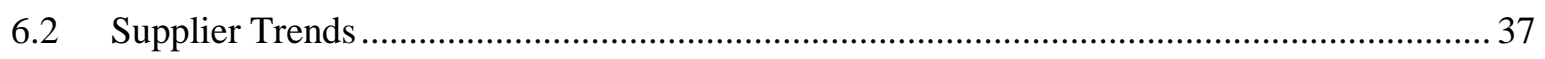

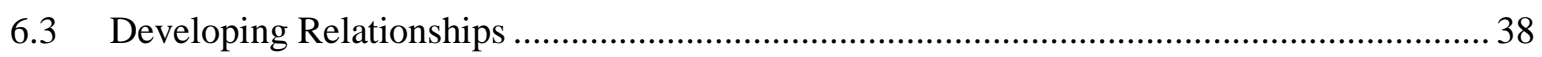

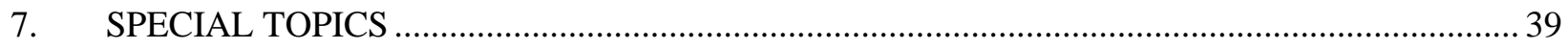

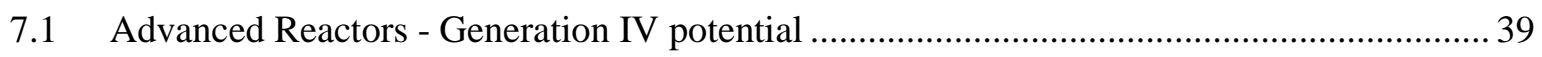

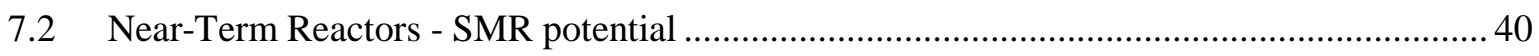

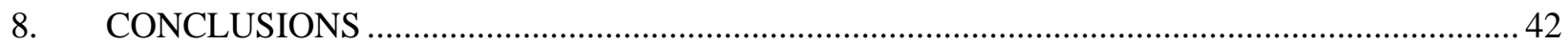

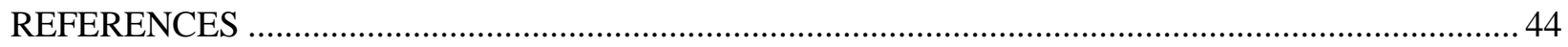

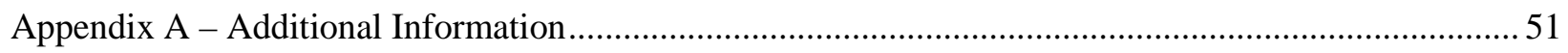

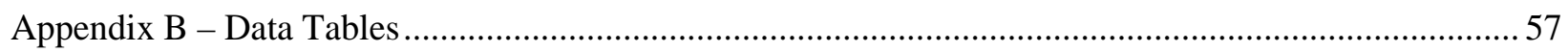

\section{FIGURES}

Figure 1 - Reactor construction start year versus duration showing historic themes - a) United

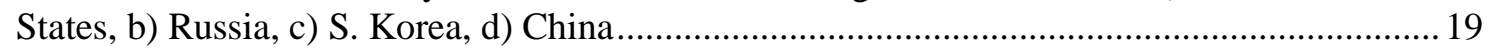

Figure 2 - Reactor construction start year versus duration in fourteen countries .................................... 56

\section{TABLES}

Table 1 - Major Export Countries and Potential Importers.................................................................... 9

Table 2 - Listing of countries with involvement in nuclear energy with hyperlinks to country

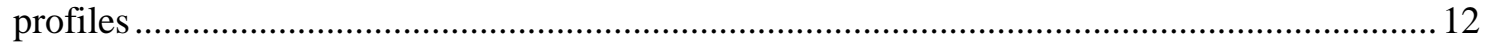

Table 3 - WNA list of countries expressing some level of interest developing nuclear power

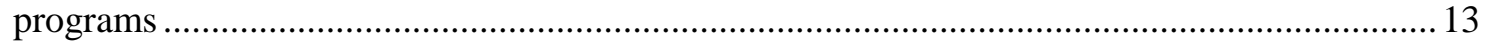

Table 4 - WNA list of newcomer countries by level of progress in developing nuclear power

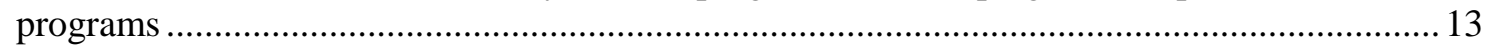

Table 5 - Primary Export Companies and the Markets They Serve …..................................................... 16

Table 6 - Countries with smaller long-established nuclear programs and plans for expansion.................. 20

Table 7 - Market shares of new LWR/PHWR reactor construction by vendor ........................................ 26

Table 8 - Supplier countries and reactor vendors for current and likely construction projects ................. 27

Table 9 - Information on current global conversion facilities .............................................................. 33

Table 10 - Information on current major global enrichment facilities (IAEA) …................................... 35

Table 11 - Information on current global reprocessing facilities .............................................................. 37

Table 12 - Categorization of status of new reactor projects...................................................................... 52 



\section{GLOBAL NUCLEAR MARKETS}

\section{MARKET ARRANGEMENTS AND SERVICE AGREEMENTS}

\section{INTRODUCTION}

The purpose of the Global Nuclear Markets project is to provide an assessment of the status and trends in global nuclear power markets. This report documents the findings of the first phase of the Global Nuclear Markets project, along with a description of the work performed.

The nuclear power markets addressed in this report include the design/construction of reactors, and the nuclear fuel cycle services of conversion, enrichment, fuel fabrication, used fuel storage and reprocessing. A brief description of the nuclear fuel cycle is included as Appendix A-1. These markets are the focus of this report because they constitute the majority of sales and also influence business relationships in additional nuclear markets.

A number of additional markets are not covered, including component manufacturing and a wide range of services such as personnel training, reactor refueling, and regulatory advisory and legal services. These markets can include substantial sales, especially for components and refueling maintenance. However, business relationships in these areas are less likely to be tied to business in other nuclear markets.

\subsection{Background}

Civilian nuclear power was originally developed after World War II as a peaceful use of nuclear fission [1]. A wide range of reactor designs were researched, including those already developed for military purposes, with four basic designs becoming widely deployed for electricity generation. These included graphite moderated Gas Cooled Reactors (GCRs), primarily deployed in the United Kingdom (UK) and France, Pressurized Heavy Water Reactors (PHWRs), primarily deployed by Canada and India, Light Water Graphite Reactors (LWGRs) deployed by the Soviet Union, and Light Water Reactors (LWRs), initially deployed by the United States (U.S.) and the Soviet Union and later adopted by others. Of these, the LWRs were the most successful and account for over $90 \%$ of the power reactors in the world. Two primary designs of LWRs have been deployed throughout the world, the boiling water (BWR) and pressurized water (PWR). Of all the reactor types, the PWRs, BWRs, and PHWRs are actively being built today. There are also a very limited number of prototypes/demonstrations of other designs in operation or under construction, including sodium-cooled fast reactors (SFRs) and high temperature versions of gas cooled reactors.

The original "Generation I" power reactors were small prototypes, with those completed prior to 1960 under 100 MWe. Larger "Generation II" reactors were widely deployed starting in the 1970s, and are the majority of reactors operating worldwide today. Evolutionary improvements in economics, safety and other areas resulted in "Generation III" and Generation III+" advanced LWRs deployed in the 1990s through today, with most over 1,000 MWe in size and the largest being 1,700 MWe. Research is now focused on "Generation IV" reactors [2] that move beyond LWR technologies and "Small Modular Reactors” (SMRs). The SMRs are a reversal to the trend of large reactor designs. The SMR design approach is to improve economics by using factory fabrication methods and simplified designs and employ a scalability feature where each reactor being under 300 MWe. The SMRs include a mix of LWRs and Generation IV advanced reactor types, with the LWR-based designs closer to deployment.

Like reactors, the initial fuel facilities for the nuclear industry were originally developed for military purposes. As the industry grew and technologies advanced, these were mostly replaced by newer civilian facilities. The functions of conversion and enrichment are fungible and the markets have evolved to 
include only a few large facilities world-wide. In contrast, fuel is a highly engineered and custom fabricated product [3]. Each major reactor vendor initially had their own fuel design and developed associated fuel fabrication facilities. The most popular designs were the square lattice Westinghouse, Babcock \& Wilcox, and Combustion Engineering PWR assemblies, the hexagonal Russian VVER PWR assembly, the General Electric square lattice BWR modules, the UK circular array GCR fuel assembly, the Russian RBMK circular array LWGR bundles, and the CANDU circular array PHWR bundles. The enrichment of the fuel pellets within each assembly is customized based on the operating cycle of the individual reactor (typically 12 or 18 months), number of batches in the core, and desired fuel burn-up. Higher burn-up in LWRs is desirable to limit the frequency of refueling. Consolidation of fuel fabricators has been occurring and competition for fabrication in reload fuel for most LWRs had developed. The exception had been VVER fuels, where the Russian state company (Rosatom) had maintained a monopoly well after the dissolution of the Soviet Union, but is now also seeing competition.

On the back end of the fuel cycle, the majority of fuel is stored on-site at the reactors pending future disposal or possibly future reprocessing. Fuel reprocessing facilities are currently only operating in France, Russia and the UK, and few countries currently use reprocessing services. This is primarily because there is little demand for plutonium, which is the primary reprocessing product. Plutonium can be used in mixed oxide U/Pu fuel in some LWRs, but the fuel is 3 to 4 times more expensive to fabricate and only reduces uranium mining and enrichment by $\sim 15 \%$. $^{\mathrm{a}}$

\subsection{Approach}

This work was conducted by first collecting lists of nuclear facilities and service providers, and performing an extensive literature search to validate and update these lists and to identify agreements between countries and companies on these lists. Chronological information was developed to assist in the identification of market trends. Analysis was then performed to assess overall market conditions and develop insights on developments with the major players.

The primary sources for identifying global facilities and service providers were the International Atomic Energy Agency (IAEA) and the World Nuclear Association (WNA), including the IAEA's Power Reactor Information System (PRIS) [4], Country Nuclear Power Profiles (CNNP) [5], and the WNA's Information Library Country Profiles [6]. Readers not familiar with the nuclear programs of specific countries are encouraged to access the IAEA and WNA country profiles, as they contain helpful information on both the history and current status of the programs and provide links into more detailed information. Table 2 in Chapter 3 provides access to these profiles through hyperlinks. Additional information was located on the web sites of the Organization for Economic Cooperation and Development (OECD) - Nuclear Energy Agency (NEA) and the U.S. Energy Information Agency (EIA). Collectively, there is a large amount of information accessible through these sources, including numerous databases and report libraries.

The above sources were used to develop lists of facilities and suppliers that were then cross-verified, augmented, and in some cases brought up to date through web searches. Suppliers were generally identified by the parent company, with the primary focus to identify the home country of the parent and capture additional information found. Information on owners and relationships between parent companies and subsidiaries was captured throughout the effort, but is by no means considered to be

\footnotetext{
${ }^{a}$ This may change if fast reactors move from their current prototype status to wider deployment, since they are theoretically able to continuously recycle plutonium and reduce uranium needs by $\sim 99 \%$. The promise of this "closed" fuel cycle is the main driver behind maintaining the limited reprocessing and mixed oxide fuel fabrication occurring today.
} 
complete as many of these companies have dozens of subsidiaries, subsidiaries of subsidiaries, etc. and many are also under shared ownership.

Information on agreements and relationships were also developed from news articles, where the primary source was the Nuclear Energy Institute's (NEI) NEI SmartBrief, a daily summary of news items for the nuclear industry. The NEI SmartBrief archives [7] were accessed and searchable files of the briefs developed for the last seven years. This allows for text searches on agreements, by country, by company, etc. to find one paragraph summaries of news events with hyperlinks to the originating articles on the web. While many of the articles are no longer accessible, others can be accessed - especially World Nuclear News and Reuters, which cover a good percentage of the international news items. This information source is expected to be quite valuable for researching and addressing new questions that EPSA may have relative to market trends.

Some additional consistency-checking was performed by reviewing presentations from international meetings attended by the Principal Investigator (PI) over the last few years.

A number of data challenges were noted during information collection, as described here and more fully in Appendix A-1. First, different information sources reported status differently, including whether a project was in planning or cancelled, when construction starts or ends, and how to address pauses in construction or operations. For example, Table 4 in Section 4.1.3 is how one source listed planning status. Tracing of subsidiaries back to their parent companies required additional steps. Differing spelling of foreign company and facility names and reuse of site names for new projects were also challenges.

A OneNote project file was developed to contain the information gathered and the information was also summarized in a spreadsheet of suppliers, reactors and fuel cycle facilities that includes numerous hyperlinks to web sites with more detailed information on facilities and events. This spreadsheet is sortable and includes proposed, planned, under construction, and closed facilities along with location, ownership, and other information useful for this effort.

The gathered data and information was then consulted as needed to support the assessments in the body of this report. While this included development of summary tables and graphs, as well as analyses of capacities, the data and information was primarily used to look for patterns and form opinions about market trends. 


\section{THE GLOBAL NUCLEAR LANDSCAPE}

Globally, there are currently 445 nuclear reactors with a combined 387 gigawatt (GWe) capacity operating in 30 countries and 64 reactors under construction in 15 countries. In 2015, 10 new reactors came online and 8 were permanently shut down, which along with uprates resulted in a net capacity increase of 4.5 GWe [8]. The OECD International Energy Agency 2015 Global Energy Outlook Report projects that nuclear power will have to double by 2050 for the world to meet the international climate change goals and the energy needs of an expanding global population, which is expected to grow to 10 billion by 2050. Many countries continue to express interest in developing or expanding their nuclear programs, although low oil and gas prices could make it harder for governments to favor policies that encourage the use of nuclear energy and other clean energy sources.

Some recent developments have marked the significance of global nuclear power. The most recent was the 2015 Paris Climate Conference, which recognized the importance of nuclear energy to meet global carbon reduction goals. The International Atomic Energy Agency's Convention for Supplementary Compensation for Nuclear Damage (CSC) nuclear liability regime entered into force on April 15, 2015. China kept its place as the fastest growing market for nuclear energy. Eight reactors came online in 2015, bringing China's total to 30 operating reactors; China also announced plans to export its reactor technology.

Nuclear markets continue to shift, with recent movement toward East Asia, the Middle East, South America, Africa, and Eastern and Central Europe. This has important implications for the global nuclear landscape after 2030. The U.S. Government estimates that the global civil nuclear market focused on reactor sales to be valued to be between $\$ 500$ and $\$ 740$ billion over the next 10 years [9].

The potential sales in the coming years are significant, especially for the two sectors of the nuclear market primarily addressed in this report, reactor builds and fuel services. The report provides a snapshot of the status of the global new builds, discusses new reactor technologies that will enter the market in the nearterm, and the status of more advanced reactor designs being developed in the long-termer. In the fuel services the report focuses on supply and demand for conversion, enrichment, fuel fabrication and reprocessing.

An excellent but somewhat dated resource for detailed information about nuclear markets is a 2008 report by the Nuclear Energy Agency [10]. A number of companies also sell detailed market analysis reports.

\subsection{Reactors}

The largest sector within nuclear market is the design and construction of reactors. Roughly $85 \%$ of the cost of nuclear electricity is reactor cost, and much of that cost is the capital cost of the reactors themselves ${ }^{\mathrm{b}}$. Due to the complexity of reactors and the evolution of the supplier market over the course of the last 20-30 years, these costs are spread across multiple vendors of reactor components, from the heavy forging of reactor vessel heads to steam generations, coolant pumps, valves, etc. A recent trend has been for newcomer countries to require localization of some portion of the manufacturing capability domestically as part of the tender and contract requirement.

A common long-term trend within the reactor market is for many larger programs to initially buy a design from a foreign vendor, then as more units are constructed and the local content of sourced components

b The U.S. Energy Information Agency estimates reactor capital costs contribute 74\%, reactor operations and maintenance costs $12 \%$, fuel costs $13 \%$ and transmission investments $1 \%$ to the total levelized cost of nuclear electricity.https://www.eia.gov/forecasts/aeo/electricity_generation.cfm 
increases, there is an effort to develop a domestic design. France and India are past examples of this pattern, while China and South Korea are more current examples. France built their PWR reactor fleet in three design classes, sized at $~ 900$ MWe, 1300 MWe and 1,450 MWe. The first two design classes (54 reactors) were based on a Westinghouse design, while the third (4 reactors) was domestically derived. France is now exporting the EPR-1750, which is based on the previous designs. Westinghouse also exported to South Korea. France exported the 900 MWe design to China. Both South Korea and China now have their own domestic designs, which are being exported to the United Arab Emirates and Pakistan, respectively, all based on Westinghouse ancestry. Canada exported PHWR technology to India prior to the 1974 Indian nuclear weapons test that halted trade. India then developed a domestic PHWR design that is the basis of most of its current reactor fleet.

This history demonstrates a transfer of nuclear reactor designs from the countries that initiated nuclear energy to the countries that are actively building reactors today. Countries actively building larger fleets of reactors have the most to gain though innovation of advanced designs. They also have the best ability to recover design costs through ongoing construction and future exports of that reactor technology. Innovative advances occur in many areas, including more efficient construction and safer and more efficient operations, providing more opportunity to accelerate technological innovation. On the other hand, previous leaders who have seen their domestic programs stagnate have also experienced difficulties with deploying their latest designs and may lose technological leadership if they are not able to maintain the level of sales necessary to recover design costs.

Another observation from the research is that countries operating small fleets of older PHWRs tend to switch to LWRs when additional capacity is developed. Argentina and Pakistan are examples where both are currently constructing LWRs while Romania is a counterexample where all currently planned reactors are PHWRs ${ }^{c}$. Of the countries with larger PHWR fleets, India is continuing to build PHWRs, but is now also developing LWR projects ${ }^{\mathrm{d}}$ while Canada is concentrating on refurbishment of existing PHWRs [11]. The UK appears to be following this pattern too, with replacement of its current fleet of GCRs with new LWRs in the works. GCRs are similar to PHWRs in fuel enrichment requirements and discharge rates.

Research and development of advanced designs continues, with new prototype or demonstration fast reactors recently completed in Russia (BN-800, $880 \mathrm{MWe}$ ), China (CEFR, $20 \mathrm{MWe}$ ) and India (Kalpakkam-1, 500 MWe, to be commissioned later this year), and a prototype high temperature gas reactor under construction in China (Shidao Bay-1, 210 MWe). However, Japan's prototype fast reactor (Monju, $246 \mathrm{MWe}$ ) is still shut down after a 2010 fuel handling accident until a government committee decides on a new operator for the reactor's management and oversight [12]. France shut down its Phenix prototype fast reactor in 2010, but is programming the construction of the Advanced Sodium Technological Reactor for Industrial Demonstration (ASTRID) by the end of the 2020s. (The U.S. shut down its last research fast reactor in 1994.)

Research and development of small modular reactors (SMRs) is also proceeding, but is not as far along, and current projects are for domestic prototypes or demonstration units. These include the CAREM prototype in Argentina and the floating reactors in Russia that are under construction, as well as demonstration units planned in several countries [13], including the U.S. The U.S. efforts include an early site permit for an SMR at Clinch River recently filed with the NRC, and an agreement signed

\footnotetext{
${ }^{\text {c }}$ Romania is also planning to host the Advanced Lead Fast Reactor European Demonstrator (Alfred) being developed under an EU initiative - http://www.world-nuclear-news.org/NN-Consortium-established-to-build-Alfred-2012134.htm

${ }^{\mathrm{d}}$ India has two small (150 MWe) BWRs that have been operating since 1969, but had problems with fuel supply after their nuclear test and resulting trade embargos. With the recent lifting of the embargo, they are planning to both continue construction of their domestic PHWRs and construction of imported designs from several countries.
} 
between the Department of Energy and Utah Associated Municipal Power Systems (UAMPS) giving UAMPS a use permit to locate an SMR at the Idaho National Laboratory site. While SMRs demonstrations are not as far along as some advanced reactors, the designs based on existing LWR technologies may be deployed commercially earlier than advanced reactors because less technology development is required. Other SMRs are modular versions of advanced reactors and will require more development.

\subsection{Fuel Services}

The nuclear fuel cycle includes front-end processes of uranium mining and milling, conversion from $\mathrm{U}_{3} \mathrm{O}_{8}$ to $\mathrm{UF}_{6}$, enrichment of ${ }^{235} \mathrm{U}$ (skipped for most heavy water reactors), conversion to $\mathrm{UO}_{2}$ and fabrication into fuel assemblies, and back-end processes of on-site wet cooling storage, either cooled storage (wet or dry) or reprocessing, and eventually disposal of spent fuel or high level waste.

A large number of uranium mines and mills are currently in operation around the world producing $\mathrm{U}_{3} \mathrm{O}_{8}$ “yellowcake,” with the primary global suppliers in 2015 being Kazakhstan (39\%), Canada (22\%) and Australia (9\%).[14] While some existing mines close and some new mines open every year, projections are for sufficient supplies through at least mid-century. Due to the large number of suppliers, including many that otherwise do not have nuclear programs, this area was not assessed in this report.

A small number of large capacity conversion plants are in operation globally, most of which have been in operation for many decades. The only major new construction in this area is in France, where AREVA is constructing the Comurhex II facility to replace existing Comurhex I facilities commissioned in 1959 and 1961. Global conversion capacity appears to be sufficient to meet global needs [15].

In the enrichment area a major technical revolution has recently been completed with the final large gaseous diffusion plants being retired and replaced with centrifuge plants. The much more energy efficient centrifuge plants have lower operating costs which may reset the global price for Separative Work Units (SWUs), reducing the cost of producing the low enriched uranium (LEU) used in all LWRs.

Global enrichment capacity appears to be sufficient to meet global demand with the current oversupply projected to continue [16]. Global demand is expected to rise with the restart of more reactors in Japan coupled with new construction globally, but new enrichment capacity is also planned, primarily in China. Spot market prices have declined steadily from a recent high of \$160/SWU in 2010 to \$60/SWU in early 2016 [17].

Unlike the mining, conversion and enrichment markets which produce a common product, the nuclear fuel fabrication market is highly specialized and produces customized products for each customer. Most fabrication is performed by the reactor vendor or a subsidiary, at least for the initial cores and first few reloads, but the trend is toward a more open market for low enriched uranium (LEU) fuels, with multiple suppliers developing fuel for the main PWR, BWR and VVER reactor designs. Suppliers of LEU fuels are also becoming multinational, with facilities in multiple countries.

In contrast to the LEU fuel fabrication market, countries with PHWR reactors have or are developing their own fuel fabrication facilities to provide some or all of their domestic needs. Since PHWRs do not require ${ }^{\mathrm{e}}$ enriched uranium, it is easier to develop a domestic fuel cycle. Also, due to low burn-up, the

e Some PHWRs are now using slightly enriched uranium $\left(0.9 \%\right.$ to $\left.2 \%{ }^{235} U\right)$ to increase burnup and reduce spent fuel volumes. 
PHWR fuel must be replaced annually instead of every $4-5{ }^{f}$ years, making it more advantageous to have a local source. The primary exporter of PHWR fuel is Canada, the developer of the CANDU family of PHWRs. However, Russia is also developing PHWR fuel fabrication capabilities [18].

On the back end, used fuel is stored for initial cooling at the reactor site. Subsequent fuel storage mostly occurs at the reactor site or at centralized locations within the country that irradiated the fuel, though there is some limited transfer between countries associated with existing or previous reprocessing arrangements. These include reprocessing in France and the UK for other western European countries and Japan, and reprocessing in Russia primarily associated with former Eastern Bloc countries that have Russian design reactors ${ }^{g}$. Russia is experimenting with a new marketing model for fuel services, offering to take back Russian fabricated fuels after irradiation, including fuel supplied to Iran [19] and likely to also include fuel for the VVER reactors under construction in Belarus and planned for Turkey.

Geologic disposal of spent fuel from a once-through fuel cycle or high level waste from reprocessing is the final stage of the fuel cycle. Currently no operating facilities exist, but one was just approved for construction in Finland in November [20].

\subsection{Other Markets}

The other market sectors were not assessed as part of this effort. These services include operations and maintenance support, assistance in setting up the country's regulatory framework, training of reactor workers, and other services. Reactor vendors may provide some of these services bundled with the primary reactor contract in newcomer countries.

Worker training continues throughout the life cycle of the associated facilities, becoming part of operations. Other areas of operations include assistance with maintenance during refueling outages, which can involve as many as 1,000 people over a period of several months leading up to and during the actual outage, which typically will last $\sim 3$ weeks.

For example, the terms for the current contract for Turkey’s first reactor, Russia's state-owned company Rosatom will provide all of the operations [21]. This is the first trial of Rosatom's "Build, Own, Operate" (BOO) business model for securing reactor sales in newcomer countries. Until an actual reactor has been build using this model it is not clear if the $\mathrm{BOO}$ will offer an alternative competitive advantage over the standard model where the host country purchases the reactor technology, and owns and operates the reactor. In general, newcomer countries view the establishment of a nuclear power program as an indicator of improved technical stature and desire the highly skilled and high-paying jobs associated with nuclear operations.

Assistance may also be provided in waste management, including sales of dry storage casks for spent fuel. Again, this is an area that was not assessed, though some agreements to provide dry storage casks were noted. Some suppliers of dry casks include U.S. based Holtec International and AREVA Tennessee (NUHOMS system).

\footnotetext{
${ }^{\mathrm{f}}$ LWR reactors are typically refueled every $\sim 18$ months, with $\sim 1 / 3^{\text {rd }}$ of the core changed out at each refueling, so individual fuel assemblies spend $4-5$ years total in the reactor before being changed out.

g Currently this is limited to a portion of the used fuel from Ukraine.
} 


\section{AGREEMENTS AND RELATIONSHIPS}

International trade in reactors and materials in the nuclear fuel cycle involve agreements between countries to allow for trade, followed by agreements and contracts between vendor and customer companies. This chapter discusses these agreements in general terms, and then provides information on reactor vendor/customer pairings and on facilities providing products and services in the fuel cycle.

\subsection{Types of Agreements}

All nuclear trade requires agreements governing how trade will proceed. The nature of nuclear energy and the potential for its misuse necessitates rigorous controls. Peaceful uses of nuclear power are governed first by a number of international treaties and conventions, With the Treaty on the NonProliferation of Nuclear Weapons (NPT) [22] as the underpinning treaty for the global nuclear nonproliferation framework. There are 190 parties to the NPT. The only counties not parties to the NPT are Israel, India and Pakistan. North Korea was a member but withdrew. Countries that join and adhere to these treaties and conventions are then able to engage in more specific arrangements with other member countries.

The Nuclear Suppliers Group (NSG) is part of the nonproliferation framework and was established to develop and implement the Guidelines for nuclear exports and nuclear-related exports through transfers of nuclear-related dual-use equipment, materials and technologies [23]. The current participating governments are: Argentina, Australia, Austria, Belarus, Belgium, Brazil, Bulgaria, Canada, China, Croatia, Cyprus, Czech Republic, Denmark, Estonia, Finland, France, Germany, Greece, Hungary, Iceland, Ireland, Italy, Japan, Kazakhstan, Republic Of Korea, Latvia, Lithuania, Luxembourg, Malta, Mexico, Netherlands, New Zealand, Norway, Poland, Portugal, Romania, Russian Federation, Serbia, Slovakia, Slovenia, South Africa, Spain, Sweden, Switzerland, Turkey, Ukraine, United Kingdom, and the United States.

Another component of the nonproliferation framework is the International Atomic Energy Agency's Safeguards system to include the Additional Protocol. This system of technical measures provides the world with assurance that nuclear material is not being diverted for proliferation purposes.

Other multilateral agreements provides multi-country governance and cooperation such as the Euratom Treaty [24], which created a common nuclear marketplace for members of the European Union, or more commonly bi-lateral agreements between the provider and user countries.

Another form of agreement is a bilateral agreement specific to two countries. In the U.S. the civilian nuclear cooperation agreement, commonly called “123 Agreement” is an example where the U.S. Atomic Energy Act of 1954 requires an agreement be established between the U.S. and another country that defines the legal framework for significant nuclear cooperation with other countries [25]. As the relationship advances, other types of cooperation mechanisms such as "Implementing Arrangements" may be established. For example, in 2014 the United States and Vietnam entered into a 123 Agreement, an Implementing Arrangement was signed in May 2016 to further build on their cooperation in the civil nuclear field. This enhanced cooperation includes collaboration in the following areas build institutional connections enhance and promote public and private training and education, assist with the establishment of an effective regulator, strengthen security, and advance bilateral nuclear trade.

The establishment of these formal government to government agreements on nuclear cooperation provide the environment and legal foundation for individual companies to cultivate relationships in these other countries that can lead to more agreements and contracts with the foreign government or foreign companies, and ultimately for trade to commence.

Before the establishment of nuclear cooperation agreements such as a 123 Agreement in the U.S. and similar types of agreements with other countries, there is typically significant government to government engagement. To begin engagement, less formal mechanisms such as Memorandums of Understanding (MOUs) are established. As cooperation between the two countries deepens, other cooperation 
mechanisms in areas of mutual benefit are established. These types of agreements often expand the relationships. The same pattern is followed at the company level once countries have established relations [26].

The number and type of nuclear cooperation vary in types and level of engagement. Table 1 provides a listing by exporting countries engagement with countries interested in nuclear energy development.

Table 1 - Major Export Countries and Potential Importers

\begin{tabular}{|c|c|}
\hline Exporter/Potential Exporter & Cooperator \\
\hline Canada & Germany, Jordan, Mongolia \\
\hline China & $\begin{array}{l}\text { Algeria, Australia, Bangladesh, Egypt, Ghana, Italy, Jordan, Kazakhstan, Kenya, } \\
\text { Mongolia, Morocco, Namibia, Niger, Nigeria, Oman, Philippines, Saudi Arabia, Senegal, } \\
\text { Sudan, Uzbekistan }\end{array}$ \\
\hline France & $\begin{array}{l}\text { Algeria, Argentina, Australia, Euratom Countries, Brazil, Canada, Chile, Gabon, India, } \\
\text { Japan, Jordan, Kazakhstan, Kuwait, Mexico, Mongolia, Morocco, Namibia, Niger, Saudi } \\
\text { Arabia, South Africa, South Korea, Turkey, United States }\end{array}$ \\
\hline Japan & $\begin{array}{l}\text { Australia, Kazakhstan, Lithuania, Mongolia, Oman, Thailand, Turkey, Uzbekistan, } \\
\text { Vietnam }\end{array}$ \\
\hline South Korea & $\begin{array}{l}\text { Australia, Bangladesh, Egypt, Finland, France, Jordan, Kazakhstan, Kenya, Malaysia, } \\
\text { Niger, Saudi Arabia, Turkey, Ukraine, United Arab Emirates, Uzbekistan }\end{array}$ \\
\hline Russia & $\begin{array}{l}\text { Algeria, Bahrain, Bangladesh, Belarus, Bolivia, Egypt, Indonesia, Italy, Jordan, } \\
\text { Kazakhstan, Laos, Mongolia, Morocco, Myanmar (Burma), Namibia, Nigeria, Poland, } \\
\text { Saudi Arabia, Senegal, Syria, Turkey, United Arab Emirates, Uzbekistan, Venezuela, } \\
\text { Vietnam }\end{array}$ \\
\hline United States & $\begin{array}{l}\text { Argentina, Brazil, Canada, Euratom Countries, India, Indonesia, Kazakhstan, Kenya, } \\
\text { Mexico, Mongolia, Morocco, Oman, Saudi Arabia, South Korea, South Africa, Taiwan, } \\
\text { United Arab Emirates, Uzbekistan, Vietnam }\end{array}$ \\
\hline
\end{tabular}

\subsection{Current Relationships}

One objective of this market analysis activity was to identify the current user/provider relationships. However, a reliable means to systematically identify specific arrangements for fuel services was not identified. The information that is provided is based on news articles and information on supplier web sites. This information has significant shortcomings for several reasons:

- Supplier web sites generally provide only the magnitude of their market share and summaries of the number of companies and countries they support.

- Many suppliers are vertically integrated such that they are their own customers for some of the front-end functions, but not exclusively. Some joint ventures also exist where suppliers share facilities.

- Most fuel arrangements are via long-term contracts which include terms that are not typically disclosed. While spot market prices can indicate general price trends, they do not equate directly to longer-term contract terms. Press release archives on company web sites were found to only go back a year or less.

- Many news articles were for agreements to collaborate on fuel or provide fuel in the future, with few firm dates. Quantities were typically not disclosed, so even though facility capacities were identified, it was not possible to match capacity to individual contracts. The news articles about 
supplying “nuclear fuel” were often not clear about whether fuel assemblies, fuel pellets or just uranium was being supplied.

The best information on fuel arrangements in news reports was found to be associated with new reactor construction, where the news story will usually indicate if fuel is to be provided by the vendor and for how long. The following information for the four South Korean new builds in the UAE was the most detailed and also unusual in the use of multiple vendors for each step [27]:

"Enec ${ }^{\mathrm{h}}$ has now awarded six contracts related to the supply of natural uranium concentrates, conversion and enrichment services, and the purchase of enriched uranium product. The company estimates the contracts are worth some \$3 billion . . . over a 15-year period starting in 2017 . . . Under the contracts, both France's AREVA and Russia's Techsnabexport (Tenex) have been contracted to provide services across the front-end of the fuel cycle, including the supply of uranium concentrates, as well as conversion and enrichment services. Meanwhile, Canada-based Uranium One and UK-based Rio Tinto will also supply natural uranium, the USA's Converdyn will provide conversion services and UK-headquartered Urenco will provide enrichment services. The enriched uranium will be supplied to Kepco Nuclear Fuels - part of Enec's prime contractor consortium, led by Korea Electric Power Corporation (KEPCO) - which will manufacture the fuel assemblies for use in the Barakah plant.”

${ }^{\text {h }}$ Emirates Nuclear Energy Corporation 


\section{THE PLAYERS}

This chapter describes the major operators in nuclear markets. In general there are a small number of suppliers compared to the number of users. The exception to this is the mined uranium market, where there are a larger number of suppliers.

The suppliers are discussed both by country and by the major companies. Some of the major companies are multi-nationals while others are basically extensions of their governments. At the company level, the focus is on the primary or "parent" company. There are a relatively small number of parent companies that cover the primary suppliers but most have multiple subsidiaries. Some subsidiaries companies only exist for a single project or product while others are the local in-country extension of the parent corporation.

\subsection{The Countries}

Table 2 provides a list of countries with some level of involvement with nuclear energy, and also indicates which ones have existing nuclear power plants (NPPs). Countries that do not have NPPs may be listed because they plan to build NPPs soon or because they have current involvement with other parts of the nuclear fuel cycle (e.g. mining). Note that each entry is a hyperlink to the country profile on either the IAEA or WNA web sites. The primary reason for including the table in this report is to provide these country profile hyperlinks, as the profiles can be extensive and are significant sources of information. The lists do not match because the two organizations use different criteria to decide when to include countries that do not have NPPs. For political reasons, IAEA includes Taiwan with China.

\subsubsection{Suppliers}

Seven countries are current providers of reactors for export; Canada, China, France, (Japan/U.S.), Russia, and South Korea. The U.S. is listed together with Japan as the current exports are from U.S. vendors that are either owned by or in business partnerships with Japanese companies. Westinghouse Electric Company is a subsidiary of Toshiba Corporation and GE Hitachi Nuclear Energy is an alliance between General Electric and Hitachi, with the Japanese company called Hitachi-GE Nuclear Energy, Ltd.

Some reactor provider countries are also the primary suppliers of fuel cycle services for export. Some facilities that process materials or fabricate fuels for export are also located in other countries, including Belgium, Germany, Kazakhstan, The Netherlands, Spain, Sweden, and the UK. In addition, many countries with smaller programs have domestic facilities for one or more components of their fuel cycle. There are also a number of pilot or demonstration labs/facilities in countries with smaller programs and in newcomer countries. Lists of non-reactor fuel cycle facilities are provided by function later in this report.

Note that uranium mining/milling is not included in the above discussion and involves several more countries globally. Of the uranium providers without nuclear programs, Kazakhstan is unique in using its market clout as leverage to get a foothold in other areas such as hosting a fuel fabrication facility. The other main uranium supplier without reactors is Australia.

\subsubsection{Users}

All countries with existing nuclear energy programs and nuclear power plants (NPPs) are users of nuclear services, whether domestic or foreign. While smaller countries take pride in their ability to host some parts of their fuel cycles domestically, with few exceptions they rely on others for enrichment and reactor designs. 
Table 2 - Listing of countries with involvement in nuclear energy with hyperlinks to country profiles

\begin{tabular}{|c|c|c|c|c|c|}
\hline$\frac{\text { IAEA List of }}{\text { Countries }}$ & $\frac{\text { WNA List of }}{\underline{\text { Countries }}}$ & $\begin{array}{c}\text { Countries } \\
\text { With } \\
\text { Active } \\
\text { NPPs } \\
\end{array}$ & $\frac{\text { IAEA List of }}{\text { Countries }}$ & $\frac{\text { WNA List of }}{\underline{\text { Countries }}}$ & $\begin{array}{c}\text { Countries } \\
\text { With } \\
\text { Active } \\
\text { NPPs } \\
\end{array}$ \\
\hline Argentina & $\underline{\text { Argentina }}$ & NPP & Mexico & Mexico & NPP \\
\hline Armenia & Armenia & NPP & - & Mongolia & \\
\hline- & Australia & & Morocco & & \\
\hline Bangladesh & Bangladesh & & - & Namibia & \\
\hline Belarus & Belarus & & $\underline{\text { Netherlands }}$ & $\underline{\text { Netherlands }}$ & NPP \\
\hline Belgium & $\underline{\text { Belgium }}$ & NPP & - & $\underline{\text { New Zealand }}$ & \\
\hline Brazil & Brazil & NPP & - & Niger & \\
\hline Bulgaria & Bulgaria & NPP & Nigeria & & \\
\hline Canada & Canada: Nuclear Power & NPP & Pakistan & Pakistan & NPP \\
\hline- & Canada: Uranium & & Philippines & & \\
\hline Chile & & & Poland & Poland & \\
\hline China & China: Nuclear Power & NPP & $\underline{\text { Romania }}$ & $\underline{\text { Romania }}$ & NPP \\
\hline- & $\begin{array}{l}\text { China: Nuclear Fuel } \\
\text { Cycle }\end{array}$ & & $\underline{\text { Russia }}$ & Russia: Nuclear Power & NPP \\
\hline Czech Republic & $\underline{\text { Czech Republic }}$ & NPP & - & Russia: Nuclear Fuel Cycle & \\
\hline- & Denmark & & - & $\underline{\text { Saudi Arabia }}$ & \\
\hline Egypt & & & Slovakia & $\underline{\text { Slovakia }}$ & NPP \\
\hline Finland & Finland & NPP & Slovenia & $\underline{\text { Slovenia }}$ & NPP \\
\hline France & France & NPP & South Africa & South Africa & NPP \\
\hline Germany & Germany & NPP & $\underline{\text { Spain }}$ & Spain & NPP \\
\hline Ghana & & & Sweden & Sweden & NPP \\
\hline Hungary & Hungary & NPP & Switzerland & Switzerland & NPP \\
\hline India & India & NPP & $\begin{array}{l}\text { Syrian Arab } \\
\text { Republic }\end{array}$ & & \\
\hline Indonesia & $\underline{\text { Indonesia }}$ & & - & $\underline{\text { Taiwan }}$ & NPP \\
\hline Iran & $\underline{\text { Iran }}$ & NPP & Thailand & & \\
\hline Italy & Italy & & Tunisia & & \\
\hline$\underline{\text { Japan }}$ & Japan: Nuclear Power & NPP & Turkey & Turkey & \\
\hline- & $\begin{array}{l}\text { Japan: Nuclear Fuel } \\
\text { Cycle }\end{array}$ & & Ukraine & Ukraine & NPP \\
\hline Jordan & Jordan & & $\underline{\mathrm{UAE}}$ & $\underline{\mathrm{UAE}}$ & \\
\hline Kazakhstan & Kazakhstan & & $\underline{\text { UK }}$ & $\underline{\text { UK }}$ & NPP \\
\hline- & Kyrgyzstan & & $\underline{\text { USA }}$ & USA: Nuclear Power & NPP \\
\hline Korea, So. & Korea, So. & NPP & - & USA: Nuclear Fuel Cycle & \\
\hline Kuwait & & & - & $\underline{\text { Uzbekistan }}$ & \\
\hline Lithuania & Lithuania & & Vietnam & Vietnam & \\
\hline
\end{tabular}




\subsubsection{Newcomers}

Both the IAEA and WNA have developed information on countries showing interest in developing nuclear energy programs. The most recent IAEA report on status of nuclear energy [28] indicates that 34 countries $^{i}$ currently without nuclear energy are either "considering, planning, or starting nuclear power programmes”. Of these, 2 had started construction, another 13 either had made a decision or were actively preparing for a decision to proceed, and 19 were in earlier stages of consideration.

The WNA has information on over 50 countries that currently do not have nuclear energy programs, but have expressed some level of interest [29]. This includes some countries that previously had programs that were abandoned. Table 3 and Table 4 below list these countries by region and level of program development, with hyperlinks to the WNA country profiles where available.

While there are a large number of countries on these lists, this is not necessarily an indication of numerous new programs starting in the near future. At any time over the last $50+$ years that commercial nuclear power has existed, a similar list of countries have probably expressed some level of interest or planning. In the next decade, some of the countries in the second and third rows of Table 4 will likely start programs and others may not, while some in lower rows may move up but are less likely to start programs within that timeframe.

Table 3 - WNA list of countries expressing some level of interest developing nuclear power programs

\begin{tabular}{|c|c|}
\hline Region & Countries \\
\hline Europe & $\begin{array}{l}\text { Italy, Albania, Serbia, Croatia, Portugal, Norway, Poland, Belarus, } \\
\text { Estonia, Latvia, Ireland, Turkey }\end{array}$ \\
\hline $\begin{array}{l}\text { Middle East and North } \\
\text { Africa }\end{array}$ & $\begin{array}{l}\text { UAE, Saudi Arabia, Qatar, Kuwait, Yemen, Israel, Syria, Jordan, Egypt, } \\
\text { Tunisia, Libya, Algeria, Morocco, Sudan }\end{array}$ \\
\hline Rest of Africa & Nigeria, Ghana, Senegal, Kenya, Uganda, Tanzania, Namibia \\
\hline Central and South America & Cuba, Chile, Ecuador, Venezuela, Bolivia, Peru, Paraguay \\
\hline Central and Southern Asia & Azerbaijan, Georgia, Kazakhstan, Mongolia, Bangladesh, Sri Lanka \\
\hline Southeast Asia & $\begin{array}{l}\text { Indonesia, Philippines, Vietnam, Thailand, Laos, Cambodia, Malaysia, } \\
\text { Singapore, Myanmar, Australia, New Zealand }\end{array}$ \\
\hline East Asia & North Korea \\
\hline
\end{tabular}

Table 4 - WNA list of newcomer countries by level of progress in developing nuclear power programs

\begin{tabular}{|l|l|}
\hline Level of Progress & Countries \\
\hline Power reactors under construction & UAE, Belarus. \\
\hline $\begin{array}{l}\text { Contracts signed, legal and regulatory } \\
\text { infrastructure well-developed or } \\
\text { developing }\end{array}$ & Lithuania, Turkey, Bangladesh, Vietnam. \\
\hline $\begin{array}{l}\text { Committed plans, legal and regulatory } \\
\text { infrastructure developing }\end{array}$ & Jordan, Poland, Egypt. \\
\hline $\begin{array}{l}\text { Well-developed plans but commitment } \\
\text { pending or stalled }\end{array}$ & $\begin{array}{l}\text { Thailand, Indonesia, Kazakhstan, Saudi Arabia, Chile, } \\
\text { Italy (stalled) }\end{array}$ \\
\hline
\end{tabular}

${ }^{\text {i }}$ The report only mentions 33 countries because it grouped Lithuania with existing programs due to having over 40 years of reactor operating experience, having only recently shut down their last existing reactor (a soviet-era RBMK similar to those at Chernobyl)[107], and planning for a replacement. 


\begin{tabular}{|l|l|}
\hline Developing plans & Israel, Nigeria, Kenya, Laos, Malaysia, Morocco. \\
\hline Discussion as serious policy option & Namibia, Mongolia, Philippines, Singapore, Albania, \\
\cline { 2 - 2 } & $\begin{array}{l}\text { Serbia, Croatia, Estonia \& Latvia, Libya, Algeria, } \\
\text { Kuwait, Azerbaijan, Sri Lanka, Tunisia, Syria, Qatar, } \\
\text { Sudan, Venezuela, Bolivia, Peru. }\end{array}$ \\
\hline Officially not a policy option at present & $\begin{array}{l}\text { Australia, New Zealand, Portugal, Norway, Ireland, } \\
\text { Kuwait, Cuba, Paraguay, Myanmar, Cambodia, Tanzania }\end{array}$ \\
\hline
\end{tabular}

\subsection{Major Companies}

There are hundreds of companies involved with supplying nuclear reactors and fuel cycle materials and services. However, most are subsidiaries of a few larger corporations that are usually partially or fully state-owned or are multi-nationals (or both).

For example, Atomstroyexport is a reactor vendor specializing in export of Russian reactors. It is jointly owned by Atomenergoprom (50.2\%) and Gazprombank (49.8\%). Atomenergoprom also owns reactor operator Energoatom, fuel supplier TVEL, uranium trader Tekhsnabeexport, nuclear facilities constructor Atomenergomash, etc. Atomenergoprom is owned by Rosatom which is a state corporation fully owned by the Russian Federation. To make things more confusing, when building a project in a foreign country many new subsidiaries may be spawned. For the Akkuyu reactor project in Turkey, the "joint stock company” Akkuyu Nuclear JSC was formed, which is owned by - JSC Atomstroyexport, JSC Inter RAO, OJSC Concern Rosenergoatom, JSC Atomtechenergo, JSC Atomenergoremont, and CJSC Rusatom Overseas (the primary shareholder).

Key exporting companies are listed in Table 5, along with the markets they serve. They are described below:

- AREVA is a French-based global company that offers reactors and a full suite of fuel cycle services, including uranium, conversion, enrichment, fuel fabrication for both uranium oxide and mixed oxide fuels, and used fuel reprocessing (returning the products and wastes to the fuel owner). It has offices/operations on 6 continents. AREVA is also involved with a number of joint ventures. They recently sold most of their reactor division to EDF.

- Atmea is a joint venture between AREVA and Mitsubishi Heavy Industries (MHI) offering the ATMEA1 reactor design.

- Cameco is a Canadian-based company that is a global provider of uranium, but also has conversion and PHWR fuel fabrication facilities in Canada. It has mining operations in Canada, the U.S. and Kazakhstan, and owns additional deposits in Australia.

- CANDU Energy Inc. is the commercial reactor division spinoff from Atomic Energy of Canada. It is owned by SNC-Lavalin Inc. It provides CANDU support and offers CANDU new builds.

- ConverDyn is a partnership between Honeywell and General Atomics that markets uranium conversion services.

- Comision Nacional de Energia Atomica (CNEA) is the nuclear energy company of Argentina, providing reactor operations, uranium conversion and PHWR fuel fabrication within Argentina.

- China General Nuclear (CGN) is a large reactor builder and operator in China. They developed the ACPR1000 which was merged with CNNC's ACP1000 to become the Hualong One design.

- China National Nuclear Corp. (CNNC) is the main nuclear company in China providing reactor construction and operation and uranium conversion, enrichment and fuel fabrication. They developed the ACP1000 which was later merged with CGN's ACPR1000 to become the Hualong One design. 
- Department of Atomic Energy (DAE) is the government organization in charge of India's commercial nuclear facilities. Activities include design, construction and operation of PHWRs, heavy water enrichment, uranium conversion, and fuel fabrication within India.

- GE/Hitachi Nuclear Energy is US company formed in an alliance between General Electric and Hitachi, with the Japanese company called Hitachi-GE Nuclear Energy, Ltd. GE/Hitachi designs and provides reactors and also owns or jointly owns fuel fabrication facilities.

- Japan Nuclear Fuel Limited (JNFL) provides uranium enrichment, owns the Rokkasho reprocessing plant, and plans to build a MOX fuel fabrication facility. JNFL is a private company with most of its shares owned by ten Japanese power companies.

- Korea Electric Power Corporation (KEPCO) is the main electrical utility in South Korea and is $51 \%$ owned by the government. KEPCO constructs, operates, and supplies fuel for the domestic fleet of reactors and is now starting to export.

- Mitsubishi Group provides reactor design, construction, and fuel cycle services, primarily through MHI, Mitsubishi Nuclear Energy Systems (MNES) and Mitsubishi Nuclear Fuel Co., Ltd (MNF). They also supply major components, [30] primarily in Japan but also for export. MHI is also in a joint venture with AREVA called Atmea.

- Rosatom is the government-owned parent company of all Russian nuclear energy enterprises. It provides reactor design, construction, operations, and a full suite of fuel cycle services, including uranium, conversion, enrichment, fuel fabrication for both uranium oxide and mixed oxide fuels, and used fuel reprocessing (keeping the products and wastes).

- State Nuclear Power Demonstration Plant Company (SNPDP) is a joint venture (55/45) of State Power Investment Corporation and China Huaneng Group set up to export the CAP1400 reactor.

- Toshiba is a major supplier of reactors and reactor fuels, both its own design and of Westinghouse Electric Company, which it purchased in 2006.

- Westinghouse Electric Company is the designer of the AP1000. It is a U.S. subsidiary of Toshiba.

- URENCO is a major supplier of uranium enrichment services, with facilities in The U.S., UK, Netherlands, and Germany.

In addition to the above list, there are several smaller companies and several government owned facilities that supply fuel materials or services, primarily for domestic use in their respective countries. There are also a number of companies developing advanced reactors and small modular reactors.

\subsubsection{Reactor providers}

The main reactor providers and their primary products for export are listed below. Note that the size of the reactors is approximate and may vary slightly in each installation.

- $\quad$ AREVA/EDF - supplies the European Pressurized Reactor (EPR), a 1,700 MWe PWR designed by AREVA, EDF, and Siemens.

- Atmea - Joint venture of MHI and AREVA, markets the 1100 MWe ATMEA1 PWR reactor, with an agreement to construct 4 in Turkey [31].

- CANDU Energy Inc. - supplies the CANada Deuterium Uranium (CANDU) line of PHWRs. The current design is the 1200 MWe Advanced CANDU Reactor (ACR-1000). 
Table 5 - Primary Export Companies and the Markets They Serve

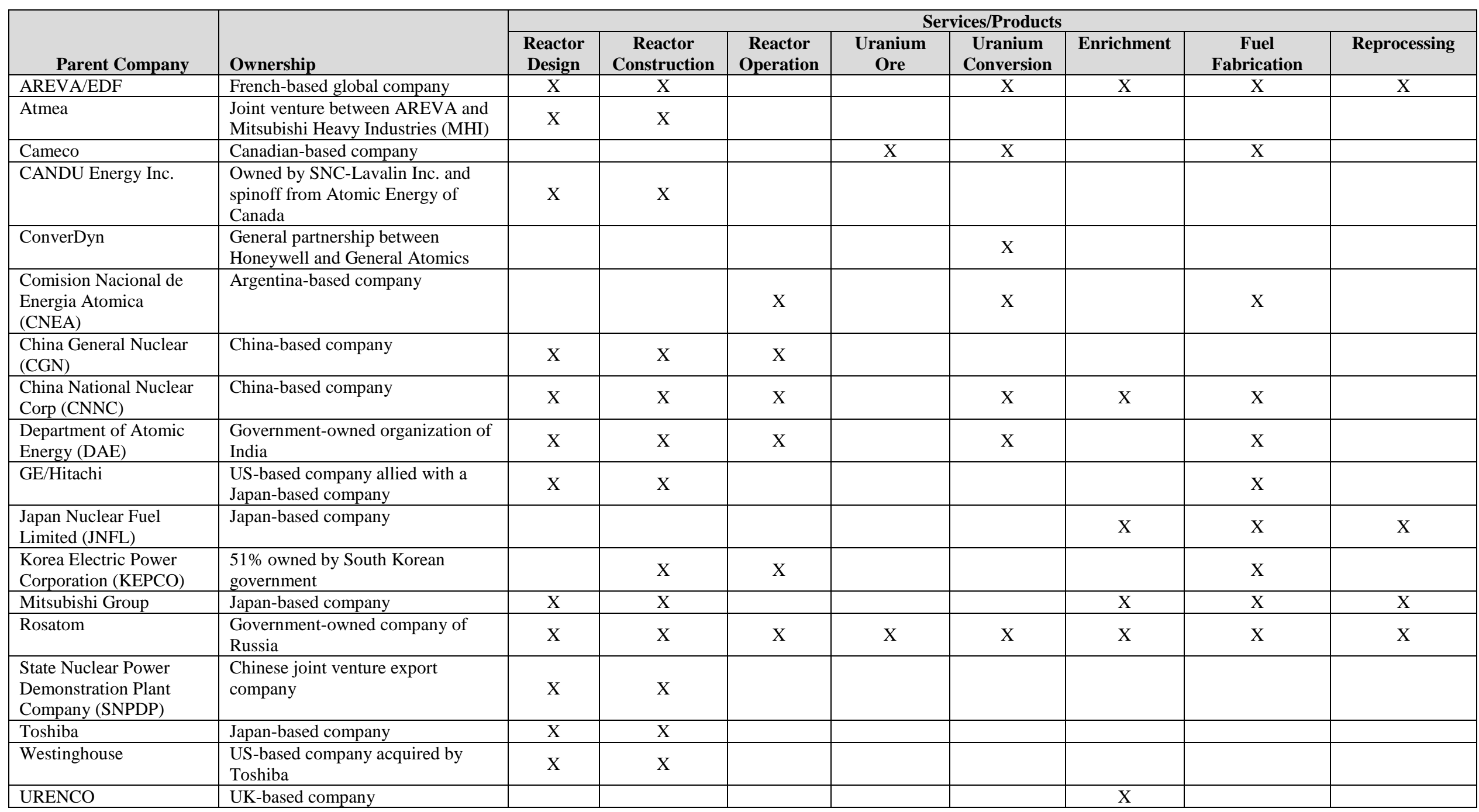


- China General Nuclear (CGN) - Supplies the Hualong One. See Hualong International below

- China National Nuclear Corp. (CNNC) - Supplies the Hualong One. See Hualong International below

- $\quad$ GE Hitachi Nuclear Energy (USA)/ Hitachi-GE Nuclear Energy, Ltd. (Japan) - supplies the 1380 MWe Advanced Boiling Water Reactor (ABWR) and the 1600 MWe Economic Simplified Boiling Water Reactor (ESBWR)

- Hualong International Nuclear Power Technology Co. - 50/50 joint venture of China General Nuclear (CGN) and China National Nuclear Corp. (CNNC) launched in March to market the Hualong One (also known as the HPR1000) [8].

- Korea Electric Power Corporation (KEPCO) - supplies the 1400 MWe Advanced Power Reactor (APR-1400) reactor, a PWR based on the domestic OPR-1000

- $\quad$ Mitsubishi Nuclear Energy Systems (MNES) - marketing the 1590 MWe Advanced Pressurized Water Reactor (APWR), which was planned for the Comanche Peak 3\&4 project that was cancelled

- Rosatom - supplies the VVER family of Russian-designed reactors. The current versions are the 1060 MWe VVER-1000 and the 1200 MWe VVER-1200.

- $\quad$ SNPDP - developing the CAP1400 for export, based on the AP1000 [32, 33].

- $\quad$ Toshiba - Supplies the ABWR (along with GE Hitachi). Supplies the AP1000 through its Westinghouse subsidiary.

- Westinghouse Electric Company (Toshiba) - Supplies the 1200 MWe AP1000 PWR reactor.

Some of these same companies and a number of others are also developing Small Modular Reactors (SMRs) that are not yet ready for deployment. These are discussed in Section 7.2 Near-Term Reactors SMR potential.

\subsubsection{Fuel cycle service providers}

The fuel cycle service provider companies are differentiated by the function being performed. Many are multi-national companies related to reactor vendors. However, some independence is seen in the conversion and enrichment services areas where the products provided are generic and independent of the fuel or reactor design. Some of the fuel fabrication performed by reactor vendors occurs outside their home countries. This may have developed as a local sourcing commitment to reactor customers.

Fuel cycle service providers in Europe have seen some evolution in the form of mergers, buy-outs and facility sales, probably driven by changing market prospects and re-organization of financial stakes as well as changing nuclear energy prospects in their home countries. The net result is some facilities with joint ownership or with contracts to provide local services for vendors from outside the country.

Appendix B-1 provides an extensive list of non-reactor fuel cycle facilities and the current associated companiesj. Most of the parent companies were discussed above in Section 4.2.

j Not listed are PHWR fuel reprocessing facilities in India that are not under international safeguards. 


\section{REACTOR MARKET}

\subsection{Historic Reactor Market Patterns}

The reactor construction market has been driven by four historic themes prior to 2000. These themes are briefly discussed here and also shown in Figure 1. Note that projects finished after 2010 and current projects in progress are not shown, so these graphs do not show current market conditions. This information is presented in more detail and with additional examples in Appendix A-3.

1. Worsening Construction Performance and Waning Public Support - A number of western countries stopped developing their nuclear power programs in the 1980-1990 timeframe due to the interrelated issues of construction delays and cost overruns, declining public support, and safety concerns, as well as slowed or uncertain growth in electricity demand (see Figure 1a). While reactor operators also achieved significantly improved operational performance over the same period, this did not seem to alter public opinion. Some countries are phasing or have phased out their programs (Germany, Italy), while others have paused or intended to cancel their programs with inconsistent policy directions (Spain, Sweden, Belgium, Switzerland). In yet others countries the "nuclear renaissance" resulted in limited new construction (France, U.S. and potentially the UK).

2. Major Geopolitical Event - The political turmoil and negative economic growth in the breakup of the Soviet Union and its Eastern European dependents placed many nuclear power projects in limbo (see Figure 1b). Russia has recovered sufficiently to resume domestic projects at a reduced pace. A large share of domestic nuclear power investment in Russia is intended to replace older units that will be retired. The Russian Federation is now actively pursuing reactor and nuclear fuel exports. Projects to complete reactors in former Soviet bloc countries have varied based on the availability of financing and changing political alignments and interests.

3. Consistent/Improving Construction Performance - Larger nuclear power programs in Asia exhibited a pattern of consistent performance, not experiencing the growing construction delays of their western counterparts (see Figure 1c). These programs in Japan, South Korea and India ${ }^{k}$ never saw a pause prior to 2011, though Japan is experiencing a major disruption now due to Fukushima. Going forward, waning public support and safety concerns may move Japan toward a more restricted program similar to the first bullet above.

4. Rapid Growth and Diversification - More recently, developing countries with rapid energy demand growth and an associated desire to diversify their energy mix have initiated or are considering nuclear energy programs (see Figure 1d). China is the lead in this area, but there are also a growing number of newcomers with similar total energy growth profiles taking the initial steps to start nuclear energy programs. India is also now shifting to this theme, with more rapid nuclear construction planned. Note that China also exhibits consistent construction performance.

\footnotetext{
k India’s project durations have been higher than many other countries, but have seen steady improvement over time.
} 


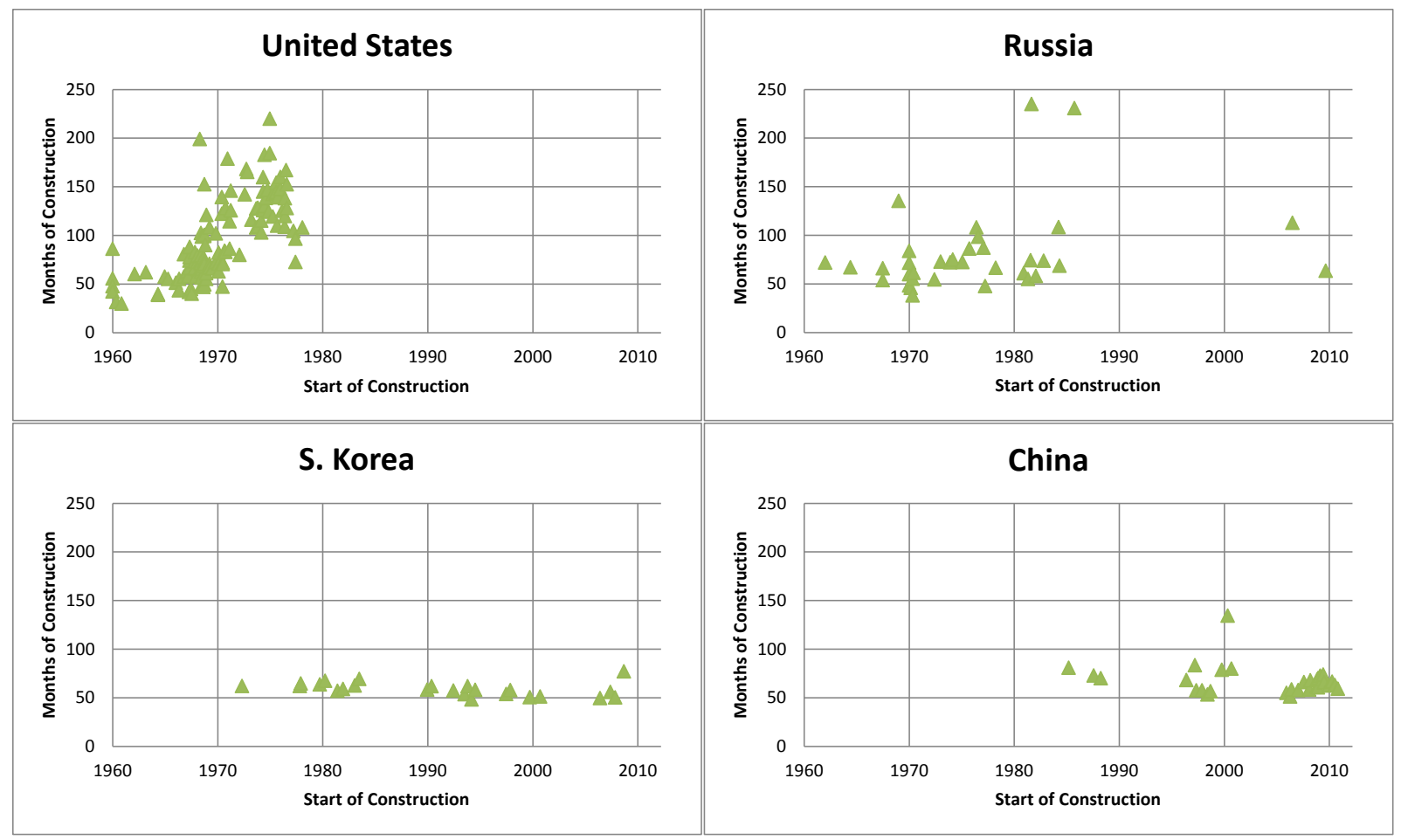

Figure 1 - Reactor construction start year versus duration showing historic themes - a) United States, b) Russia, c) S. Korea, d) China

These historic themes are important in understanding current market behaviors and the drivers behind shifts in market leadership. Rapidly growing programs represent the most vibrant markets for new construction and also indicate growth areas going forward for fuel cycle and operational services. The graphs above provide perspective on why most of the current construction is occurring in Asia. In addition, programs with consistent construction performance are the most likely sources of market leaders going forward, while programs that are stagnant or worsening are more likely to lose current leadership positions. Both South Korea and China are now emerging as new exporters.

\subsection{Current Market Trends}

Current demand for nuclear reactors can be divided into three main groups - countries that are growing rapidly, countries that are maintaining the market share of electricity they have now, and countries that are stalled out or shrinking their programs.

\subsubsection{Accelerating}

Major expansion in China and India - China has 21 reactors (23.8 GWe) under construction ${ }^{1}$ [34], with one or more being finished and one or more being started almost every quarter. An important indicator is construction time, which has averaged 64 months for all reactors started in the last 10 years and connected to the grid by the end of 2015 (18 reactors, $17.2 \mathrm{GWe}$ ). Government projections show 60 GWe of operating nuclear generating capacity by 2021, and up to 150 GWe by 2030 (compared to the current U.S. value of $\sim 100 \mathrm{GWe}$ ). While China is increasing energy generation overall, due to pollution and climate

\footnotetext{
${ }^{1}$ In the first half of 2016, three reactors have been connected to the grid, considered in this report as the end of construction.
} 
change policies they are now placing more emphasis on non-fossil primary energy production and nuclear projections have increased.

India is similar to China with respect to rapidly expanding energy generation and increasing targets for nuclear energy. After decades of isolation, international nuclear trade was reopened in 2008 when India agreed to separate its military and civilian operations and placed its civilian nuclear facilities under safeguards. In 2007, the Prime Minister indicated achieving 20 GWe by 2020 was "modest" and the rate could be "doubled with the opening up of international cooperation" [35]. While the 2020 target will likely not be reached, India has 6 reactors under construction ( $4.3 \mathrm{GWe})$, with another 18 planned. The existing fleet and most of the current construction is composed of smaller PHWRs (up to $700 \mathrm{MWe}$ ), but larger LWRs (1,000 MWe and up) are the majority of the planned plants.

In the longer term India plans for continuing significant nuclear growth, seeking to increase the nuclear share of electricity generation from $3 \%$ to $25 \%$ by 2050 . The approach involves a combination of domestic PHWRs and imported LWRs at 10 sites around the country ${ }^{\mathrm{m}}$. A key ingredient for the LWRs is to attract foreign investment, but this has been slowed by the country's industrial liability laws. These laws were inconsistent with those of most countries as they did not limit liabilities in the case of a nuclear accident, raising the risk for investors. Recent legal changes and ratification of the nuclear liability convention may now open the door for the financing necessary to achieve at least a portion of the desired growth [36].

Korea also growing - Korea's per capita GDP is much higher than China's or India's and power needs are not growing as fast. However, they are planning to increase the nuclear share of electricity. The latest long-term power development plan projects 12 new reactors by 2030, which is an increase of 2 reactors since the last plan [37]. Four reactors have been completed in the last 10 years (average construction time of 58 months) and currently 4 are under construction/startup.

Countries with small existing programs - A surprising number of countries with existing small nuclear programs are planning for expansion (See Table 6). These are countries that are comfortable with nuclear energy based on decades of experience. While the total number of reactors is small, the percent increase in nuclear electricity generation for each country will be large, and illustrates the commitment to nuclear power by these countries. In many cases the new reactors also involve a technology step forward to the larger modern plants typically found in larger programs with assistance from the vendor.

An important gauge of the future of nuclear energy will be how many of these renaissance countries actually follow through on their plans. Many already have reactors under construction, but that is not a guarantee the projects will be finished. For most of those who do follow through, nuclear will become their main source of baseload electricity.

Table 6 - Countries with smaller long-established nuclear programs and plans for expansion

\begin{tabular}{|l|l|l|c|l|}
\hline Country & Current Capacity & Planned Capacity & Capacity Change & Vendor Country \\
\hline Argentina & 2 reactors (935 MWe) & 5 reactors (3.7 GWe) & $4.0 \mathrm{X}$ & China [38], Domestic \\
\hline
\end{tabular}

m “In April 2015 the Indian government gave in principle approval for new nuclear plants at ten sites in nine states. Those for indigenous PHWRs are: Gorakhpur in Haryana's Fatehabad; Chutka and Bhimpur in Madhya Pradesh; Kaiga in Karnataka; and Mahi Banswara in Rajasthan. Those for plants with foreign cooperation are: Kudankulam in Tamil Nadu (VVER); Jaitapur in Maharashtra (EPR); Chhaya Mithi Virdhi in Gujarat (AP1000); Kovvada in Andhra Pradesh (ESBWR) and Haripur in West Bengal (VVER), though this location had been in doubt. In addition, two 600 MWe fast breeder reactors are proposed at Kalpakkam [108].” 


\begin{tabular}{|l|l|l|l|l|}
\hline Armenia & 1 reactor $(375 \mathrm{MWe})$ & 2 reactors $(1.4 \mathrm{GWe})$ & $3.7 \mathrm{X}$ & Russia \\
\hline Brazil & 2 reactors $(1.9 \mathrm{GWe})$ & 3 reactors $(3.1 \mathrm{GWe})$ & $1.6 \mathrm{X}$ & France (German design $)$ \\
\hline Finland & 4 reactors $(2.8 \mathrm{GWe})$ & 6 reactors $(5.7 \mathrm{GWe})$ & $2.0 \mathrm{X}$ & France, Russia \\
\hline Hungary & 4 reactors $(1.9 \mathrm{GWe})$ & 5 reactors $(3.1 \mathrm{GWe})$ & $1.9 \mathrm{X}$ & Russia \\
\hline Mexico & 2 reactors $(1.4 \mathrm{GWe})$ & 4 reactors & TBD & TBD \\
\hline Pakistan & 3 reactors $(690 \mathrm{MWe})$ & 7 reactors $(3.7 \mathrm{GWe})$ & $5.4 \mathrm{X}$ & China \\
\hline Romania & 2 reactors $(1.3 \mathrm{GWe})$ & 4 reactors $(2.7 \mathrm{GWe})$ & $2.1 \mathrm{X}$ & China (Canadian design $)$ \\
\hline Slovakia & 4 reactors $(1.8 \mathrm{GWe})$ & 6 reactors $(2.7 \mathrm{GWe})$ & $1.5 \mathrm{X}$ & Domestic (Russian design) \\
\hline South Africa & 2 reactors $(1.9 \mathrm{GWe})$ & 6 reactors $(6.7 \mathrm{GWe})$ & $3.5 \mathrm{X}$ & TBD \\
\hline
\end{tabular}

Recent nuclear power newcomers - Several newcomers could be significant growth areas in the near future. The UAE has 4 units under construction, while Turkey, Egypt, Nigeria and Vietnam each have 4 or more initial projects in advanced planning. Vietnam originally planned to have construction started by now, but a combination of lower demand growth projections and slow progress in establishing the necessary legal authorities and agencies has delayed the start of projects. Indonesia and Bangladesh are also planning their first reactors, and have huge potential for energy demand growth based on their population sizes, but financing and grid issues may restrain growth. Other recent newcomers have smaller potential, including Belarus (2 plants under construction) and Iran (1 plant operating, 2 more planned).

The growth countries appear to be on a sustainable path, but could be adversely impacted by slower energy demand growth reducing the need for any new generation, a hard economic downturn that impacts the ability to finance large projects, or a significant new nuclear energy related event.

\subsubsection{Maintaining or Stalled}

Russian Federation is actively replacing their aging fleet - Russia currently has 9 reactors under construction or in startup. However, they also have 9 reactors planned for decommissioning by 2023. As the retiring reactors are generally smaller, on net there will be modest growth maintaining market share. They are also actively performing refurbishments and license extensions for much of the remaining fleet.

UK replacement fleet is a developing story - The UK is a bright spot for nuclear construction in Europe. Until just a few years ago, it was unclear how the UK planned to make up generation as their fleet of 18 older gas-cooled reactors reached end-of-life. After renewables appeared to be insufficient to meet demand, the UK has decided to proceed with a new generation of nuclear plants, with 15 in various stages of planning. Last November, the UK Energy and Climate Change Secretary presented the new energy policy, saying about nuclear, "It is imperative we do not make the mistakes of the past and just build one nuclear power station. There are plans for a new fleet of nuclear power stations, including at Wylfa and Moorside. It also means exploring new opportunities like Small Modular Reactors, which hold the promise of low cost, low carbon energy."[39] This is a dynamic situation, with partnerships forming and changing to bid on the available sites the government has identified.

U.S. is mixed, with surprise closures balanced by continued uprates, and limited new construction With five new reactors under construction and some continuing uprates balanced against recent early retirements, the U.S. nuclear capacity is roughly holding even. However, the near future suggests potentially more retirements and nothing new in the construction pipeline. Between the initial and final drafts of this report, the owners of Fort Calhoun, Clinton and Quad Cities 1\&2 announced early 
retirements of those reactors and the owner of Diablo Canyon $1 \& 2$ announced their retirement at the end of their original license instead of applying for a 20 year license extension.

Watts Bar 2 was connected to the grid on June 3 (the first new U.S. reactor in 20 years) and is now undergoing final operational testing, but the four AP1000 reactors under construction have all experience schedule delays and are the focus of much analysis to determine how much of the delays and associated cost overruns are due to these being first-of-a-kind plants ${ }^{\mathrm{n}}$ and how much is systemic and may reoccur in subsequent construction projects. The AP1000 design had a very successful first round of orders (8 reactors), but follow-on order volume will be impacted by the results of these analyses. So far, the AP1000 problems seem smaller than those of AREVA's European Pressurized Reactor (EPR).

The nuclear industry must be evaluated within the bigger economic picture of electricity generation, where plentiful resources have made natural gas the lowest cost producer in many markets, and legislative carve-outs for emissions-free electricity generation have generally been restricted to renewables and left out nuclear. Two factors are of particular importance:

- In restructured markets where generation from intermittent renewables has become significant, nuclear energy has a hard time competing in the volatile hourly electricity pricing. Market share growth in intermittent renewables (wind, solar) is causing much larger hourly and daily imbalances between supply and demand. When intermittent sources are producing, a glut in supply occurs causing depressed (occasional even negative) pricing of electricity for periods of a few hours at a time - too short for nuclear plants to shut down - and when renewables aren't producing and hourly prices jump, then fast reaction natural gas peaking plants garner most of the added revenue. Note that renewables still can make money even when prices are depressed (even negative), as long as their \$23/MW-hr production tax credit and other incentives provide enough revenue to offset their operational costs and any negative pricing costs. Grid regulators are looking at pricing models that give more value to baseload generation, but suppliers of electricity from renewables and natural gas are fighting these changes because the current system is working well for them.

- Renewable portfolio standards (RPS) provide renewables with a guaranteed market share that will increase significantly in the future. Currently, 29 states have renewable portfolio standards ${ }^{\circ}$ which require a growing portion of total electricity to come from these sources [40, 41]. This skews the markets in these states in two ways, both detrimental to nuclear power. First is the direct mandate for renewables, which is additive with existing federal production tax credits and other incentives. Second, most growth in renewables is in intermittent renewables (wind, solar) which require backup power, giving a coupled advantage to natural gas plants with their ability to quickly ramp up generation. Since overall U.S. electricity growth is less than $1 \%$ annually, achievement of the guaranteed renewable market shares and their coupled natural gas back-ups require other generation to be pushed aside, independent of price.

\footnotetext{
${ }^{\mathrm{n}}$ These projects are first-of-a-kind on several dimensions, including the first plants built under the new combined construction and operating license regulatory approach, the first of this Generation III+ design built in the U.S. (and concurrent with the first globally), and the first reactors constructed in the U.S. using factory fabrication of large modules instead of primarily on-site construction.

${ }^{\circ}$ The Database of State Incentives for Renewables \& Efficiency (DSIRE) provides detailed information on specific policies and incentives - http://www.dsireusa.org/
} 
In the medium term, some nuclear plants will be reaching the end of their current 20 year license extensions ${ }^{\mathrm{p}}$, but there is an ongoing effort to look at a second round of license extensions to 80 years with Surry and Peach Bottom likely to be the first applicants [42]. Many plant owners have already replaced major components such as steam generators to improve plant output and extend plant life.

Canada has been refurbishing, but future direction unclear - A significant portion of the Canadian fleet has undergone a prolonged refurbishment effort over the last 20 years that is now mostly complete and has extended the life of the reactors. To date this has included four Bruce units, two Pickering units [43] and Point Lepreau. Three units were closed instead of going through refurbishment (Gentilly 2 and two Pickering units). A new round of rolling refurbishments for six Bruce units is planned beginning in 2020. No new reactors are currently under construction, and 4 planned units are currently deferred.

France is planning for zero growth, which will result in declining market share - France has one unit under construction with significant delays. The current government strategy is to allow growth in nonnuclear generation to bring the nuclear component down from $~ 75 \%$ of electricity production to $50 \%$ while also requiring any new reactors to be offset by closure of older reactors [44]. This will increase energy diversity and allow room for more renewable generation. Like the U.S. and Canada, France is facing the need in the medium term to replace aging units or replace major components to enable life extensions. Public reaction to the aesthetics and cost of renewables may be a developing factor for nuclear futures in the mid-term.

Japan seeing limited restarts - Nuclear futures in Japan continue to be uncertain. Sentiment hit bottom following Fukushima, and there was talk of abandoning nuclear power completely. Nuclear futures are beginning to turn around, with Sendai- $1 \& 2$ plants restarted ${ }^{\mathrm{q}}$ and several more projected [45] and the planned nuclear share by 2030 to be $20-22 \%$ (versus 30\% prior to the accident) [46].

Japan's longer term growth is still not certain, and the most recent government approved electricity generation plan has nuclear at $20-22 \%$ of total electricity, down from $\sim 30 \%$ before Fukushima. ${ }^{r}$ While over half of the existing reactors have asked for permission to restart, the regulatory review has only been completed on a handful and approval for restart must be obtained at multiple government levels. To date, only 2 have resumed continuous operation, while two others were briefly restarted, then halted again by legal challenges [47]. Some have also been identified for decommissioning. There have been no new construction starts since Fukushima, but construction has resumed at the plants that were under construction at the time of the accident. To achieve and maintain the $20-22 \%$ energy mix after factoring in current plants that may be decommissioned may require resuming the slow but steady growth of the past. However, uncertainty remains high and more time is needed for the nuclear program to stabilize.

Spain backed away from close-out - In 1984, Spain passed a law placing a moratorium on new builds and limiting existing reactors to 40 years of operation. However, rising costs of incentives for renewables have resulted in legal changes in 2011 and a number of license extensions have been granted. Spain has 7 plants operating and another in refurbishment and expected to restart soon.

For the above countries, economics and the availability or lack of fossil alternatives appears to be the main drivers, though sometimes for different reasons. Russia wants to sell its oil and gas, which more

${ }^{\mathrm{p}}$ Reactor licensing in the U.S. includes an initial operating license for 40 years, followed by 20 year extensions. With few exceptions, owners have filed for extensions to 60 years when their current licenses were nearing their end or when a major uprate was undertaken. To date none of these initial extensions have been rejected.

q Takahama-3\&4 were also briefly restarted, then halted again[47]

${ }^{r}$ See "Post-Fukushima energy policy changes, 2011" in the WNA country profile at http://www.world-nuclear.org/informationlibrary/country-profiles/countries-g-n/japan-nuclear-power.aspx 
domestic nuclear enables, and domestic labor is still relatively cheap. The UK is looking to maintain energy diversity while meeting $\mathrm{CO} 2$ reduction goals. Spain is reacting to the cost of incentivizing renewables. The U.S. and France are reacting to the rising costs of domestic nuclear projects, even while the growth countries seem to be able to build the same plants faster and more economically. Japan remains energy poor and as they recover from the Fukushima-driven shutdowns, they are finding the options have not changed.

Additional Newcomers - Several additional countries have plans to start nuclear power programs that are less definite, including Chile, Indonesia, Jordan, and Kazakhstan. Multiple others are considering, but are far from execution. (A full list of the probable and possible newcomers was provided in Section 4.1.3.) The main inhibitors appear to be financing and inadequate grid systems, along with the effort required to set up the necessary institutions.

\subsubsection{Phase-out}

Germany, Belgium still on phase-out path - Germany and Belgium were both on phase-out paths, then changed plans, and then changed again. Germany had originally planned on phase-out after a government change in 1998, then cancelled the policy with a new government in 2009, but reinstated it in 2011. Germany has shut down 10 reactors since 2003.

Belgium's strategy has swung with changes of government to consider extension of current plants to retaining the 40 year limitation originally passed in 2003. The prohibition against new plants passed in 2003 has remained in force throughout the other changes. However, unlike Germany no plants have actually been retired since the policy was put in place. More recently, an additional operating life of 10 years was granted for the Belgian plants given underperformance in renewable energy deployment. A recent International Energy Agency review of Belgium critiqued the lack of a long-term energy policy, specifically siting the impact of the nuclear phase-out [48].

Both countries have also imposed new taxes on nuclear production to help pay for expansion of renewable energy.

Sweden policy mostly negative, public opinion mostly positive - Sweden is currently operating nine reactors (9 GWe). After Three Mile Island, Sweden had a referendum on phase out of nuclear energy that resulted in a policy of operating current and under construction plants through end-of-life with no new construction. In 2010, this was modified to allow replacement construction at existing sites, but in October 2014 phase-out was again being implemented, even though less than a quarter of the population supports the position. On June 10, this position was again reversed when the government struck a deal with the opposition to allow replacement of existing reactors as they reach the end of their economic lifespans while abolishing the energy tax paid by nuclear energy producers [49]. The government imposes significant taxes and regulations on nuclear energy while providing significant incentives for renewables.

Italy remains phased-out - Italy closed out its 4 reactor nuclear fleet following Chernobyl, with the last two plants shut down in 1990. There was considerable interest in reversing this decision due to high electricity costs, and a referendum was scheduled for June, 2011. The timing of the Fukushima accident in March 2011 contributed to the nuclear power plan being rejected in the referendum.

For these close-out countries, the general drivers are fear of accidents and lack of geologic disposal options. Economics actually appears to be a reason to continue with nuclear, since the alternative is renewables and the cost of subsidies continues to climb as they gain mandated market share. Successful builds in Asia and in closer small renaissance and newcomer countries and success in opening a geologic repository in Finland are probably both needed to soften positions. 


\subsection{Current Demand}

As of June 2016, 62 nuclear power reactors are under construction globally, with five more in different stages of start-up. A summary of these projects are provided here, while additional information on these projects is provided in Appendix 0. Reactor capacities are gross rated generation.

- Argentina - CAREM Prototype (29 MWe)

- Belarus - 2 Russian VVERs (1100 MWe each)

- Brazil - 1 PWR in collaboration with AREVA (1245 MWe)

- China - 20 large PWRs, mostly domestic but includes 4 AP1000s (MHI/Westinghouse), 2 EPRs (AREVA) and 2 VVERs (Rosatom), 1 prototype high temperature gas reactor (HTGR), plus 3 PWRs in start-up

- $\quad$ Finland - 1 EPR (1720 MWe)

- $\quad$ France - 1 EPR (1750 MWe)

- India - 4 domestic PHWRs (700 MWe each), 1 VVER (1000 MWe), 1 prototype fast breeder reactor (FBR) (500 MWe)

- Japan - 2 domestic BWRs ( 1350 MWe each)

- $\quad$ South Korea - 3 domestic APR-1400s (1400 MWe each), plus one in start-up

- Pakistan - 4 Chinese PWRs (2 at 340 MWe each, 2 at 1150 MWe each)

- Russia - 6 VVERs ( 1100 MWe each), 2 prototype floating reactors (70 MWe each), plus one prototype FBR (880 MWe) in start-up

- Slovakia - 2 VVERs (471 MWe each)

- Taiwan - 2 General Electric BWRs (1300 MWe each), construction suspended ${ }^{\mathrm{s}}$

- UAE - 4 KEPCO APR-1400s ( 1350 MWe each)

- U.S. -4 AP1000 ( 1150 MWe each), plus one resumed Westinghouse PWR (1200 MWe) in start-up,

Table 7 provides a summary of the new construction of reactors by vendor, omitting non-traditional prototypes (CAREM, HTGR, FBRs, and floating reactors). Both total market share and export market share are shown ${ }^{\mathrm{t}}$. While China has the largest share of total construction, most is domestic. Construction in China is $60 \%$ domestic and $40 \%$ imports. Indian companies dominate domestic construction, but India has agreements with several foreign reactor vendors to build in India (U.S., France and Russia). Rosatom

\footnotetext{
${ }^{\text {s }}$ Public support for nuclear power in Taiwan has eroded since Fukushima. Construction on Lungmen-1 is complete and it passed preoperational testing in August, 2014, but is now sealed for 3 years until a public referendum can occur. Lungmen-2 construction is more than $90 \%$ complete but also suspended for 3 years.

http://www.taiwantoday.tw/ct.asp?xItem=232105\&ctNode=2182

http://www.world-nuclear-news.org/NN-Political-discord-places-Lungmen-on-hold-2804144.html

t Total market share was determined by dividing the NPPs the Total. Export market share was determined by dividing the Export NPPs by the Export Total.
} 
is the largest exporter (by one reactor) and also has a monopoly on domestic construction.

KEPCO/DOOSAN also has a domestic monopoly at this time. Japan and the U.S. vendors are currently dominated by domestic companies, if Toshiba-Westinghouse and the GE-Hitachi partnerships are considered domestic for both countries.

Table 7 - Market shares of new LWR/PHWR reactor construction by vendor

\begin{tabular}{|l|c|c|c|c|}
\hline Company/Country & NPPs Total & Share & Export NPPs & Export Share $^{\mathrm{u}}$ \\
\hline All China & 16 & $28 \%$ & 4 Pakistan & $17 \%$ \\
\hline Rosatom & 11 & $19 \%$ & 2 Belarus, 2 China, India, & $22 \%$ \\
\hline Toshiba/Westinghouse & 8 & $14 \%$ & 4 China & $17 \%$ \\
\hline KEPCO/DOOSAN & 7 & $12 \%$ & 4 UAE & $17 \%$ \\
\hline AREVA & 5 & $9 \%$ & Brazil, 2 China, Finland & $17 \%$ \\
\hline India & 4 & $7 \%$ & & $9 \%$ \\
\hline GE-Hitachi & 4 & $7 \%$ & 2 Taiwan & \\
\hline Slovakiaw & 2 & $3 \%$ & & $99 \%$ \\
\hline Total (\% due to rounding) $^{w}$ & 57 & $99 \%$ & 23 & \\
\hline
\end{tabular}

Over 400 additional reactor projects are in various stages of planning or speculation. Appendix B-3 provides information on $\sim 160$ of those projects that seem the most active or have made the most progress in selecting sites and designs or in seeking regulatory approval. However, some of these projects are currently stalled, as exhibited by the planned construction year having already passed, and some are not as far along, as exhibited by a lack of construction year, unknown reactor type, etc. Compilation of this list was very subjective, as many projects have been proposed and not gone anywhere, others made significant progress but are now stalled, while others seem less mature but are currently moving forward. For example, the planned projects in the U.S. cover both projects that have sought NRC licensing or early site permits in the last decade but are now stalled or simply "banked" by utilities ${ }^{\mathrm{x}}$, as well as some new, less mature projects that are working on securing local approvals but have not yet applied to the NRC. If only those projects currently moving forward were included, the U.S. list would only have a few entries.

The identified customers and suppliers for current and planned reactors (listed in Appendices 0 and B-3 and [50]) are summarized in Table 8.

\footnotetext{
${ }^{u}$ For China and India, multiple companies are grouped.

${ }^{v}$ In developing the export market share, Toshiba/Westinghouse and GE-Hitachi/ Hitachi-GE were considered to be both Japanese and U.S.

${ }^{\text {w }}$ Completion of a Russian design using mostly domestic companies.

${ }^{\mathrm{x}}$ Due to the long permitting time in the U.S., some utilities have decided to get sites or projects preapproved to allow them to move forward more quickly if/when local market conditions become favorable for new builds.
} 
Table 8 - Supplier countries and reactor vendors for current and likely construction projects

\begin{tabular}{|c|c|c|}
\hline Customer Country & Supplier Country & Vendor \\
\hline Argentina & China & CNNC \\
\hline Armenia & Russia & Rosatom \\
\hline Bangladesh & Russia & Rosatom \\
\hline Belarus & Russia & Rosatom \\
\hline Brazil & Germany (but built by France) & Siemens \\
\hline China & China, France, Japan, Russia & CNEC, CNNC, DEC, AREVA/EDF, MHI/WH, Rosatom \\
\hline Egypt & Russia & Rosatom \\
\hline Finland & France, Russia & AREVA, Rosatom \\
\hline Hungary & Russia & Rosatom \\
\hline India & India, Russian, France, U.S. & HCC, BHEL, Rosatom, EDF, GE-Hitachi, Westinghouse \\
\hline Iran & Russia & Rosatom \\
\hline Japan & Japan & Hitachi-GE \\
\hline Jordan & Russia & Rosatom \\
\hline Kazakhstan & Russia & Rosatom \\
\hline Pakistan & China & CZEC, CNNC \\
\hline Romania & Canada (but built by China) & Apparently Candu Energy, constructed by CNPEC \\
\hline Russia & Russia & Rosatom \\
\hline Slovakia & Russia & Rosatom \\
\hline South Africa & Probably Russia & Probably Rosatom \\
\hline South Korea & South Korea & DOOSAN \\
\hline Turkey & Russia, France/Japan & Rosatom, MHI \\
\hline UAE & Korea & KEPCO \\
\hline Ukraine & Russia? & Rosatom? \\
\hline UK & France, China, Japan/US, Canada? & Still sorting out \\
\hline U.S. & U.S., France & Westinghouse, AREVA, Nuscale \\
\hline Vietnam & Russia, Japan & Rosatom, Westinghouse \\
\hline
\end{tabular}




\subsection{Demand Drivers}

Looking forward, several factors will impact the demand for new reactors.

- High energy demand is a driving factor for construction of new generating facilities, including additional nuclear facilities in countries such as China and India that already have a nuclear program. Current newcomer countries and many potential newcomer countries also have high energy demand. Nuclear power is generally not the initial energy generation technology deployed in high demand countries, but instead is added later to improve baseload generation and increase energy diversity.

- Financing is a key component of all reactor construction projects going forward. The Organisation for Economic Co-operation and Development (OECD) Arrangement on Export Credits [51] provides guidelines for participating countries ${ }^{\mathrm{y}}$ for financing of nuclear projects, including finance terms (interest rates, load durations, etc.). Reactor export countries that are not part of this arrangement may offer more favorable financing terms, providing a competitive advantage. Rosatom has had an advantage in this respect with the ability to obtain governmentbacked financing for their export business. Their web site lists funding through export loans, public loans for the Russian Federation, funding from public banks in Russia, and joint ownership agreements [52]. However, with the current budget problems in the Russian Federation, this approach could become more difficult for new projects going forward due to changes in Rosatom's governmental support [53]. This in turn may slow some newcomer countries such as Bangladesh, Egypt, Jordan, Nigeria, and Vietnam, who are looking to Russian financing for their first nuclear power plants. China also has the ability to provide government-backed financing outside of the OECD guidelines.

- Another key ingredient for export is successful completion of early projects. Project delays impact not just the image of a vendor, but also potentially their financial health and the ability of their potential customers to obtain financing for projects that include their designs. Some leading projects that have had or are experiencing schedule difficulties include:

o Kudankulam-1\&2 - Initial Rosatom VVER project in India

o Taishan 1\&2 - Initial AREVA EPR project in China

o Sanmen-1\&2 - Initial Mitsubishi/Westinghouse AP1000 project in China

o Olkiluoto-3 - Initial AREVA EPR project in Finland

In the case of AREVA, the financial difficulties have resulted in the sale of the majority of their reactor division to EDF [54] and with EDF taking over AREVA-initiated projects in India [55] and the UK.

On the other hand, the ambitious 4-reactor KEPCO project in the UAE (Barakah-1-4) appears to be maintaining schedule. If completed on time, this would likely give KEPCO an advantage in negotiating new export projects elsewhere.

- On the demand side, the slowdown of the economy in China may affect both demand growth and the ability to finance new construction projects. Recent announcements of 1.8 million layoffs in the coal and steel industries seem to indicate that China may be starting a new round of

y Participating countries include Australia, Canada, the European Union, Japan, Korea, New Zealand, Norway, Switzerland, and the United States. 
restructuring similar to the reforms of the 1990s [56]. So far, the nuclear industry has not been impacted, and it may be given immunity as China tries to reduce pollution caused in part by heavy energy sector reliance on coal.

- Reactor replacement will also be a driver going forward. According to the IAEA's Power Reactor Information System, the median age of the global reactor fleet is just over 30 years, with the oldest at 47 years. Russia has been building replacement VVER reactors as older RBMK reactors are retired. The UK is planning for new PWRs to replace aging GCRs. Other countries are extending the life of current reactors or planning for phase-out.

\subsection{Supplier trends}

\subsubsection{Emerging suppliers}

The traditional suppliers of nuclear technology are being challenged by the growth countries as they develop more experience and capabilities and start to market designs for export. Successful learning in recent construction and operation of reactors and the ability to construct the same reactor design multiple times are leading to reduced costs and reduced project risks, which in turn will make financing easier. In the near term, the ability to finance will be a key in attracting additional customers.

The Korea - UAE deal was the first hint of what is likely coming from Korea and China and eventually India. When UAE first started looking for a reactor vendor, the competition seemed to involve the traditional powerhouses, but KEPCO came in with a low bid and won the contract. A similar pattern occurred when the Czech Republic cancelled an open procurement action for two reactors in 2014 due to cost concerns $[57,58]$, then suggested they would restart the process. The bidders on the first procurement were all traditional vendors (Rosatom, AREVA, and Westinghouse), while both South Korea and China expressing interest in bidding if the procurement resumed.

These countries are not yet ready to compete in fuel cycle services, though that may also come soon.

Russia is still the supplier of choice for countries with close political ties, but is also emerging as the supplier of choice for newcomers who need financial assistance. However, this could change as China uses its financial strength and current construction experience to develop its export business.

\subsubsection{Struggling suppliers}

Some traditional suppliers are struggling, at least as reactor vendors. AREVA has seen a significant change of fortune due primarily to delays in their flagship EPR projects, quality control issues, and other underperforming investments during the last decade. The losses there are impacting the ability to update and expand fuel services. Fuel facility replacement projects in France have recently been completed or are going forward (Georges Besse II, Comerhex II), but expansion projects elsewhere have been put on hold (Eagle Rock). Weak global demand for fuel services is also a current challenge.

Traditional U.S. companies Westinghouse and GE had suffered too long from the domestic construction drought and were bought up or had to form joint ventures with firms in Japan. For Westinghouse, issues with the initial AP1000 projects have not been as significant as for the EPR, but none are operating yet. As current projects are completed and the AP1000s enter operation, the level of second-round sales will be a strong indicator of the strength of the design. The GE-Hitachi reactors have not been as successful in gaining sales. For both companies, the fuel service businesses remain healthy, but GE-Hitachi is not as well positioned to benefit from the growth in China and India.

\subsubsection{Partnering arrangements}

Due to the cost of nuclear projects, partnering is common on the buyer side. On the seller side, the international nature of the business results in partnerships forming and dissolving. The posturing for business in the UK produced some examples: 
- Electricite de France teaming with China General Nuclear Power for Hinkley Point C in the UK,

- GE Hitachi and Spain's Iberdrola partnering on the offer to build PRISM reactors in the UK

- Westinghouse taking over the Springfields Fuel site in the UK after Cameco allowed long-term contracts with the facility to run out

- Spains’s Iberdrola, Frances’s ENGIE (formerly GDF Suez), and Scottish and Southern Energy (SSE) jointly purchased options on a site near Sellafield for future reactor construction in 2009, with SSE bought out be the other two partners in 2011. In 2013, Westinghouse purchased Iberdrola's share.

- A Westinghouse-founded company, Nuclear Power Delivery U.K. establishing agreements with Rolls-Royce, BAE Systems, and Doosan Power Systems

Some companies from close-out countries with a long nuclear history seem to be determining how to adjust. Siemens is an example:

- Ended a joint venture with AREVA in 2009,

- Moved to team with Rosatom in 2010

- Announced it was leaving the nuclear industry in 2011. 


\section{FUEL CYCLE SERVICE MARKETS}

Demand for services mostly follows demand for reactors, but there are some differences. First, as programs evolve, they tend to develop more domestic capabilities. Second, some countries are changing fuel fabrication suppliers or trying to develop multiple suppliers. Third, countries that have changed their nuclear strategies may need to adjust their services to match. For example, a country that is stalled or in closeout will need fewer reactor construction and support services but will likely need more decontamination and decommissioning workers.

Fuel cycle services are primarily driven by the installed base of reactors. Historically, PHWRs required no uranium enrichment, though Canada has been developing reactors that run on very low enrichment uranium (less than $2 \%{ }^{235} \mathrm{U}$ ). PHWRs can also use uranium recovered during reprocessing of LWR fuels without re-enrichment. Due to the low burnup of unenriched fuels, PHWRs require a frequent supply of fuel and produce a high volume of spent fuel. GCRs and RBMKs use some enrichment (up to 3.5\%), but are also refueled frequently. LWRs currently use enriched uranium in the 4-5\% range and have batch refueling of typically $1 / 3^{\text {rd }}$ of the core every 12 to 18 months.

Enrichment significantly impacts the dynamics of the fuel cycle front end because, due to a combination of proliferation concerns ${ }^{\mathrm{z}}$ and economies of scale ${ }^{\text {aa }}$, it is only performed at a limited number of facilities worldwide. Enrichment also requires conversion of natural uranium oxide $\left(\mathrm{U}_{3} \mathrm{O}_{8}\right)$ into uranium hexafluoride $\left(\mathrm{UF}_{6}\right)$. Conversion is a chemical process that efficiently operates at scales that are large relative to demand and therefore few facilities are needed to support demand. This results in the uranium flow from a large number of mines being focused to the few conversion and enrichment facilities before moving on to the fuel fabrication facilities.

Fuel fabrication capacities for both natural uranium oxide fuels for PHWRs and enrichment uranium oxide fuels for LWRs are well above needs globally. However, unlike the fungible products of the earlier stages in the fuel cycle, fuel fabrication is highly specialized for specific fuel designs. The trend in the PHWR fuels area is toward each user developing some domestic capacity to meet needs, with the balance made up primarily by Canada.

For the LWR fuels, demand in Europe is stagnant and will be dropping due to phase-out in some countries, while demand in Asia is shifting due to reactors shut down in Japan and new reactors being completed in China and Korea. To increase flexibility, larger vendors are starting to collaborate/compete, with the goal of being able to fabricate multiple fuel designs. Direct licensing of a fuel design is one approach for fabrication of fuels from another vendor. Another approach is for one vendor to purchase a portion of another vendor or enter into a joint venture. If the owner of the fuel design is not willing to license the design or enter into a joint venture, the final approach is to obtain regulatory approval to replace the reactor vendor fuel with fuel of another design that is compatible with the reactor. This is the approach being taken in Ukraine by Westinghouse [59], using fabrication facilities they own in Sweden.

\footnotetext{
${ }^{\mathrm{z}}$ Nuclear weapons are constructed from highly enriched uranium or separated plutonium. Thus enrichment and reprocessing (chemical separations) plants are two facilities of concern for nuclear proliferation. As part of the international safeguards system, the International Atomic Energy Agency regularly inspects civilian enrichment and reprocessing facilities and monitors the movement of materials through them.

aa Enrichment facilities are massively modular at the equipment level, with thousands of identical centrifuges in a typical facility. Smaller facilities are at an economic disadvantage.
} 


\subsection{Fuel Cycle Status}

\subsubsection{Uranium}

This assessment has not attempted to assess uranium mining and milling due to the numerous mines globally. A large number of counties have uranium mines. The majority of uranium production in 2015 was in Kazakhstan (39\%), Canada (22\%), and Australia (9\%). A database of existing and near-term uranium mines was developed in 2011 and a 12 page listing of mines is available on request [60]. A more up-to-date source is the Uranium Suppliers Annual, which can be purchased from UX Consulting Company ${ }^{\mathrm{bb}}$.

The trend in uranium extraction has been to move away from deep rock mining and instead concentrate on open pit mining of near-surface deposits (especially when uranium is a byproduct of extraction of another element) and in-situ recover mining (ISR). Kazakhstan is the current lead producer of uranium and uses ISR extensively. The Olympic Dam copper mine in Australia is the largest single uranium resource in the world, where uranium recovery is a byproduct of copper production.

Uranium is typically available to any nuclear program that has agreed to IAEA safeguards and the guidelines of the Nuclear Suppliers Group, but typically requires a nuclear cooperation agreement between the exporting and importing countries. Uranium trade between India and members of the Nuclear Suppliers Group was stopped in 1974 due to India's military use of nuclear energy. During this period, some Indian reactors were sometimes forced to run at reduced power to preserve fuel. Once India agreed to separate its military and civilian nuclear facilities and bring the civilian facilities under safeguards, the ban was lifted in 2008 and the major producers quickly established trade [61, 62, 26, 63, 64, and 65].

\subsubsection{Conversion}

Table 9 lists the main uranium conversion facilities for making $\mathrm{UF}_{6}$. Not listed are facilities for making unenriched uranium oxide used in PHWRs. Note that different sources often quote different capacities for these facilities. The UK facility lease recently changed hands and while Westinghouse UK indicates they have the ability to produce $\mathrm{UF}_{6}$, it was not clear if the facility had resumed operations or was in standby status. Total capacity is well above the IAEA estimated demand of $\sim 46,000 \mathrm{t} \mathrm{HM/yr}$ (plus an estimate 12,000 t HM/yr from secondary supplies) and comfortably above the WNA estimated demand of $\sim 65,000$ tonnes [66], of which $~ 94 \%$ is used in LWRs and required conversion and enrichment.

Since 2005, the spot price for conversion has traded in a range of \$6-\$13 per $\mathrm{kg} \mathrm{UF}_{6}$ with recent prices near the low end of the range. ${ }^{c c}$ This includes a period when the U.S. facility (Metropolis) had an extended outage for unexpected repairs, indicating prices are not that sensitive to supply capacity. Reactor owners and fuel vendors know their needs well in advance, so these plants are assumed to primarily work via long-term contracts. The customers for these facilities are the uranium enrichment plants.

\footnotetext{
bb Available at https://www.uxc.com/p/products/pdf/Flier-USA\%202015-12.pdf

cc Information on long-term trends in uranium, conversion, and enrichment (SWU) spot prices is available in graphical form at https://www.uxc.com/p/prices/UxCPriceChart.aspx?chart=spot-u3o8-full
} 
Table 9 - Information on current global conversion facilities

\begin{tabular}{|c|c|c|c|c|c|}
\hline $\begin{array}{c}\text { Host } \\
\text { Country }\end{array}$ & Facility Name & $\begin{array}{c}\text { Facility Status } \\
\text { (As of } 9 / 2 / 2015 \text { - } \\
\text { IAEA) }\end{array}$ & $\begin{array}{l}\text { Design } \\
\text { Capacity }\end{array}$ & Owner & Operator \\
\hline Argentina & Pilcaniyeu Conversion Facility & In operation & 62 t HM/year & $\begin{array}{l}\text { CNEA - } \\
\text { Argentina }\end{array}$ & CNEA - Argentina \\
\hline Canada & Cameco - Port Hope (UF6) & In operation & 12500 t HM/year & Cameco & Cameco \\
\hline China & Lanzhou & In operation & 3000 t HM/year & CNNC - China & CNEIC - China \\
\hline France & $\begin{array}{l}\text { Comurhex II - Pierrelatte } \\
\text { (UF6) }\end{array}$ & $\begin{array}{l}\text { Under } \\
\text { construction }\end{array}$ & 15000 t HM/year & AREVA NC & COMURHEX - France \\
\hline France & Comurhex Pierrelatte (UF6) & In operation & 14000 t HM/year & AREVA NC & COMURHEX - France \\
\hline Russia & Seversk & In operation & 12000 t HM/year & TVEL - Russia & JSC SCC - Russia \\
\hline UK & Springfields Line 4 Hex Plant & Stand by & 5000 t HM/year & NDA - UK & WH - UK \\
\hline USA & Metropolis / Converdyn & In operation & 15000 t HM/year & CONVERDYN & CONVERDYN \\
\hline
\end{tabular}

\subsubsection{Enrichment}

The enrichment market has seen several significant changes in the last decade. First, the technology revolution moving from gaseous diffusion to centrifuge enrichment has finally completed with the retirement of the large Georges Besse and Paducah facilities (combined capacity of 22 million SWUs/yr) ${ }^{\mathrm{dd}}$. These capacity losses were anticipated and the capacity has been mostly replaced by new centrifuge facilities. Second, the shutdown of reactors in Japan after Fukushima and the slow restart of those reactors have reduced demand and depressed SWU prices. Spot prices have fallen steadily from $\$ 160 /$ SWU in 2009-2010 to below $\$ 60 /$ SWU today. Prices are likely to recover some as more plants in Japan are restarted and more plants under construction are completed, but it is unlikely prices will climb back to former levels. This is because the clearing price of SWUs is set by the highest cost producer, and with the retirement of the gaseous diffusion plants, that highest production cost has significantly dropped. This also impacts profit margin for all producers, which will make it harder for new entrants to the market. Because growth is occurring primarily in Asia, there will likely be some continued expansion of plants in that region. Over the longer term, the enrichment market may see a second technology revolution from centrifuge enrichment to laser enrichment, which promises to be even more efficient but has not yet been deployed commercially.

Table 10 lists the main facilities for enrichment of uranium. The design capacity of these facilities was initially obtained from the IAEA Nuclear Fuel Cycle Information System (INFCIS), but this information was found to be dated and was updated to reflect the recent capacity additions at newer or upgraded facilities in China, Russia and the U.S. A recent Harvard report on enrichment in China [67] estimates capacity as of the end of 2015 at Lanzhou of 2.7 million SWU/yr, at Hanzhong (Shaanxi) of 2.2 million SWU/yr, and possibly an additional 0.8 million SWU/yr at a third site (Emeishan), with additional construction in progress. The WNA website listed higher capacities at the individual Russian enrichment facilities than IAEA, but the total of the individual facility capacities (23.7 million SWU/yr) is less than WNA's 2013 total for Russia of 26 million SWU/yr. The URENCO USA website indicates capacity at its Eunice, NM plant to be 4.6 million SWU/yr as of December, 2015, with an eventual planned capacity of 5.7 million SWU/yr. Total listed capacity is 56,000 MTSWU/yr, which is slightly less than WNA's

dd SWU = Separative Work Units. For more information, see http://www.urenco.com/about-us/business-activity/nuclear-fuelsupply-chain/separative-work-unit 
projected global capacity by 2015 of $~ 58.6$ million SWUs but well above WNA’s 2015 estimated annual enrichment needs of $\sim 47.3$ million SWUs [68].

One way to expand capacity is to add additional cascades to existing facilities or to upgrade the centrifuges of existing cascades, so facility capacities of facilities may increase incrementally over time. Facilities can also incrementally decrease capacity when markets are soft by not replacing failed centrifuges. LEU is also available from secondary sources, including stored stocks, re-enrichment of depleted uranium using otherwise unneeded SWUs ${ }^{\mathrm{ee}}$ and for a time, from down-blended excess highly enriched uranium (HEU) ${ }^{\mathrm{ff}}$ from the Russian military program.

Rosatom claims to have 45\% of the world's enrichment market. Exports are via their TENEX subsidiary, which claims to have customers in 16 countries [69]. These include some large customers such as Japan [70] and the U.S. [71]. The 1993 agreement for shipment of down blended uranium from Russia to the U.S. that supplied roughly half of all U.S. commercial needs ended in 2013 [72].

URENCO has facilities in Germany, the Netherlands, the UK and the U.S. and claims contracts with "more than 50 utilities in 19 countries." [73].

AREVA NC is the other main supplier of enrichment services for export, operating Georges Besse II, a centrifuge facility that replaced the original Georges Besse gaseous diffusion facility in 2011.

The remaining facilities listed primarily support domestic needs, though China may be in a position to export. Because enrichment is fungible any needs supplied domestically modify international demand. Also, technical aspects of centrifuge technology require keeping plants running even when demand is low, so excess capacity is typically used to re-enrich depleted uranium or build up LEU stocks or produce uranium at natural enrichment levels to compete with primary uranium production.

Currently the U.S. is a net importer of enriched uranium. For this to change, one or more of the proposed enrichment facilities would need to be constructed, which is considered to be unlikely. Constructions of new enrichment facilities in the U.S. have been placed on hold (AREVA's Eagle Rock facility in Idaho) or cancelled (Centrus’ American Centrifuge Project in Ohio).

While PHWRs do not require uranium enrichment, they do require a supply of heavy water, with is water enriched in deuterium (the Hydrogen isotope ${ }^{2} \mathrm{H}$ ). There are multiple processes for producing heavy water, including distillation, electrolysis and several chemical processes [74]. These processes are energy intensive, making heavy water expensive to produce. Heavy water is a significant cost component for new CANDU reactors. Current production for export is primarily in Argentina and India.

ee Centrifuges have fewer maintenance problems if they are kept running, so enrichment facilities that do not have enough orders to use all of their capacity may use the extra capacity to extract additional ${ }^{235} \mathrm{U}$ from stocks of depleted uranium at the facility.

${ }^{\mathrm{ff}} \mathrm{HEU}$ is uranum enriched to $20 \%$ or more in ${ }^{235} \mathrm{U}$. Russia mixed excess HEU with natural uranium $\left(\sim 0.71 \%{ }^{235} \mathrm{U}\right)$ or depleted uranium (typically $\sim 0.25 \%{ }^{235} \mathrm{U}$ ) to provide LEU at desired enrichments for LWR fuel $\left(\sim 3-5 \%{ }^{235} \mathrm{U}\right)$. 
Table 10 - Information on current major global enrichment facilities (IAEA)

\begin{tabular}{|c|c|c|c|c|}
\hline $\begin{array}{l}\text { Host } \\
\text { Country }\end{array}$ & Facility Name & $\begin{array}{l}\text { Design } \\
\text { Capacity } \\
\text { (million } \\
\text { SWU/yr) }\end{array}$ & Owner & Operator \\
\hline China & Lanzhou 2 & 2.7 & CNNC - China & Unknown \\
\hline China & $\begin{array}{l}\text { Shaanxi Uranium } \\
\text { Enrichment Plant }\end{array}$ & 2.2 & CNNC - China & $\begin{array}{l}\text { Shaanxi Uranium } \\
\text { Enrichment Plant }\end{array}$ \\
\hline China & $\begin{array}{l}\text { Emeishan Uranium } \\
\text { Enrichment Plant }\end{array}$ & 0.8 & CNNC - China & Unknown \\
\hline France & Georges Besse II & 7.5 & AREVA NC & AREVA NC \\
\hline Germany & $\underline{\text { Urenco Germany GmbH }}$ & 4.5 & $\begin{array}{l}\text { URENCO } \\
\text { Enrichment Co. Ltd }\end{array}$ & $\begin{array}{l}\text { URENCO Germany } \\
\text { GmbH }\end{array}$ \\
\hline Japan & $\begin{array}{l}\text { Rokkasho Uranium } \\
\text { Enrichment Plant }\end{array}$ & 1.05 & JNFL - Japan & JNFL - Japan \\
\hline Netherlands & Urenco Nederland & 4.5 & $\begin{array}{l}\text { URENCO } \\
\text { Enrichment Co. Ltd }\end{array}$ & URENCO Nederland BV \\
\hline Russia & Angarsk & $\underline{2.6}$ & TVEL - Russia & JSC AECC - Russia \\
\hline Russia & $\begin{array}{l}\text { Ekaterinburg (Sverdlovsk- } \\
\underline{44)}\end{array}$ & $\underline{10.0}$ & TVEL - Russia & JSC UECC - Russia \\
\hline Russia & Krasnoyarsk & 8.7 & TVEL - Russia & JSC PA ECP - Russia \\
\hline Russia & $\begin{array}{l}\text { Siberian Chemical } \\
\text { Combine (Seversk) } \\
\end{array}$ & $\underline{3.0}$ & TVEL - Russia & JSC SCC - Russia \\
\hline UK & Urenco UK Ltd & 4.0 & URENCO & URENCO \\
\hline USA & Urenco USA & 4.6 & URENCO & URENCO \\
\hline
\end{tabular}

\subsubsection{Fuel fabrication}

Fuel fabrication involves multiple steps and includes conversion of $\mathrm{UF}_{6}$ (LWRs and GCRs) or $\mathrm{U}_{3} \mathrm{O}_{8}$ (HWRs) into $\mathrm{UO}_{2}$, fabrication (pressing and sintering) of pellets/pins, fabrication of zirconium cladding tubes, inserting the fuel in the tubes and building fuel assemblies. Several of these steps may take place in the same facility or in different facilities in a supply chain. Appendix B-4 provides information on the facilities performing each of these functions, along with their capacity, owner and operator. The total capacity is roughly 18,000 tonnes/year, compared to an estimated need of 10,000-11,000 tonnes/year ( $1 / 3^{\text {rd }}$ HWR and $2 / 3^{\text {rd }}$ LWR $)$.

While this activity was not able to systematically identify supplier/customer relationships, a number of relationships were noted. The best assumption for the remaining relationships is that fuel is obtained from the reactor vendor. The specific arrangements for fuel fabrication identified include:

- AREVA claims to supply 35\% of the market for light water reactor assemblies and to be supplying fuel assemblies for 125 of the world's 288 operating PWRs and BWRs (excluding VVERs).

O AREVA will supply fuel for 25 years for the new reactors they seek to construct in India

- Russia's Rosatom TVEL claims to have $17 \%$ of the fuel fabrication market [75]. TVEL supplies fuel to power reactors in Russia, Armenia, Bulgaria, China, Czech Republic, Finland, Hungary, India, Iran, Slovakia, Sweden, and Ukraine, and jointly with AREVA to Germany, Netherlands, Switzerland, and UK.

o Russia's TVEL agreed in 2009 to continue to supplying assemblies to Ukraine in the short term and to assist in a domestic fabrication facility in Ukraine in the longer term [76] 
o Russia will supply fuel for the reactors it will construct in Bangladesh and Turkey

- Westinghouse claims to manufacture more types of nuclear fuel than any other supplier, including being a single-source provider for PWRs, BWRs, AGRs, and VVERs. A listing of customers was not available.

o Westinghouse is supplying assemblies to Ukraine using the fabrication facility in Sweden [77]

o Westinghouse has agreed to help CNNC produce fuel for the AP1000 plants being built in China [78]

o Westinghouse supplies fuel to South Africa [79]

o Westinghouse supplies fuel to EDF for use in French reactors, using facilities in Sweden, the UK, and Spain [80]

o Westinghouse is a second supplier of VVER fuel outside Russia [81].

- Cameco is the leading manufacturer of fuel assemblies for CANDU reactors worldwide.

- GE-Hitachi is a major provider of fuel for boiling water reactors and also manufactures CANDU fuel.

Note that there is some overlap apparent from the above claimed markets, indicating some competition.

\subsubsection{Spent fuel wet and dry storage}

The scope of this study included investigation of trends in spent fuel storage. A total of 30 wet and 100 dry storage facilities were identified, but this is probably an incomplete list, as wet storage is typically considered part of a reactor plant. Almost all storage was on a reactor site, including a large number of the dry storage sites identified in the U.S. While some shipment of spent fuel has occurred between countries, primarily for reprocessing but also for storage in Russia, no major trends were noted.

\subsubsection{Reprocessing}

Table 11 is a list of operating reprocessing facilities. Reprocessing in the current LWR-only systems is not particularly economical from a net-present value analysis perspective. While the recovered plutonium does offset LEU in fuel, reducing uranium and enrichment requirements by $\sim 15 \%$, reprocessing and mixed U/Pu fuel fabrication are expensive operations. However, the infrastructure and experience are necessary to enable transition to a closed fuel cycle using FBRs that could eventually eliminate the need for enrichment and reduce uranium needs by up to $99 \%$. This would make nuclear energy highly sustainable from a natural resource perspective. For this reason, countries with reprocessing facilities are also usually researching FBRs.

Only a limited number of countries have their fuel reprocessed to make MOX fuel, so while the capacities are small compared to the amount of fuel discharged annually, the utilization is below the listed capacity.

Historically the reprocessing market was limited to only three suppliers in France, Russia, and the UK, and they all primarily reprocessed domestically irradiated fuels with excess capacity available for foreign customers.

- The UK is phasing out of the business and has only been working off existing contracts pending closure of the Thermal Oxide Reprocessing (Thorp) facility in 2018 [82].

- The La Hague facility in France has sufficient capacity to reprocess all domestic fuel as well as some foreign fuel and has provided reprocessing services to several countries in the past. The primary foreign customers for La Hague have been Germany and Japan, but with the German 
phase-out of nuclear energy and Japan constructing their own reprocessing facility, the market is becoming more limited. The French model is to return reprocessing wastes to the generating country.

- The Russian Mayak facility reprocesses fuel for the Russian Federation and currently for 6 reactors in Ukraine ( $107 \mathrm{tHM} / \mathrm{yr})^{\mathrm{gs}}$ [83]. While designed for a capacity of $400 \mathrm{tHM} / \mathrm{yr}$, the RT1 chemical reprocessing line at Mayak apparently has been running at a reduced level and is planned to be updated in the next few years [84]. Russia has plans to expand reprocessing capacity, with a 250 tHM/yr Trial and Demonstration Centre under construction and a new 800 tHM/yr RT-2 line originally planned for completion in 2025 but now postponed. The Russian model has been to keep reprocessing products and wastes in Russia.

- Japan's facility is in commissioning and not yet operational, but is still viewed as essential for nuclear energy to play a long-term role in Japan's quest for energy independence.

- India also has limited reprocessing for HWR fuel (not listed), which is typically not reprocessed due to the low plutonium content. India also has a long-term role for nuclear energy in their energy independence plans, with the next step involving U/Pu fueled FBRs, followed eventually by thorium based breeder reactors to utilize their large thorium reserves.

- China and South Korea are also considering reprocessing.

Table 11 - Information on current global reprocessing facilities

\begin{tabular}{|l|l|l|l|l|}
\hline $\begin{array}{c}\text { Host } \\
\text { Country }\end{array}$ & \multicolumn{1}{|c|}{ Facility Name } & Design Capacity & Owner & Operator \\
\hline France & $\underline{\text { UREVA NC La Hague - }}$ & $1000 \mathrm{t} \mathrm{HM} /$ year & COGEMA - France & AREVA NC \\
\hline France & $\begin{array}{l}\text { AREVA NC La Hague - } \\
\text { UP3 }\end{array}$ & $1000 \mathrm{t} \mathrm{HM} /$ year & COGEMA - France & AREVA NC \\
\hline Japan & $\underline{\text { Rokkasho }}$ & $800 \mathrm{t} \mathrm{HM} /$ year & JNFL - Japan & JNFL - Japan \\
\hline Russia & $\underline{\text { RT-1, Combined Mayak }}$ & $400 \mathrm{t} \mathrm{HM/year}$ & TVEL - Russia & Mayak Production Association (PDF) \\
\hline UK & $\begin{array}{l}\text { NDA Magnox } \\
\text { Reprocessing }\end{array}$ & $1500 \mathrm{t} \mathrm{HM} /$ year & $\underline{\text { NDA - UK }}$ & Sellafield Ltd. (SLC) \\
\hline UK & $\underline{\text { NDA Thorp }}$ & $900 \mathrm{t} \mathrm{HM} /$ year & $\underline{\text { NDA - UK }}$ & $\underline{\text { Sellafield Ltd. (SLC) }}$ \\
\hline
\end{tabular}

\subsection{Supplier Trends}

One trend that has been ongoing for many years is for new nuclear programs of all sizes to initially buy from a vendor, then partner and increase domestic content, then begin to develop facilities for additional parts of the fuel cycle. The main driver is local jobs and local control, often explained in terms of energy security. They will also develop domestic training and research facilities.

gg Nuclear fuel reprocessing capacity is usually stated in units of tonnes heavy metal per year or tonnes initial heavy metal per year, where heavy metal refers to the thorium, uranium, plutonium and heavier actinide metals in the fuel. "Initial” refers to the heavy metal in fresh fuel, some of which is converted to fission products during irradiation. 
This trend is likely to continue. Representatives to a recent IAEA meeting were asked in a survey [85] to indicate their country's current and future indigenous desires for "mastering” mining/milling, conversion, and fuel fabrication. Within existing programs, 60-70 \% indicated current mastery and anticipated mostly staying at those levels, while newcomers wished to achieve $~ 50 \%$ mastery in the medium term and $70-80 \%$ in the long term.

Reactor vendors still appear to have the upper hand when it comes to fuel supply, even though customers generally would like to have more than one provider. In the IAEA meeting survey, users of fuel cycle services indicated a preference for multiple vendors - at least 2 and preferably 3 or more -to guarantee security of supply, but vendors are typically reluctant to license their fuel designs to others.

If a country is comfortable with the security of supply and has a smaller program, they may forego development of fuel cycle infrastructure. With supply assurances, some newcomer countries are declaring they will not develop fuel cycle facilities (other than storage), and in particular will waive their rights to develop enrichment. This provides non-proliferation assurances while also recognizing the cost of independent development and the economies of scale of supporting fuel cycle facilities. Two fuel banks have been established in Russia and Kazakhstan to improve assurance of fuel supply.

\subsection{Developing Relationships}

Russia's Rosatom TVEL is actively pursuing licensing of fuel designs and component production to expand the range of reactors they can support. For example, they recently became a qualified supplier of pressure tubes for CANDU reactors, a key step in becoming a CANDU fuel provider [18].

Some current Rosatom TVEL customers are considering alternate sources for fuel for VVER reactors. TVEL is reluctant to license their fuel design and lose their current monopoly, so other fuel vendors have instead had to develop and test their own independent fuel designs. Ukraine has been actively testing Toshiba-Westinghouse fuel fabricated in Sweden based on a June 2000 U.S. agreement to help Ukraine reduce their dependence on Russia [86]. The lengthy process of proving the fuel via lead test assemblies and partial cores started in 2003 and is finally winding down, with Ukraine expected to soon expand the use of Westinghouse fuel to additional Russian-designed reactors [87]. Finland operated a similar qualification program with Westinghouse fuel fabricated in the UK used in batch quantities from 20012007.

The European Union rules require all power plants to have more than one fuel supplier in the long term $[88,89]$, and has funded a program to establish security of supply (e.g. a second supplier) for Russiandesigned reactors in the EU [90], which includes Bulgaria, Czech Republic, Finland, Hungary, and Slovakia. Members of the Slovak Parliament have also expressed interest in diversifying their fuel supply away from Rosatom, but again significant testing will be required [91].

Rosatom is offering a "build, own, operate" (BOO) arrangement for new reactor construction which includes supply of fuel and takeback of spent fuel. The four VVER-1200 reactors to be constructed in Turkey are the first to be contracted under this approach. 


\section{SPECIAL TOPICS}

\subsection{Advanced Reactors - Generation IV potential}

The development of advanced Generation IV (Gen IV) reactors is still ongoing with no commercial products. Gen IV includes a number of reactor designs offering some combination of higher outlet temperatures and fast neutrons. The higher outlet temperatures increase thermal efficiency and enable more process heat applications such as synthetic fuels. The fast neutrons enable closed fuel cycles with significantly higher resource utilization.

The main classes of Gen IV reactors are Very High Temperature Reactors, Supercritical Water-Cooled Reactors, Molten Salt Reactors, Sodium Fast Reactors, Lead Fast Reactors, and Gas Fast Reactors.

The most progress is occurring with the sodium-cooled FBRs.

- Russia has been developing the technology in steps for decades with a series of these reactors including BOR-60, BN-350, BN-600 and the recently completed BN-800 (880 MWe) which was connected to the grid on December 11, 2015. The final planned reactor in the series which would be the commercial design is the $\mathrm{BN}-1200$ which is indefinitely postponed past 2030 while the $\mathrm{BN}-800$ is used to improve the fuel design. The BN-800 is the first in the series to use uranium/plutonium oxide fuel, which is a requirement for closing the fuel cycle.

- India built a small test reactor in 1985, then jumped to the prototype FBR (500 MWe), which is expected to go critical some time in 2016, operating on uranium/plutonium oxide fuel. After a year of successful operation, plans are to then begin construction of two reactors of the final commercial design of 600 MWe.

- China has a 20 MWe experimental fast reactor that achieved first criticality in 2010. There have been separate paths forward -

o Construction of the Chinese Demonstration Fast Reactor (1000 MWe) beginning in 2017, followed by a 1200 MWe commercial design in 2028. This has apparently been scaled down to the CFR600 and CFR100, following the same schedule.

o Construction of two BN-800 reactors (originally to start in 2013), per an agreement signed with Russia in 2009. [92]

o Construction of a prototype 600 MWe traveling wave reactor with TerraPower (U.S. company) is scheduled to begin in 2018 per an agreement signed in September 2015. [93]

- France has also been developing fast reactor technology for decades and operated prototype (Phenix) and demonstration (Super Phenix) facilities that were shut down in 2010 and 1998 respectively. France is now designing the ASTRID demonstration plant, with a construction decision scheduled by 2019. They are also identifying the fuel cycle facilities required to provide U-Pu MOX fuel for the reactor.

- The U.S. government operated experimental fast reactors from 1951 (EBR-1) to 1994. Several private efforts to design fast reactors are in progress, with TerraPower's scheduled project in China the most advanced.

- Japan’s prototype fast reactor (Monju, $246 \mathrm{MWe}$ ) is still shut down after a 2010 fuel handling accident until a government committee decides on a new operator for the reactor's management and oversight [12].

The Very High Temperature Reactor (VHTR) effort has made some progress in China. China completed a demonstration pebble-bed high temperature reactor, HTR-10, in 2003 and now has a 210 MWe 
demonstration project under construction, HTR-PM. Several other countries have developed designs but none have proceeded to construction.

A large number of molten salt reactors have been proposed, particularly as the basis of small modular reactors. None are under construction.

The remaining Gen IV concepts remain in the R\&D stage. According to the 2013 update of the Gen IV roadmap [94], Russia is carrying out design activities for both a lead-cooled (BREST-300) and a leadbismuth eutectic cooled (SVBR-100) fast reactor, with both expected to be in operation sometime after 2020. A decision on a supercritical water cooled reactor prototype is scheduled for 2017. The primary design approaches are a pressure vessel concept, currently led by a EURATOM partnership and a pressure tube concept proposed by Canada. The design for a small experimental gas-cooled fast reactor is expected to be developed in the next 10-20 years. More information on Gen IV status is available in a 2014 special edition of Progress in Nuclear Energy [95].

\subsection{Near-Term Reactors - SMR potential}

The acronym SMR can stand for small modular reactor or small and medium reactor, which can be a source of confusion. The usage seems to be evolving to standardize on the modular definition, and that is what is used here. The World Nuclear Association defines SMRs as follows:

"Small modular reactors (SMRs) are defined as nuclear reactors generally 300MWe equivalent or less, designed with modular technology using module factory fabrication, pursuing economies of series production and short construction times. This definition, from the World Nuclear Association, is closely based on those from the IAEA and the U.S. Nuclear Energy Institute.” [96]

A number of different SMR designs have been proposed and some are progressing:

- China - The 210 MWe HTR under construction and just discussed as a GEN IV concept is considered to be a modular design. China also is planning to construct two units of the $100 \mathrm{MWe}$ ACP100 integral PWR.

- Russia - Construction was started in 2007 and expected to be completed in 2019 on a $70 \mathrm{MWe}$ floating plant composed of two identical 35 MWe reactor units [97]. Russian firms are also developing a 50 MWe reactor for ice breakers, the RITM-200.

- Argentina - Construction was started on a 25 MWe prototype of Argentina's CAREM reactor in 2014. The prototype is to be followed by a larger 100-200 MWe version.

- $\quad$ South Korea - The 90 MWe SMART integral PWR reactor received design certification in 2012. In 2015, an MOU was signed with Saudi Arabia to construct two SMART reactors there [98] but no construction schedule has been announced.

- India - A cooperation agreement was signed with Sri Lanka in 2015 that included the possibility of future sales of small-scale reactors [99]. Sri Lanka expressed interest in establishing $600 \mathrm{MWe}$ of nuclear capacity by 2030. The design was not specified.

- U.S./Japan - GE Hitachi proposed constructing two PRISM (311 MWe) sodium fast reactors in the UK as an option for disposing of the country's 140 tonne plutonium stockpile $[100,101]$.

- A number of designs have been proposed in the U.S., and two designs have received governmental support from a cooperative grant of \$452M for SMR development and licensing support. 
o In 2012, Gen4 Energy ${ }^{\text {hh }}$ (25 MWe fast reactor), Holtec (140 MWe PWR) and NuScale (\$45 MWe PWR) signed agreements with DOE to work with the Savannah River Site and Savannah River National Laboratory to select sites for demonstrations.

o In 2013, BWXT's mPower 180 MWe design was chosen to receive DOE funding in design development and licensing support, but then stopped development in 2014 after expending \$111M.

o Late in 2013, in a second round of vendor design competition, NuScale was selected and is receiving a cooperative grant to support design development and licensing for its 45 MWe design. This effort is active, with the Utah Associated Municipal Power Systems (UAMPS) and Energy Northwest planning for a demonstration at the Idaho National Laboratory. DOE is providing up to $\$ 217 \mathrm{M}$ in matching funds to support a design certification application and licensing support to include the combined construction and operation license. The demonstration is to be operational by 2024 [102].

o The Tennessee Valley Authority (TVA) has filed an Early Site Permit application for SMR Deployment at their Clinch River Site, with DOE providing matching funds.

Many other SMR designs are in earlier stages of development. The IAEA published a SMR booklet [103] describing 31 designs, including 23 water cooled reactors and 9 high temperature gas cooled reactors. Both the IAEA [104] and the World Nuclear Association's web page on small reactors [96] do not provide as much technical detail as the IAEA publication, but have a wider range of concepts, including fast reactors and molten salt reactors.

While niche applications for SMRs have been proposed, the ultimate intent of proponents is to be able to compete with LWRs and PHWRs and other forms of electricity generation. The concept is that smaller, simpler designs coupled with factory fabrication will result in much faster construction, lower lifecycle costs, and easier financing. SMRs may also be available to a broader market than large reactors due to the smaller amount of capital that must be financed. However, smaller reactor cores are less efficient with more neutron leakage and require higher enrichment to achieve the same fuel burn-up. The number of reactor operators, security personnel and other staffing requirements per MWe of capacity are also higher. These differences are small, but add up, and explain why the trend over the last half century has been to ever larger reactors in multi-unit plants. The as yet unproven design and fabrication efficiencies and lower per-facility financing costs must overcome these negatives.

Many countries with smaller grids have expressed interest in some type of SMRs, but the technology needs to be demonstrated and cost efficiencies proven to be able to overcome the impacts of loss of economies of scale before any significant market is expected to develop.

On March 17, the UK government announced an SMR competition. The objective of the initial phase of the competition is "to gauge market interest among technology developers, utilities, potential investors, and funders in developing, commercializing and financing SMRs in the UK." The government also plans to publish an SMR Delivery Roadmap later this year. [105]

\footnotetext{
hh Hyperion Power Generation Inc. changed their name to Gen4 Energy, Inc. on March 13, 2012.
} 


\section{CONCLUSIONS}

This report has documented the findings of the first phase of the Global Nuclear Markets project, along with a description of the work performed.

Extensive lists of existing and planned fuel cycle facilities and reactors under construction or planned were developed and general relationships between suppliers and customers identified. Specific relationship identification was limited due to a lack of publicly available information. The main sources of facility information were often found to be slightly dated and not always in agreement, especially with respect to the status of planned reactor projects and the capacities of existing conversion and enrichment facilities. Efforts to validate data in these areas revealed the constantly changing nature of the information.

The main conclusions of the work include:

- Financing for a new nuclear reactor projects continue to be a significant obstacle for most countries wanting to include nuclear in their energy mix.

o Countries like China and Russia that have the ability to offer financing terms for reactor construction that are outside of the OECD Financing Nuclear projects guideline can have a competitive advantage.

- Reactor construction performance seems to have a major impact on where growth is occurring and which providers are obtaining new business.

0 Average construction times under 6 years in Korea and China may be contributing to domestic growth while also providing a competitive advantage for exports by reducing perceived project risk.

o Conversely, established vendors that are struggling to complete current projects may be at a disadvantage for future sales, depending on customer perception of the reasons for project delays.

- Geopolitics may influence reactor projects and reactor vendor choices for smaller countries.

o Russia often has the inside track for new projects in countries with strong political ties.

o China's initial exports are to Pakistan, which has strong trading ties with China.

- Some prototype and demonstration SMRs are under construction and many others are in development. While many countries have expressed interest in SMRs, significant commercial orders have not yet materialized.

- Some progress in fielding prototype advanced "Generation IV" reactors was observed, especially for sodium-cooled fast reactors where Russia and India are both currently completing larger plants. A prototype high temperature gas reactor is under construction in China.

- The Fukushima accident continues to have strong repercussions within Japan, with only limited restarts of existing reactors and lower targets for nuclear energy's market share going forward.

o Outside of Japan, the impact of Fukushima on the reactor construction industry has been mixed with countries with struggling programs or overall low energy demand growth apparently impacted more than countries with thriving programs and higher energy demand growth.

o The prolonged shutdown of reactors in Japanese reactors and slower growth globally has had a greater impact on the fuel supply chain.

- Each stage of the fuel cycle front end appears to have ample supply capacity to meet current and near-term demand 
o Spot prices for yellowcake, conversion and enrichment are all down significantly since Fukushima. Some new enrichment facilities have been postponed or cancelled.

o While reactor vendor typically provide fuel for the initial years of operations for new reactors, more fuel supplier diversification and competition is occurring for refueling of reactors when fuel contracts come up for renewal.

o The European Union is requiring new reactors to have more than one fuel supplier in the medium term to improve security of supply.

o Westinghouse is emerging as a second supplier of VVER fuels outside Russia. 


\section{REFERENCES}

1. Outline History of Nuclear Energy, World Nuclear Association. http://www.worldnuclear.org/information-library/current-and-future-generation/outline-history-of-nuclearenergy.aspx

2. A Technology Roadmap for Generation IV Nuclear Energy Systems, Generation IV International Forum, GIF-002-00, December 2002.

3. Nuclear Fuel Fabrication, World Nuclear Associate, http://www.world-nuclear.org/informationlibrary/nuclear-fuel-cycle/conversion-enrichment-and-fabrication/fuel-fabrication.aspx

4. Power Reactor Information System, International Atomic Energy Agency, https://www.iaea.org/PRIS/home.aspx

5. Country Nuclear Power Profiles 2015 Edition, International Atomic Energy Agency, http://wwwpub.iaea.org/MTCD/Publications/PDF/CNPP2015_CD/pages/index.htm

6. Country Profiles, World Nuclear Association, http://www.world-nuclear.org/informationlibrary/country-profiles.aspx

7. NEI SmartBrief, http://www2.smartbrief.com/news/nei/archive.jsp

8. Hualong One joint venture officially launched, World Nuclear News, March 17, 2016. http://www.world-nuclear-news.org/C-Hualong-One-joint-venture-officially-launched1703164.html

9. 2016 Top Markets Report - Civil Nuclear, International Trade Administration, U.S. Department of Commerce, May 2016.

10. Market Competition in the Nuclear Industry, Nuclear Energy Agency, Organisation for Economic Co-operation and Development, 2008. https://www.oecd-nea.org/ndd/pubs/2008/6246-marketcompetition.pdf

11. Ontario unveils \$12.8B Darlington nuclear refurbishment, CBC News, January 11, 2016. http://www.cbc.ca/news/canada/toronto/darlington-nuclear-refurbishment-1.3395696

12. Fate of troubled Monju reactor hangs in the balance, The Japan Times, November 23, 2015. http://www.japantimes.co.jp/news/2015/11/23/reference/fate-of-troubled-monju-reactor-hangs-inthe-balance/

13. Advances in Small Modular Reactor Technology Developments, International Atomic Energy Agency, 2014.

14. http://www.world-nuclear.org/information-library/nuclear-fuel-cycle/mining-of-uranium/worlduranium-mining-production.aspx

15. Conversion and Deconversion, World Nuclear Association, http://www.worldnuclear.org/information-library/nuclear-fuel-cycle/conversion-enrichment-and-

fabrication/conversion-and-deconversion.aspx

16. Uranium Enrichment, World Nuclear Association, http://www.world-nuclear.org/informationlibrary/nuclear-fuel-cycle/conversion-enrichment-and-fabrication/uranium-enrichment.aspx

17. The UX Consulting Company, LLC, http://www.uxc.com/review/UxCPriceChart.aspx?chart=spot-swu-full

18. Summary of Rosatom's TVEL Fuel Company economic activities in 2013, Rosatom News. http://www.rosatom.ru/en/presscentre/news/cea55d00423e854e9681d7b32a194887 
19. Returning spent nuclear fuel to Russia from Iran envisaged in agreements - Rosatom, TASS Russian News Agency, April 3, 2015. http://tass.ru/en/world/787141

20. Finland approves underground nuclear waste storage plan, Reuters, November 12, 2015. http://www.reuters.com/article/us-finland-nuclear-idUSKCN0T121120151112

21. Rosatom offers emerging nations nuclear package - paper, Reuters, May 13, 2013. http://uk.reuters.com/article/uk-rosatom-nuclear-russia-idUKBRE94C09G20130513

22. Treaty on the Non-Proliferation of Nuclear Weapons (NPT), United National Office for Disarmament Affairs. http://www.un.org/disarmament/WMD/Nuclear/NPT.shtml

23. Nuclear Suppliers Group. http://www.nuclearsuppliersgroup.org/en/

24. Consolidated Version of the Treaty Establishing the European Atomic Energy Community, EURLex Access to European Union law. http://eur-lex.europa.eu/legalcontent/EN/TXT/?uri=CELEX:12012A/TXT

25. 123 Agreements for Peaceful Cooperation, National Nuclear Security Administration. http://nnsa.energy.gov/aboutus/ourprograms/nonproliferation/treatiesagreements/123agreementsf orpeacefulcooperation

26. After a pause of four decades, India to receive nuclear fuel supply for Canada in autumn 2015, The Economic Times, The Times of India, June 15, 2015. http://economictimes.indiatimes.com/news/politics-and-nation/after-a-pause-of-four-decadesindia-to-receive-nuclear-fuel-supply-from-canada-in-autumn-2015/articleshow/47669676.cms

27. UAE awards nuclear fuel contracts, World Nuclear News, August 15, 2012. http://www.worldnuclear-news.org/ENF-UAE_awards_nuclear_fuel_contracts-1508124.html

28. International Status and Prospects for Nuclear Power 2014, Board of Governors General Conference, International Atomic Energy Agency, GOV/INF/2014/13-GC(38)/INF/6, August 4, 2014.

29. Emerging Nuclear Energy Countries, World Nuclear Organization, http://www.worldnuclear.org/information-library/country-profiles/others/emerging-nuclear-energy-countries.aspx

30. MHI Export Experiences, https://www.mhi-global.com/ee/nuclear/global/record.html

31. Turkey ratifies agreement for new plant at Sinop, World Nuclear News, April 2, 2015. http://www.world-nuclear-news.org/NN-Turkey-ratifies-agreement-for-new-plant-at-Sinop02041502.html

32. Cooperation Agreement between SNPTC and NECSA Signed under the Witness of Zi Jinping and Jacob Zuma, SPIC Photo News, December 4, 2015. http://eng.spic.com.cn/NewsCenter/PhotoNews/201512/t20151209_257136.htm

33. Nuclear Construction $1^{\text {st }}$ Nuclear Power Plant in Turkey, Linkedin Pulse, May 4, 2015. https://www.linkedin.com/pulse/nuclear-construction-1st-power-plant-turkey-stefania-jourdancara

34. Changjiang-2 on China's Hainan Island Connected to the Grid, World Nuclear Industry Status Report, June 21, 2016. http://www.worldnuclearreport.org/Changjiang-2-on-China-s-HainanIsland-Connected-to-the-Grid.html

35. Nuclear Power in India, World Nuclear Association, updated February 26, 2016. http://www.world-nuclear.org/information-library/country-profiles/countries-g-n/india.aspx

36. India ratifies nuclear liability convention, hopes to win foreign investment, Reuters, Feb. 4, 2016. http://www.reuters.com/article/india-nuclear-idUSKCNOVD2J1 
37. New power supply plan, The Korea Times, June 9, 2016. http://www.koreatimes.co.kr/www/news/opinon/2015/06/202_180532.html

38. Hualong One selected for Argentina, World Nuclear News, February 5, 2015. http://www.worldnuclear-news.org/NN-Hualong-One-selected-for-Argentina-0502154.html

39. New direction for UK energy policy, Press release from the Department of Energy \& Climate Change, November 18, 2015. https://www.gov.uk/government/news/new-direction-for-ukenergy-policy

40. Nuclear Energy is Valuable, U.S. News \& World Report, June 8, 2016. http://www.usnews.com/opinion/articles/2016-06-08/stop-prioritizing-solar-and-wind-energyover-nuclear-power

41. (Nuclear) Power to the People, BloombergView, June 9, 2016. http://www.bloomberg.com/view/articles/2016-06-09/-nuclear-power-to-the-people

42. Exelon Will Seek License to Run Nuclear Plant for 80 Years, Bloomberg, June 6, 2016. http://www.bloomberg.com/news/articles/2016-06-06/exelon-said-to-seek-license-to-run-nuclearplant-for-80-years

43. Ontario to squeeze more life out of Pickering nuclear station, CityNews, The Canadian Press, January 11, 2016. http://www.citynews.ca/2016/01/11/ontario-to-squeeze-more-life-out-ofpickering-nuclear-station/

44. New French energy policy to limit nuclear, World Nuclear News, June 18, 2014. http://www.world-nuclear-news.org/np-new-french-energy-policy-to-limit-nuclear-1806144.html

45. Japan Utilities Seen Pushing for Atomic Restarts as Reform Looms, Bloomberg Business, February 14, 2016. http://www.bloomberg.com/news/articles/2016-02-15/japan-utilities-seenpushing-for-atomic-restarts-as-reform-looms

46. Japan restarts first nuclear reactor under new safety rules, Today in Energy, U.S. Energy Information Administration, Aug. 12, 2015. http://www.eia.gov/todayinenergy/detail.cfm?id=22472

47. Court issues surprise injunction to halt Takahama nuclear reactors, The Japanese Times, March 9, 2016. http://www.japantimes.co.jp/news/2016/03/09/national/court-issues-surprise-injunctionhalt-takahama-nuclear-reactors/

48. IEA urges Belgium to take a long-term approach to energy policy, International Energy Agency, May 19, 2016. https://www.iea.org/newsroomandevents/pressreleases/2016/may/iea-urgesbelgium-to-take-a-long-term-approach-to-energy-policy-.html

49. In turnaround, Sweden agrees to continue nuclear power, Agence France-Presse, June 10, 2016. http://www.globalpost.com/article/6775437/2016/06/10/turnaround-sweden-agrees-continuenuclear-power

50. NPPs under construction in foreign counties, Rosatom, accessed March 19, 2016. http://www.rosatom.ru/en/areas_of_activity/npp_design_engineering_construction/npps_under_c onstruction_in_foreign_countries/, Projects, Rosatom, accessed June 23, 2016. http://www.rosatom.ru/en/investors/projects/

51. The Arrangement on Export Credits, Organisation for Economic Co-operation and Development. http://www.oecd.org/trade/xcred/arrangement.htm

52. Financial solution (within Rosatom's integrated offer), Rosatom web site. http://www.rosatom.ru/en/areas_of_activity/additional_service_offerings/financial_solution/ 
53. "Survival of the fittest? World's major nuclear builders are in for a long stretch in the red”, The Bellona Foundation. http://bellona.org/news/nuclear-issues/2015-05-survival-fittest-worldsmajor-nuclear-builders-long-stretch-red

54. EDF, AREVA agree reactor business worth around 2.5 B euro: sources. Reuters, Jan 13, 2016. http://www.reuters.com/article/us-areva-edf-idUSKCN0UR2RF20160113

55. EDF signs preliminary deal to build six nuclear plants in India, Reuters, Jan. 26, 2016. http://in.reuters.com/article/edf-india-nuclear-idINKCN0V41Q0

56. China’s Coming Mass Layoffs: Past as Prologue? The Diplomat, March 3, 2016. http://thediplomat.com/2016/03/chinas-coming-mass-layoffs-past-as-prologue/

57. Nuclear Power in Czech Republic, Country Profiles, World Nuclear Association, updated January 2016. http://www.world-nuclear.org/information-library/country-profiles/countries-a-f/czechrepublic.aspx

58. Money issues key to new builds in Czech Republic and South Africa, Neutron Bytes, blog posted May 24, 2015. http://neutronbytes.com/2015/05/24/money-issues-key-to-new-builds-in-czechrepublic-and-south-africa/

59. Westinghouse fuel assemblies arrive at Zaporozhe plant, World Nuclear News, Feb. 24, 2016. http://www.world-nuclear-news.org/UF-Westinghouse-fuel-assemblies-arrive-at-Zaporozheplant-24021601.html

60. Expanding Primary Uranium Production: A Medium-Term Assessment, R. Eggert, A. Gilmore, and E. Segal, Division of Economics and Business, Colorado School of Mines, Revision 1, April 1, 2011.

61. Russia-India sign \$700mln in nuclear fuel deals, Reuters, February 12, 2009. http://in.reuters.com/article/idINIndia-37956420090212

62. Kazakhstan and India sign nuclear cooperation accord, World Nuclear News, January 26, 2009. http://www.world-nuclear-news.org/newsarticle.aspx?id=24507

63. India, Kazakhstan to carry forward civil nuclear cooperation beyond 2014, The Economic Times, The Times of India, March 5, 2013. http://articles.economictimes.indiatimes.com/2013-0305/news/37469802_1_kazatomprom-india-and-kazakhstan-kazakh-counterpart

64. Australia and India sign bilateral, World Nuclear News, September 8, 2014. http://www.worldnuclear-news.org/NP-Australia-and-India-sign-bilateral-0809147.html

65. Russia and India ready to trade, World Nuclear News, December 5, 2008. http://www.worldnuclear-news.org/NP Russia and India to trade 0512082.html

66. World Nuclear Power Reactors \& Uranium Requirements, World Nuclear Association. http://www.world-nuclear.org/information-library/facts-and-figures/world-nuclear-powerreactors-and-uranium-requireme.aspx

67. China's uranium Enrichment Capacity - Rapid Expansion to Meet Commercial Needs, H. Zhang, Belfer Center for Science and International Affairs, Harvard University, August 2015.

68. Uranium Enrichment, World Nuclear Association. http://www.world-nuclear.org/informationlibrary/nuclear-fuel-cycle/conversion-enrichment-and-fabrication/uranium-enrichment.aspx

69. Company Profile, TENEX, Rosatom State Corporation Company. http://www.rosatom.ru/wps/wcm/connect/tenex/site_eng/company/

70. Update 2 - Russia, Japan seek to bolster economic ties, Reuters, May 12, 2009. http://uk.reuters.com/article/russia-japan-idUKT15134120090512 
71. Russia, U.S. ink uranium enrichment pact for 2013-2022, Sputnik International, December 21, 2012. http://sputniknews.com/russia/20111221/170411168.html

72. Uranium shipment signals end of U.S. - Russian nuclear deal, Reuters, November 14, 2013. http://uk.reuters.com/article/uk-russia-usa-nuclear-idUKBRE9AD14Q20131114

73. URENCO’s Customers, URENCO. http://www.urenco.com/about-us/business-activity/urencoscustomers/

74. Heavy Water: A Manufacturers' Guide for the Hydrogen Century, A.I. Miller, Atomic Energy of Canada, Canadian Nuclear Society Bulletin, vol. 22, no. 1, February, 2001. https://cnssnc.ca/media/Bulletin/A Miller Heavy Water.pdf

75. “The TVEL Fuel Company of Rosatom Creating Future Today”, TVEL nuclear fuel brochure. http://www.tvel.ru/wps/wcm/connect/tvel/tvelsite.eng/resources/b0138d8040dca2c18c70fe60489 32ed2/2_Brochure_nuclear_ENG.pdf?MOD=AJPERES\&CONVERT_TO=url\&CACHEID=b013 8d8040dca2c18c70fe6048932ed2

76. Russia-Ukraine talks on nuclear fuel supplies near completion, Sputnik International, January 22, 2009. http://sputniknews.com/business/20090122/119755215.html

77. More Westinghouse fuel for Ukraine, World Nuclear News, April 11, 2014. http://world-nuclearnews.org/ENF-More-Westinghouse-fuel-for-Ukraine-1104144.html

78. Westinghouse signs deals for China nuclear plants, Reuters, January 18, 2011. http://af.reuters.com/article/energyOilNews/idAFWNA906820110118

79. Westinghouse reaches deal in South Africa, Pittsburgh Business Times, March 12, 2013. http://www.bizjournals.com/pittsburgh/blog/morning-edition/2013/03/westinghouse-reachesdeal-in-south.html

80. Westinghouse and EDF sign long-term fuel contract, World Nuclear News, December 18, 2014. http://www.world-nuclear-news.org/ENF-Westinghouse-and-EDF-sign-long-term-fuel-contract18121401.html

81. Diversification of the VVER Fuel Market in Eastern Europe and Ukraine, M. Kirst et al, atw Vol. 60, Issue 3, March 2015. http://www.kernenergie.de/kernenergie-wAssets/docs/fachzeitschriftatw/2015/atw2015_03_kirst_vver_fuel.pdf

82. UK considers options for unreprocessed foreign fuel, World Nuclear News, http://www.worldnuclear-news.org/WR-UK-considers-options-for-unreprocessed-foreign-fuel-0403144.html

83. "New vision on development of nuclear energy generation of Ukraine”, O. Godum, National Nuclear Energy Generating Company ENERGOATOM, presentation at the Dialogue Forum on Roadmaps for a Transition to Globally Sustainable Nuclear Energy System, IAEA, Vienna, Austria, October 2015.

84. Rostechnadzor outlines used fuel targets, World Nuclear News, September 26, 2014, http://www.world-nuclear-news.org/WR-Rostechnadzor-outlines-used-fuel-targets26091401.html

85. Drivers and Impediments for Regional Cooperation on the Way to Sustainable Nuclear Energy Systems, INPRO Dialogue Forum 8, Vienna International Centre, July 30-August 3, 2012.

86. Ukraine Nuclear Fuel Cycle Chronology, Nuclear Threat Initiative, last updated April 2005. http://www.nti.org/media/pdfs/ukraine_nuclear_fuel_cycle.pdf?_=1317248570

87. Westinghouse fuel assemblies arrive at Zaporozhe plant, World Nuclear News, February 24, 2016. http://www.world-nuclear-news.org/UF-Westinghouse-fuel-assemblies-arrive-atZaporozhe-plant-24021601.html 
88. Euratom approves Paks II fuel supply contract, World Nuclear News, April 21, 2015. http://www.world-nuclear-news.org/UF-Euratom-approves-Paks-II-fuel-supply-contract21041501.html

89. The Energy Union on track to deliver, Euratom Supply Agency, Nuclear News Digest, November 2015. http://ec.europa.eu/euratom/observatory news.html

90. Westinghouse-Led Group Wins EU Backing to Diversity Nuclear Fuel Supply to VVER Reactors, Westinghouse Electric Company, June 29, 2015. http://www.westinghousenuclear.com/About/News/View/Westinghouse-led-Group-Wins-EUBacking-to-Diversify-Nuclear-Fuel-Supply-to-VVER-Reactors

91. Slovak regulators skeptical on calls for fuel diversification, Atominfo.ru, January 11, 2015. http://www.atominfo.ru/en/news4/d0335.htm

92. China signs up Russian fast reactors, World Nuclear News, October 15, 2009. http://www.worldnuclear-news.org/NN China signs up Russian fast reactors 1510091.html

93. TerraPower, CNNC team up on travelling wave reactor, World Nuclear News, September 25, 2015. http://www.world-nuclear-news.org/NN-TerraPower-CNNC-team-up-on-travelling-wavereactor-25091501.html

94. Technology Roadmap Update for Generation IV Nuclear Energy Systems, issued by the OECD Nuclear Energy Agency for the Generation IV International Forum, January, 2014. https://www.gen-4.org/gif/upload/docs/application/pdf/2014-03/gif-tru2014.pdf

95. Special Section on Status of Generation IV Reactor Development, Progress in Nuclear Energy, Volume 77, pages 1-420, November 2014. http://www.sciencedirect.com/science/journal/01491970/77

96. Small Nuclear Power Reactors, Information Library, World Nuclear Association. http://www.world-nuclear.org/information-library/nuclear-fuel-cycle/nuclear-powerreactors/small-nuclear-power-reactors.aspx

97. Russian floating nuclear power plant’s port to cost \$78.5 million, Bellona, January 14, 2016. http://bellona.org/news/nuclear-issues/nuclear-russia/2016-01-russian-floating-nuclear-powerplants-port-to-cost-58-million

98. Saudi Arabia teams up with Korea on SMART, World Nuclear News, March 4, 2015. http://www.world-nuclear-news.org/NN-Saudi-Arabia-teams-up-with-Korea-on-SMART0403154.html

99. India seals nuclear energy pact with Sri Lanka, hopes to push back Chinese influence, Reuters, February 16, 2015. http://www.reuters.com/article/us-india-sri-lankaidUSKBN0LK0Y520150216

100. GE Hitachi backs PRISM to solve UK's nuclear waste problem, businessGreen, February 24, 2014. http://www.businessgreen.com/bg/feature/2330280/ge-hitachi-backs-prism-to-solve-uksnuclear-waste-problem

101. PRISM: Technology to Power and Secure our Energy Future, GE-Hitachi. http://gehitachiprism.com/

102. NuScale SMR licensing schedule outlined, World Nuclear News, July 2, 2015. http://www.world-nuclear-news.org/NN-NuScale-SMR-licensing-schedule-outlined0207157.html 
103. Advances in Small Modular Reactor Technology Developments, A Supplement to: IAEA Advanced Reactors Information System (ARES), International Atomic Energy Agency, September 2014.

104. Small and Medium Sized Reactor (SMRs) Development, Assessment and Deployment, International Atomic Energy Agency. https://www.iaea.org/NuclearPower/SMR/

105. UK government launches SMR competition, World Nuclear News, March 18, 2016. http://www.world-nuclear-news.org/NN-UK-government-launches-SMR-competition$\underline{1803165 . h t m l}$

106. Number of nuclear reactors operable and under construction, World Nuclear Association, http://www.world-nuclear.org/nuclear-basics/global-number-of-nuclear-reactors.aspx

107. Lithuania shuts Ignalina plant, World Nuclear News, January 4, 2010. http://www.worldnuclear-news.org/NP-Lithuania_shuts_Ignalina_plant-0401104.html

108. Kudankulam units achieve construction and operation milestones, World Nuclear News, July 16, 2015. http://www.world-nuclear-news.org/RS-Kudankulam-units-achieve-construction-andoperation-milestones-16071501.html 


\section{Appendix A - Additional Information}

\section{A-1. Overview of the Nuclear Fuel Cycle}

The nuclear fuel cycle includes:

- Mining and milling of uranium to produce uranium oxide "yellowcake” $\left(\mathrm{U}_{3} \mathrm{O}_{8}\right)$ for nuclear fuel, with the "natural" uranium having an isotopic content of $\sim 99.29 \%{ }^{238} \mathrm{U}, \sim 0.71 \%{ }^{235} \mathrm{U}^{\mathrm{ii}}$, and a trace of ${ }^{234} \mathrm{U}$.

- Conversion of yellowcake into either uranium hexafluoride $\left(\mathrm{UF}_{6}\right)$ for enrichment or to uranium oxide $\left(\mathrm{UO}_{3}\right)$ for use in unenriched fuel ${ }^{\mathrm{jj}}$

- Enrichment of uranium hexafluoride to increase the amount of the isotope ${ }^{235} \mathrm{U}$, resulting in a "low enriched uranium" (LEU) product with a ${ }^{235} \mathrm{U}$ content of typically 3-5\%, and a "depleted uranium” (DU) byproduct ${ }^{\mathrm{kk}}$ with a ${ }^{235} \mathrm{U}$ content of typically $0.2-0.3 \%$

- Fabrication of nuclear fuel assemblies, including conversion of enriched $\mathrm{UF}_{6}$ (or unenriched $\mathrm{UO}_{3}$ ) to $\mathrm{UO}_{2}$, making fuel pellets, placing the pellets inside cladding tubes to form fuel rods, and arraying the fuel rods along with grid spacers and end caps into a fuel assembly.

- Loading batches of fuel assemblies into nuclear reactors and obtaining a controlled nuclear chain reaction in the reactor core to generate heat used to turn steam or gas turbines linked to electrical generators

- Unloading batches of "spent” used fuel assemblies and placing them in storage

- Either disposing of the used fuel in a geologic repository or "reprocessing” it to recycle usable fuel materials and then disposing of the high level waste generated by reprocessing

\section{A-2. Data Collection Challenges and Gaps}

Much of the effort documented in this report has involved accessing material developed by organizations such as IAEA and WNA with much larger budgets, dedicated staff, and established relationships with information originators.

One issue with the gathered information was inconsistency in how information was reported. The primary sources are aware of this issue, with differences in what is considered to be the start and end of construction, how to report construction projects that are suspended, and even in how to report operating reactors with suspended operations, as described by WNA [106]:

"For example, the Monju reactor in Japan generated electricity for a short time in 1994 and again in 2010. Some organizations consider that Monju entered full operation and is current in a period of long-term shutdown. Others consider that it is still under construction. Also in Japan, although many

\footnotetext{
ii The isotope ${ }^{235} \mathrm{U}$ is the only isotope in nature that is "fissile", meaning that it can maintain a fission chain reaction. A fission chain reaction occurs when a heavy isotope interacts with a neutron and splits into two or more lighter isotopes plus one or more neutrons while also releasing large amounts of energy.

ij Pressurized Heavy Water Reactors, like the CANDU can use unenriched uranium $\left(0.71 \%{ }^{235} \mathrm{U}\right)$ or slightly enriched uranium ( $\sim 0.71$ to $1.0 \%{ }^{235} \mathrm{U}$ ) as fuel. These reactors make up $\sim 6 \%$ of the total deployed global reactor capacity.

kk There are currently only limited uses for DU, so most of it is stored pending potential future uses or disposed as a waste.
} 
reactors were unaffected by the earthquake ... all had to eventually shut down for refueling. . . These reactors are still counted as operable by most sources, although others consider them to be in long-term shutdown.”l

To minimize the impact of the above issues, a single source was typically selected as the starting point for each list of information to ensure some degree of consistency. The IAEA data was generally more recently updated than other sources, so was usually used for this starting point.

The information sources include status information on reactors and fuel cycle facilities, from planned through construction, operating, shut down, decommissioned, etc. Early in the effort, it was noted that some of the forward-looking information on new "planned" facilities, etc. was highly speculative while other information was much more concrete. For example, the PI was aware of some new reactor projects that had been proposed a few years ago, but never moved further than an expression of interest with no specific site or vendor approved. The raw information from the primary sources typically lumped these speculative projects in with other projects which were moving ahead. Recognizing this would impact the quality of analyses, an effort was made to further categorize these reactor projects, as described in Table 12.

Even with the categories in Table 12, considerable judgement was still required for grouping. For example, in the U.S. there are projects that were actively pursued to the point of obtaining early site permits, or even a combined construction and operating license, but are now "banked" on hold, while there are other more recent projects that are actively moving forward but are not yet to the point of applying to the U.S. Nuclear Regulatory Commission (NRC) for construction licenses.

Generally less information was available for non-reactor fuel cycle facilities, so the same system was not used on those lists. However, identified project delays, etc. were documented in notes with hyperlinks to associated news articles.

Table 12 - Categorization of status of new reactor projects

\begin{tabular}{|c|c|}
\hline Term & Definition \\
\hline In Operation & Recently transitioned to commercial operation - \\
\hline Start-up & Construction complete, connected to grid but not yet in commercial operation \\
\hline Under Construction & $\begin{array}{l}\text { Includes time from first nuclear concrete poured through initial criticality, ending at grid connection, and } \\
\text { construction is progressing, }\end{array}$ \\
\hline Construction Stalled & Construction halted before commercial operation \\
\hline Planned & $\begin{array}{l}\text { More progressed than "Planned-A" - Have a site, design, builder, may include initial site preparation - Waiting } \\
\text { on final approval or signed contract. (Also the generic category for projects for which there is insufficient } \\
\text { information to place elsewhere) }\end{array}$ \\
\hline Planned-A & Planned, active, in process of site characterization, selecting design, builder, etc. \\
\hline Planned-C & Cancelled - Project no longer active, never started construction \\
\hline Planned-S & $\begin{array}{l}\text { In standby mode - Includes projects that have achieved some level of development/approval and are } \\
\text { "banked" for future development based on market conditions. }\end{array}$ \\
\hline Planned-P & Postponed - Project is on hold but not considered cancelled, never started construction \\
\hline Proposed & Conceptual, thinking about It, rumored, future plan \\
\hline
\end{tabular}

${ }^{\text {Il }}$ The Nuclear Energy Institute maintains a blog with a running history of reactor news in Japan since Fukushima http://www.nei.org/News-Media/News/Japan-Nuclear-Update 
Naming was another difficulty encountered. This took two forms. First, foreign names for sites and companies sometimes varied in spelling in the literature. An effort was made to confirm site names through map searches when two very similar names were encountered to determine if they were alternate spellings of the same name or actually different places/entities. Second, some site names were discovered to be reused, especially when a previous project at a site failed but a new proposed project was benefiting from the previous site characterization work. These were harder to identify, and required trying to determine if the reactor design or size had changed (likely a new project) or if it was only a change in the company performing construction (likely a restart of a stalled project).

Very little quantitative information was found for fuel services. Typically, news articles only indicated agreements had been reached to provide uranium, fuel fabrication, etc. to a country and possibly a company or a specific reactor plant, without duration or quantity information or specification of the source facilities. This made it very difficult to match suppliers and users for fuel services. An analysis of the total global fuel requirements indicated there is significantly more capacity in currently operating fabrication facilities than needed. Supply and demand for the fuel cycle stages is discussed in more detail in the body of the report.

It was soon determined that the main supplier companies often set up subsidiaries within buyer countries. These subsidiaries may be jointly owned with a domestic partner. The subsidiaries may be formed as soon as a supplier develops an interest in the target country's market (which may not even exist yet). If successful progress is achieved, the original subsidiary may be continued or replaced with a new subsidiary with possibly new or different partners. These arrangements often made it difficult to trace which local company is doing what, so it became much easier to just track the parent company (e.g. AREVA, Rosatom). An effort was made in the project spreadsheet to develop a listing of parent companies and subsidiary owners for all fuel cycle facilities with an emphasis on operating facilities and facilities under construction, but it was not fully populated. It is estimated to be $\sim 70 \%$ complete and more than $90 \%$ complete for the major foreign suppliers. The information includes the parent, owner, operator, and up to three joint venture partners per facility.

The OneNote project file and the project facilities and suppliers spreadsheet are both best described as "in progress” rather than final products. While significant information is included in a searchable and filterable format, the validation continues to be an ongoing effort along with information updating based on new market developments.

\section{A-3. Historic Reactor Market Patterns}

The reactor construction market has been driven by four historic themes. These historic themes are important in understanding current market behaviors and the drivers behind shifts in market leadership.

1. Worsening Construction Performance and Waning Public Support - A number of western countries stopped developing their nuclear power programs in the $\sim 1980-1990$ timeframe due to the interrelated issues of construction delays and cost overruns, declining public support, and safety concerns. While reactor operators also significantly improved operational performance over the same period, this did not seem to impact public opinion.

2. Major Geopolicital Event - The political turmoil and negative economic growth in the breakup of the Soviet Union and its Eastern European dependents placed many nuclear power projects in limbo. Russia has recovered sufficiently to resume domestic projects at a reduced pace. Projects to complete reactors in former Soviet bloc countries have varied based on the availability of financing and changing political alignments and interests. 
3. Consistent/Improving Construction Performance - Larger nuclear power programs in Asia exhibited a pattern of consistent performance, not experiencing the growing construction delays of their western counterparts.

4. Rapid Growth and Diversification - More recently, developing countries with rapid energy demand growth and an associated desire to diversify their energy mix have initiated or are considering nuclear energy programs.

Figure 2 shows the historic reactor construction performance in fourteen countries with significant reactor fleets based on historic reactor construction data. Note that projects finished after 2010 and current projects in progress are not shown, so these graphs do not show current market conditions. They also do not include any impacts of the Fukushima accident.

Belgium, Canada, France, Germany, Spain, Sweden, the UK and the U.S. all fall under the first theme above, exhibited by generally increasing construction time before new projects stopped due to a negative feedback loop where poor construction performance and waning public opinion feed off each other. The timing of the three major reactor accidents has also contributed by giving the feedback loop a push at the worst times. In Italy, campaigning on a referendum to reverse the earlier phase-out of nuclear energy was in progress when Fukushima occurred and the referendum was defeated. In the U.S. and France, public opinion recovered sufficiently after 2000 to support resumption of construction (the nuclear renaissance), but the combination of Fukushima and poor construction performance on the new projects risk restarting their feedback loops too. The UK pattern is somewhat different than the others, due in part to the main deployment being of a different reactor technology (GCRs). The UK is also now considering new reactors, primarily as replacements for the existing fleet, but using PWRs and possible SMRs.

Russia and Ukraine exhibit the second theme of a major event impacting the nuclear power program. In this case, members of the former Soviet Union were experiencing generally good construction performance $^{\mathrm{mm}}$ followed by a very sharp increase in construction duration ${ }^{\mathrm{nn}}$ and a stoppage of new projects when the Soviet Union disbanded. The driving event was not related to nuclear power, but the resulting political and economic impacts sharply reduced the ability to finance and execute major construction programs while also reducing energy demand. The impacts of the triggering event needed to be worked through before recovery could occur. In the timeframe graphed, only Russia shows resumption of construction as its economy recovered, though Ukraine also has plans for new reactors. The limited construction in both cases is primarily for replacement reactors.

The third group, composed of India, Japan and South Korea, shows no significant change in construction duration or a general downward trend with no major gaps ${ }^{\circ 0}$ but the timeframe does not include postFukushima. This pattern should be compared to the first group. Current performance in Japan is not part of this pattern and Japan going forward is more likely to shift to the pattern of the first or second groups due to (1) worsening public opinion and safety concerns and (2) a major program disruptive event.

China is the only representative of the fourth theme shown ${ }^{\mathrm{pp}}$. The pattern includes a sharp increase in the number of new constructions with generally consistent or improving construction durations.

\footnotetext{
$\mathrm{mm}$ Bulgaria is an exception with reactor construction projects trending more like the West.

nn To display all graphs on the same scale, one Russian project started in 1986 with a duration of 303 months is not shown.

${ }^{\text {oo }}$ The high outlier in 2002 on the India graph is their first large LWR (a VVER) and first foreign vendor (Russia) since the 1960s.

pp The high outlier in 2000 on the China graph is the China Experimental Fast Reactor.
} 
Looking forward, Indian is planning to shift into a more expansive mode and may begin to look more like China, if construction performance continues. At the same time, the consistent performance in China and the lengthening duration of their program is resulting in a pattern more similar to the historic performance in South Korea and pre-Fukushima Japan.

Rapidly growing programs represent the most vibrant markets for new construction and also indicate growth areas going forward for fuel cycle and operational services. Programs with consistent construction performance are the most likely sources of market leaders going forward, while programs that are stagnant or worsening are more likely to lose current leadership positions. Programs in phase-out will need fewer fuel cycle services, but will have greater decommissioning needs.

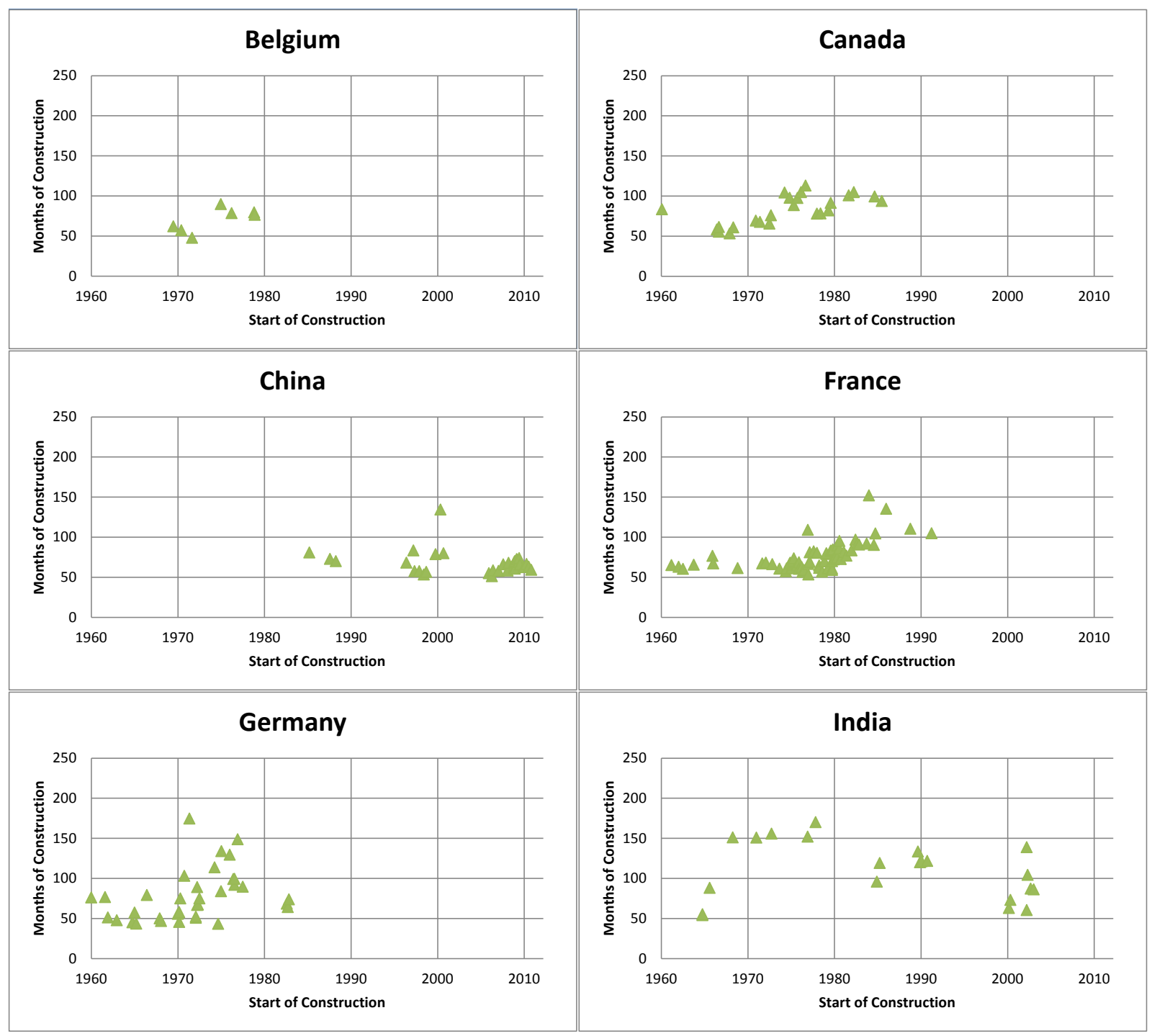




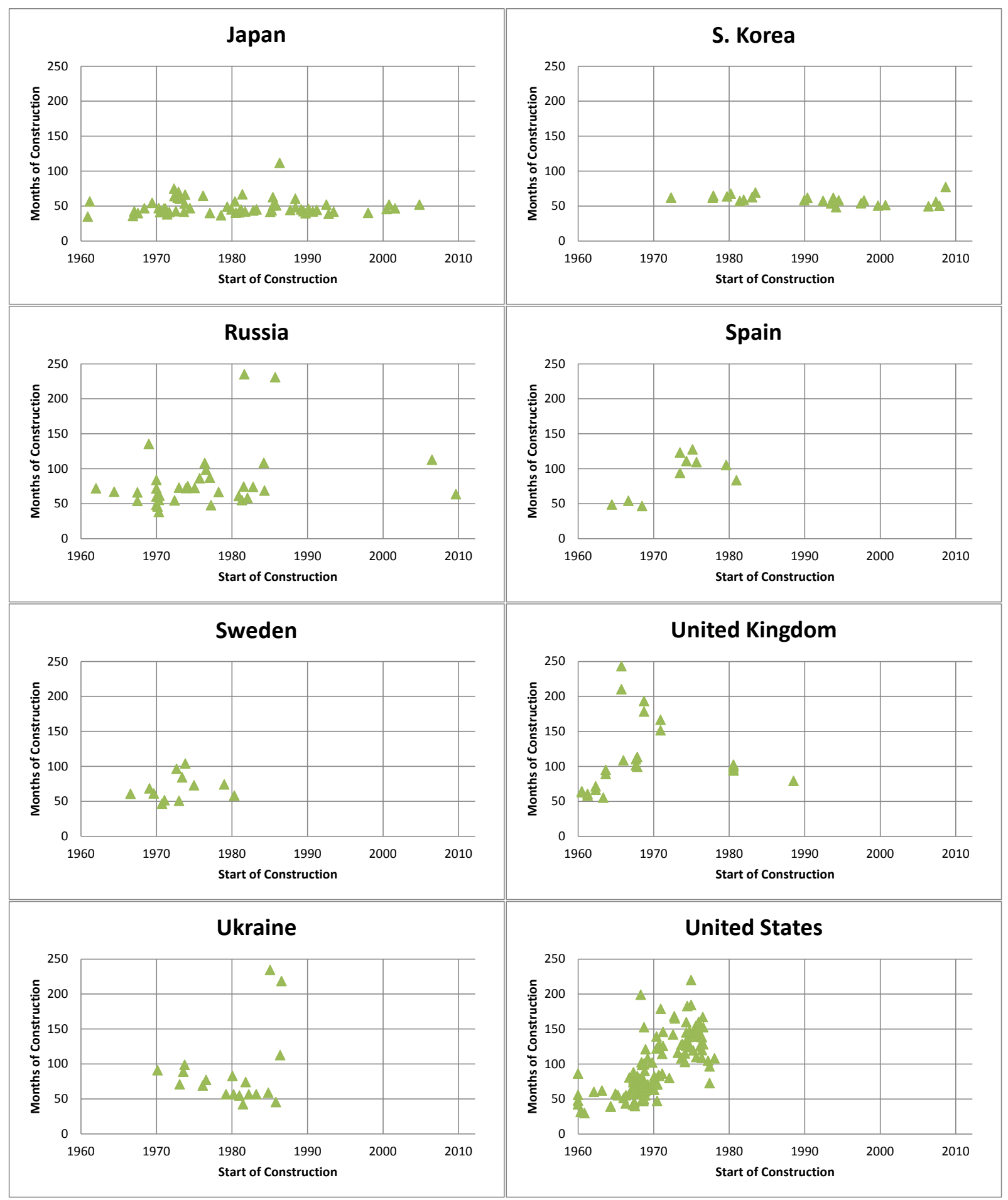

Figure 2 - Reactor construction start year versus duration in fourteen countries 


\section{Appendix B - Data Tables}

\section{B-1. Information on current global non-reactor fuel cycle facilities and associated companies}

Green rows indicate operating facilities while white rows are facilities under construction or being commissioned.

\begin{tabular}{|c|c|c|c|c|c|c|}
\hline $\begin{array}{l}\text { Host } \\
\text { Country }\end{array}$ & Facility Name & Facility/Fuel Type & $\begin{array}{c}\text { Facility } \\
\text { Status (As of } \\
\text { 9/2/2015 IAEA) }\end{array}$ & Design Capacity & $\begin{array}{c}\text { Parent } \\
\text { Company (or } \\
\text { Majority Owner) }\end{array}$ & $\begin{array}{l}\text { Start } \\
\text { of Ops }\end{array}$ \\
\hline Argentina & Arroyito HW Production Facility & Heavy Water Production & In operation & 200 t/year & CNEA - Argentina & 1993 \\
\hline Argentina & Cordoba Conversion Facility & Conversion to $\mathrm{UO} 2$ & In operation & 175 t HM/year & CNEA - Argentina & 1982 \\
\hline Argentina & $\begin{array}{l}\text { Ezeiza - Nuclear Fuel Manufacture } \\
\text { Plant }\end{array}$ & Fuel Fabrication (U Assembly) & In operation & 270 t HM/year & CNEA - Argentina & 1982 \\
\hline Argentina & Ezeiza - Special Alloy Fabrication & Zirconium Alloy Production & In operation & $10 \mathrm{t} /$ year & CNEA - Argentina & 1987 \\
\hline Argentina & Ezeiza - Special Alloy Fabrication & Zirconium Alloy Tubing & In operation & $300 \mathrm{~km} /$ year & CNEA - Argentina & 1987 \\
\hline Argentina & Pilcaniyeu Conversion Facility & Conversion to UF6 & In operation & $62 \mathrm{t} \mathrm{HM} /$ year & CNEA - Argentina & 1984 \\
\hline Belgium & $\underline{\text { FBFC International - MOX }}$ & $\begin{array}{l}\text { Fuel Fabrication (MOX } \\
\text { Assembly) }\end{array}$ & In operation & 100 t HM/year & AREVA & 1997 \\
\hline Brazil & INB - Fabrica de Combustivel Nuclear & Re-conversion to UO2 Powder & In operation & 120 t HM/year & INB - Brazil & 2000 \\
\hline Brazil & INB - FCN Resende - Unit 1 & Fuel Fabrication (U Assembly) & In operation & 240 t HM/year & INB - Brazil & 1982 \\
\hline Brazil & INB - Resende Enrichment Plant & Uranium Enrichment & $\begin{array}{l}\text { Commissioning } \\
\text { qq }\end{array}$ & $120 \mathrm{MTSWU} /$ year & INB - Brazil & 2005 \\
\hline Canada & Cameco - Blind River (UO3) & Conversion to UO3 & In operation & 18000 t HM/year & Cameco & 1983 \\
\hline Canada & Cameco - Port Hope (U) & Conversion to U Metal & In operation & 2000 t HM/year & Cameco & 1985 \\
\hline Canada & $\underline{\text { Cameco - Port Hope (UF6) }}$ & Conversion to UF6 & In operation & 12500 t HM/year & Cameco & 1984 \\
\hline Canada & Cameco - Port Hope (UO2) & Conversion to UO2 & In operation & 2800 t HM/year & Cameco & 1980 \\
\hline Canada & $\begin{array}{l}\text { General Electric Canada Inc. - } \\
\text { Arnprior }\end{array}$ & Zirconium Alloy Tubing & In operation & $1350 \mathrm{~km} /$ year & GE-Hitachi & 1981 \\
\hline Canada & N. Fuel PLLT. OP. - Toronto & Fuel Fabrication (U Pellet-Pin) & In operation & 1300 t HM/year & GE-Hitachi & 1967 \\
\hline Canada & $\begin{array}{l}\text { Nuclear Product Department - } \\
\text { Cobourgh }\end{array}$ & Zirconium Alloy Tubing & In operation & $950 \mathrm{~km} /$ year & Cameco & 1976 \\
\hline Canada & Peterborough Facility & Fuel Fabrication (U Assembly) & In operation & 1200 t HM/year & GE-Hitachi & 1956 \\
\hline
\end{tabular}

qq The completion of the first stage of the plant (114,000 SWU/year) has been postponed from 2008 to 2010 for budgetary restrictions. Stage 2 will take capacity to 200 MTSWU/year. 


\begin{tabular}{|c|c|c|c|c|c|c|}
\hline $\begin{array}{l}\text { Host } \\
\text { Country }\end{array}$ & Facility Name & Facility/Fuel Type & $\begin{array}{c}\text { Facility } \\
\text { Status (As of } \\
\text { 9/2/2015 IAEA) }\end{array}$ & Design Capacity & $\begin{array}{c}\text { Parent } \\
\text { Company (or } \\
\text { Majority Owner) }\end{array}$ & $\begin{array}{c}\text { Start } \\
\text { of Ops }\end{array}$ \\
\hline Canada & Zircatec Precision Ind. - Port Hope & Fuel Fabrication (U Assembly) & In operation & 1200 t HM/year & $\underline{\text { Cameco }}$ & 1964 \\
\hline China & CANDU Fuel Plant & Fuel Fabrication (U Assembly) & In operation & 200 t HM/year & Joint Venture & 2003 \\
\hline China & $\underline{\text { Lanzhou }}$ & Conversion to UF6 & In operation & 3000 t HM/year & CNNC - China & 1980 \\
\hline China & Lanzhou 2 & Uranium Enrichment & In operation & $500 \mathrm{MTSWU} /$ year & CNNC - China & 2005 \\
\hline China & Shaanxi Uranium Enrichment Plant & Uranium Enrichment & In operation & 1000 MTSWU/year & CNNC - China & 1997 \\
\hline China & Yibin Nuclear Fuel Element Plant & Fuel Fabrication (U Assembly) & In operation & 400 t HM/year & CNNC - China & 1998 \\
\hline France & AREVA NC La Hague - UP2-800 & Spent Fuel Reprocessing & In operation & 1000 t HM/year & AREVA & 1996 \\
\hline France & AREVA NC La Hague - UP3 & Spent Fuel Reprocessing & In operation & 1000 t HM/year & AREVA & 1990 \\
\hline France & AREVA NC Melox & Fuel Fabrication (MOX) & In operation & 195 t HM/year & AREVA & 1995 \\
\hline France & AREVA NC TU5 & Re-Conversion to U308 (Rep. U) & In operation & 1600 t HM/year & AREVA & 1995 \\
\hline France & AREVA NC W Plant & Re-Conversion to U308 (Dep. U) & In operation & 20000 t HM/year & AREVA & 1984 \\
\hline France & CEZUS - Jarrie & Zirconium Alloy Production & In operation & $2200 \mathrm{t} /$ year & AREVA & 1982 \\
\hline France & CEZUS - Montreuil Juigné & Zirconium Alloy Tubing & In operation & $1200 \mathrm{t} /$ year & AREVA & 1982 \\
\hline France & CEZUS - Paimboeuf & Zirconium Alloy Tubing & In operation & $5000 \mathrm{~km} /$ year & AREVA & 1981 \\
\hline France & CEZUS - Rugles & Zirconium Alloy Production & In operation & $600 \mathrm{t} /$ year & AREVA & 1981 \\
\hline France & CEZUS - Ugine & Zirconium Alloy Production & In operation & 2200 t/year & AREVA & 1982 \\
\hline France & Comurhex II - Malvesi (UF4) & Conversion to UF4 & Construction & 15000 t HM/year & AREVA & 2018 \\
\hline France & Comurhex II - Pierrelatte (UF6) & Conversion to UF6 & Construction & 15000 t HM/year & AREVA & 2018 \\
\hline France & Comurhex Malvesi (UF4) & Conversion to UF4 & In operation & 14000 t HM/year & AREVA & 1959 \\
\hline France & Comurhex Pierrelatte (UF6) & Conversion to UF6 & In operation & 14000 t HM/year & AREVA & 1961 \\
\hline France & FBFC-Romans & Fuel Fabrication (U Assembly) & In operation & 1400 t HM/year & AREVA & 1979 \\
\hline France & Georges Besse II & Uranium Enrichment & In operation & 7500 MTSWU/year & AREVA & 2011 \\
\hline Germany & $\begin{array}{l}\text { Advanced Nuclear Fuels GmbH } \\
\text { Duisburg Plant }\end{array}$ & Zirconium Alloy Tubing & In operation & $2100 \mathrm{~km} /$ year & AREVA & 1981 \\
\hline Germany & $\begin{array}{l}\text { Advanced Nuclear Fuels GmbH } \\
\text { Karlstein Plant }\end{array}$ & Fuel Assembly Component & In operation & Unknown & AREVA & 1969 \\
\hline Germany & $\begin{array}{l}\text { Advanced Nuclear Fuels GmbH Lingen } \\
\text { Plant }\end{array}$ & Fuel Fabrication (U Assembly) & In operation & 650 t HM/year & AREVA & 1979 \\
\hline Germany & $\underline{\text { Urenco Germany GmbH }}$ & Uranium Enrichment & In operation & 4500 MTSWU/year & URENCO Ltd & 1985 \\
\hline India & Baroda & Heavy Water Production & In operation & $17 \mathrm{t} /$ year & $\underline{D A E}$ - India & 1977 \\
\hline India & Hazira & Heavy Water Production & In operation & $80 \mathrm{t} /$ year & $\underline{D A E}$ - India & 1991 \\
\hline India & Kota & Heavy Water Production & In operation & $85 \mathrm{t} /$ year & $\underline{D A E}$ - India & 1985 \\
\hline India & Manuguru & Heavy Water Production & In operation & $185 \mathrm{t} /$ year & $\underline{\text { DAE - India }}$ & 1991 \\
\hline
\end{tabular}




\begin{tabular}{|c|c|c|c|c|c|c|}
\hline $\begin{array}{l}\text { Host } \\
\text { Country }\end{array}$ & Facility Name & Facility/Fuel Type & $\begin{array}{c}\text { Facility } \\
\text { Status (As of } \\
\text { 9/2/2015 IAEA) }\end{array}$ & Design Capacity & $\begin{array}{c}\text { Parent } \\
\text { Company (or } \\
\text { Majority Owner) }\end{array}$ & $\begin{array}{c}\text { Start } \\
\text { of Ops }\end{array}$ \\
\hline India & $\underline{N F C-(Z I R)}$ & Zirconium Alloy Production & In operation & $250 \mathrm{t} /$ year & $\underline{\mathrm{DAE}}$ - India & 1980 \\
\hline India & NFC (BWR) & Fuel Fabrication (U Assembly) & In operation & $24 \mathrm{t} \mathrm{HM} /$ year & $\underline{D A E}$ - India & 1974 \\
\hline India & NFC - (PHWR) - Block-A & Fuel Fabrication (U Assembly) & In operation & 300 t HM/year & $\underline{D A E}$ - India & 1974 \\
\hline India & NFC - Hyderabad (ZSP) & Zirconium Alloy Tubing & In operation & 180 t/year & $\underline{\mathrm{DAE} \text { - India }}$ & 1971 \\
\hline India & NFC (NZFP) & Zirconium Alloy Tubing & In operation & $59 \mathrm{t} /$ year & DAE - India & 1987 \\
\hline India & NFC (NZSP) & Zirconium Alloy Production & In operation & 250 t/year & $\underline{\mathrm{DAE} \text { - India }}$ & \\
\hline India & NFC (PELLET) & Fuel Fabrication (U Pellet-Pin) & In operation & 335 t HM/year & $\underline{\mathrm{DAE} \text { - India }}$ & 1998 \\
\hline India & NFC (PHWR)-2 & Fuel Fabrication (U Assembly) & In operation & 300 t HM/year & $\underline{\mathrm{DAE} \text { - India }}$ & 1997 \\
\hline India & NFC (UOP) - Block-A & Conversion to $\mathrm{UO} 2$ & In operation & 450 t HM/year & $\underline{D A E}$ - India & 1972 \\
\hline India & $\underline{\mathrm{NFC}}(\mathrm{ZFP})$ & Zirconium Alloy Tubing & In operation & $80 \mathrm{t} /$ year & $\underline{D A E}$ - India & 1973 \\
\hline India & $\underline{\text { Thal - Vaishet }}$ & Heavy Water Production & In operation & $78 \mathrm{t} /$ year & $\underline{\mathrm{DAE} \text { - India }}$ & 1987 \\
\hline India & Tuticorin & Heavy Water Production & In operation & $49 \mathrm{t} /$ year & $\underline{D A E}$ - India & 1978 \\
\hline Japan & $\begin{array}{l}\text { Global Nuclear Fuel-Japan Co. Ltd. } \\
\text { (GNF-J) }\end{array}$ & Fuel Fabrication (U Assembly) & In operation & 750 t HM/year & GNFJ - Japan & 1970 \\
\hline Japan & $\begin{array}{l}\text { Mitsubishi Materials Corporation - } \\
\text { Okegawa Plant }\end{array}$ & Zirconium Alloy Tubing & In operation & $800 \mathrm{~km} /$ year & MMC - Japan & 1973 \\
\hline Japan & Mitsubishi Nuclear Fuel Ltd. (MNF) & Fuel Fabrication (U Assembly) & In operation & 440 t HM/year & Joint Venture & 1972 \\
\hline Japan & Mitsubushi Nuclear Fuel Ltd. & Re-conversion to UO2 Powder & In operation & 450 t HM/year & Joint Venture & 1972 \\
\hline Japan & $\begin{array}{l}\text { Nuclear Fuel Industry Ltd. (NFI } \\
\text { Kumatori) }\end{array}$ & Fuel Fabrication (U Assembly) & In operation & 284 t HM/year & Joint Venture & 1972 \\
\hline Japan & Nuclear Fuel Industry Ltd. (NFI Tokai) & Fuel Fabrication (U Assembly) & In operation & 200 t HM/year & Joint Venture & 1980 \\
\hline Japan & Rokkasho Reprocessing Plant & Spent Fuel Reprocessing & Commissioning & 800 t HM/year & Joint Venture & 2007 \\
\hline Japan & Rokkasho Uranium Enrichment Plant & Uranium Enrichment & In operation & $1050 \mathrm{MTSWU} /$ year & Joint Venture & 1992 \\
\hline Japan & Zirco Products Chofu-kita & Zirconium Alloy Tubing & In operation & $1400 \mathrm{~km} /$ year & $\underline{\text { NSSMC - Japan }}$ & 2000 \\
\hline Kazakhstan & Ulba Metalurgical Plant (UMP) & Fuel Fabrication (U Pellet-Pin) & In operation & 2800 t HM/year & Kazakhstan - Gov & 1949 \\
\hline Korea, So. & CANDU Fuel Fabrication Plant (2) & Fuel Fabrication (U Assembly) & In operation & 400 t HM/year & Korea, So - Gov & 1998 \\
\hline Korea, So. & PWR Fuel Fabrication Plant & Fuel Fabrication (U Assembly) & In operation & 400 t HM/year & Korea, So - Gov & 1989 \\
\hline Netherlands & $\underline{\text { Urenco Nederland }}$ & Uranium Enrichment & In operation & $4500 \mathrm{MTSWU} /$ year & $\underline{\text { URENCO Ltd }}$ & 1973 \\
\hline Pakistan & Chashma & Fuel Fabrication (U Assembly) & In operation & 20 t HM/year & PAEC - Pakistan & 1986 \\
\hline Pakistan & Kahuta & Uranium Enrichment & In operation & 5 MTSWU/year & PAEC - Pakistan & 1984 \\
\hline Romania & $\begin{array}{l}\text { Nuclear Fuel Plant Subsidiary Pitesti } \\
\text { (FCN Pitesti) }\end{array}$ & Fuel Fabrication (U Assembly) & In operation & 200 t HM/year & $\underline{\text { SNN - Romania }}$ & 1983 \\
\hline Russia & Angarsk & Conversion to UF6 & In operation & 20000 t HM/year & Rosatom - Russia & 1954 \\
\hline Russia & Angarsk & Uranium Enrichment & In operation & $2600 \mathrm{MTSWU} /$ year & Rosatom - Russia & 1954 \\
\hline
\end{tabular}




\begin{tabular}{|c|c|c|c|c|c|c|}
\hline $\begin{array}{l}\text { Host } \\
\text { Country }\end{array}$ & Facility Name & Facility/Fuel Type & $\begin{array}{c}\text { Facility } \\
\text { Status (As of } \\
\text { 9/2/2015 IAEA) }\end{array}$ & Design Capacity & $\begin{array}{c}\text { Parent } \\
\text { Company (or } \\
\text { Majority Owner) }\end{array}$ & $\begin{array}{c}\text { Start } \\
\text { of Ops }\end{array}$ \\
\hline Russia & Chepetski Machine Plant - Zircaloy & Zirconium Alloy Tubing & In operation & 650 t/year & Rosatom - Russia & 1951 \\
\hline Russia & Chepetski Machine Plant- & Conversion to UF4 & In operation & $2000 \mathrm{t} /$ year & Rosatom - Russia & 1951 \\
\hline Russia & Ekaterinburg (Sverdlovsk-44) & Conversion to UF6 & In operation & 4000 t HM/year & Rosatom - Russia & 1949 \\
\hline Russia & Ekaterinburg (Sverdlovsk-44) & Uranium Enrichment & In operation & $10000 \mathrm{MTSWU} /$ year & Rosatom - Russia & 1949 \\
\hline Russia & Krasnoyarsk & Uranium Enrichment & In operation & $8700 \mathrm{MTSWU} /$ year & Rosatom - Russia & 1964 \\
\hline Russia & Machine - Building Plant (FBR) & Fuel Fabrication (U Assembly) & In operation & 50 t HM/year & Rosatom - Russia & 1953 \\
\hline Russia & Machine - Building Plant (LWR) & Fuel Fabrication (U Assembly) & In operation & 950 t HM/year & Rosatom - Russia & 1953 \\
\hline Russia & Machine - Building Plant (Pellets) & Fuel Fabrication (U Pellet-Pin) & In operation & 1100 t HM/year & Rosatom - Russia & 1953 \\
\hline Russia & Machine - Building Plant (RBMK) & Fuel Fabrication (U Assembly) & In operation & 460 t HM/year & Rosatom - Russia & 1953 \\
\hline Russia & $\begin{array}{l}\text { Novosibirsk Chemical Concentrates } \\
\text { Plant (Assembly) }\end{array}$ & Fuel Fabrication (U Assembly) & In operation & 1200 t HM/year & Rosatom - Russia & 1949 \\
\hline Russia & RT-1, Combined Mayak & Spent Fuel Reprocessing & In operation & 400 t HM/year & Rosatom - Russia & 1971 \\
\hline Russia & Siberian Chemical Combine (Seversk) & Uranium Enrichment & In operation & $3000 \mathrm{MTSWU} /$ year & Rosatom - Russia & 1950 \\
\hline Russia & $\underline{W-E C P}$ & Re-Conversion to U308 (Dep. U) & In operation & $\begin{array}{l}\text { 10,000 } \\
\text { MTSWU/year }\end{array}$ & Rosatom - Russia & 2009 \\
\hline Spain & Fabrica de combustible & Fuel Fabrication (U Assembly) & In operation & 400 t HM/year & Spain - Gov & 1985 \\
\hline Sweden & Sandvik Materials Technology & Zirconium Alloy Tubing & In operation & $1000 \mathrm{~km} /$ year & $\underline{\text { Sandvik Group }}$ & 1958 \\
\hline Sweden & Westinghouse Electric Sweden $A B$ & Fuel Fabrication (U Assembly) & In operation & 600 t HM/year & $\underline{\text { Toshiba }}$ & 1971 \\
\hline UK & NDA Magnox Reprocessing & Spent Fuel Reprocessing & In operation & 1500 t HM/year & NDA - UK & 1964 \\
\hline UK & NDA Thorp & Spent Fuel Reprocessing & In operation & 900 t HM/year & NDA - UK & 1994 \\
\hline UK & Springfields Enr. U Residue Recovery & Conversion to UO2 & In operation & $65 \mathrm{t} \mathrm{HM} /$ year & $\underline{\text { NDA - UK }}$ & 1985 \\
\hline UK & Springfields Main Line Chemical Plant & Conversion to UF4 & In operation & 10000 t HM/year & NDA - UK & 1960 \\
\hline UK & Springfields OFC AGR Line & Fuel Fabrication (U Assembly) & In operation & 290 t HM/year & NDA - UK & 1996 \\
\hline UK & Springfields OFC IDR UO2 Line & Conversion to UO2 & In operation & 550 t HM/year & NDA - UK & 1995 \\
\hline UK & Springfields OFC LWR Line & Fuel Fabrication (U Assembly) & In operation & 330 t HM/year & NDA - UK & 1996 \\
\hline UK & $\underline{\text { Urenco UK Ltd }}$ & Uranium Enrichment & In operation & 4000 MTSWU/year & URENCO Ltd & 1972 \\
\hline USA & Allens Park & Zirconium Alloy Tubing & In operation & $500 \mathrm{~km} /$ year & Unknown & 1981 \\
\hline USA & BWX Technology (BWXT) Fuel Facility & $\begin{array}{l}\text { Fuel Fabrication (Research } \\
\text { Reactors) }\end{array}$ & In operation & 100 t HM/year & $\begin{array}{l}\text { McDermott } \\
\text { International } \\
\end{array}$ & 1982 \\
\hline USA & Columbia (Westinghouse) & Fuel Fabrication (U Assembly) & In operation & 1150 t HM/year & Toshiba & 1986 \\
\hline USA & Kennewick & Zirconium Alloy Tubing & In operation & 2200 km/year & $\underline{\text { Sandvik Group }}$ & 1981 \\
\hline USA & Lynchburg - FC Fuels & Fuel Fabrication (U Assembly) & In operation & 400 t HM/year & AREVA & 1982 \\
\hline USA & Metropolis / Converdyn & Conversion to UF6 & In operation & 17600 t HM/year & Joint Venture & 1959 \\
\hline
\end{tabular}




\begin{tabular}{|c|c|c|c|c|c|c|}
\hline $\begin{array}{l}\text { Host } \\
\text { Country }\end{array}$ & Facility Name & Facility/Fuel Type & $\begin{array}{c}\text { Facility } \\
\text { Status (As of } \\
\text { 9/2/2015 IAEA) }\end{array}$ & Design Capacity & $\begin{array}{c}\text { Parent } \\
\text { Company (or } \\
\text { Majority Owner) }\end{array}$ & $\begin{array}{c}\text { Start } \\
\text { of Ops }\end{array}$ \\
\hline USA & MOX Fuel Fabrication Facility (MFFF) & Fuel Fabrication (MOX) & Construction & $61.5 \mathrm{t}$ & DOE - USA - Gov & 2016 \\
\hline USA & Paducah & Re-conversion to UO2 Powder & In operation & 18000 t HM/year & Unknown & 2010 \\
\hline USA & Portsmouth & Re-conversion to UO2 Powder & In operation & 13500 t HM/year & Unknown & 2010 \\
\hline USA & Richland (ANF) & Fuel Fabrication (U Assembly) & In operation & 700 t HM/year & AREVA & 1970 \\
\hline USA & Urenco USA & Uranium Enrichment & In operation & 3000 MTSWU/year & $\underline{\text { URENCO Ltd }}$ & 2010 \\
\hline USA & Wah Chang - Albany & Zirconium Alloy Production & In operation & $2000 \mathrm{t} /$ year & ATI - USA & 1956 \\
\hline USA & Western Zirconium & Zirconium Alloy Production & In operation & $1350 \mathrm{t} /$ year & Toshiba & 1980 \\
\hline USA & Wilmington & Zirconium Alloy Tubing & In operation & $2200 \mathrm{~km} /$ year & GE-Hitachi & 1981 \\
\hline USA & Wilmington (GNF) & Fuel Fabrication (U Assembly) & In operation & 1200 t HM/year & GE-Hitachi & 1982 \\
\hline
\end{tabular}

\section{B-2. Information on global reactors under construction}

\begin{tabular}{|c|c|c|c|c|c|c|c|c|c|}
\hline $\begin{array}{c}\frac{\text { NPP }}{\text { Location }} \\
\text { Country }\end{array}$ & $\begin{array}{c}\text { Planned } \\
\text { Operation } \\
\text { Date }\end{array}$ & $\begin{array}{c}\text { Date } \\
\text { Started } \\
\text { Construction }\end{array}$ & Reactor Name & Type & Design/ Model & MWe & Operator & Reactor Supplier & $\begin{array}{c}\text { Supplier } \\
\text { Country } \\
\text { (Ownership) }\end{array}$ \\
\hline Argentina & 2018 & $2 / 8 / 2014$ & Carem-25 & PWR & CAREM Prototype & 29 & CNEA & CNEA & Argentina \\
\hline Belarus & 2016 & $11 / 6 / 2013$ & Belarusian-1 & PWR & VVER V-491 & 1109 & BelNPP & Atomstroyexport & Russia \\
\hline Belarus & 2018 & $4 / 26 / 2014$ & Belarusian-2 & PWR & VVER V-491 & 1109 & BelNPP & Atomstroyexport & Russia \\
\hline Brazil & & $6 / 1 / 2010$ & Angra-3 & PWR & Pre Konvoi & 1245 & ELETRONU & AREVA & France \\
\hline China & Start-up & $11 / 21 / 2010$ & Changjiang-2 & PWR & CNP-600 & 650 & HNPC & DEC / CNNC & China \\
\hline China & 2016 & $12 / 23 / 2010$ & Fangchenggang-2 & PWR & CPR-1000 & 1080 & GFNPC & $\mathrm{DEC} / \mathrm{CGN}$ & China \\
\hline China & 2016 & $12 / 24 / 2015$ & Fangchenggang-3 & PWR & Hualong One & 1080 & GFNPC & $\mathrm{DEC} / \mathrm{CGN}$ & China \\
\hline China & 2016 & $12 / 31 / 2010$ & Fuqing-3 & PWR & CPR-1000 & 1080 & FSNPC & NPIC / CNNC & China \\
\hline China & 2017 & $11 / 17 / 2012$ & Fuqing-4 & PWR & CPR-1000 & 1080 & FSNPC & NPIC / CNNC & China \\
\hline China & 2019 & $5 / 7 / 2015$ & Fuqing-5 & PWR & Hualong One & 1150 & FSNPC & NPIC / CNNC & China \\
\hline China & 2020 & $12 / 22 / 2015$ & Fuqing- 6 & PWR & Hualong One & 1150 & FSNPC & NPIC / CNNC & China \\
\hline China & 2015 & $9 / 24 / 2009$ & Haiyang-1 & PWR & AP1000 & 1250 & SNPC & WH / CNEC & Japan \\
\hline China & 2016 & $6 / 20 / 2010$ & Haiyang-2 & PWR & AP1000 & 1250 & SNPC & WH / CNEC & Japan \\
\hline China & Start-up & $8 / 15 / 2009$ & Hongyanhe-4 & PWR & CPR-1000 & 1080 & LHNPC & DEC / CNEC & China \\
\hline
\end{tabular}




\begin{tabular}{|c|c|c|c|c|c|c|c|c|c|}
\hline$\frac{\frac{\text { NPP }}{\text { Location }}}{\text { Country }}$ & $\begin{array}{c}\text { Planned } \\
\text { Operation } \\
\text { Date }\end{array}$ & $\begin{array}{c}\text { Date } \\
\text { Started } \\
\text { Construction }\end{array}$ & Reactor Name & Type & Design/ Model & MWe & Operator & Reactor Supplier & $\begin{array}{c}\text { Supplier } \\
\text { Country } \\
\text { (Ownership) }\end{array}$ \\
\hline China & 2019 & $\underline{3 / 29 / 2015}$ & Hongyanhe-5 & PWR & ACPR-1000 & 1080 & LHNPC & $\mathrm{DEC} / \mathrm{CNEC}$ & China \\
\hline China & & $7 / 24 / 2015$ & Hongyanhe-6 & PWR & ACPR-1000 & 1000 & LHNPC & DEC / CNEC & China \\
\hline China & Start-up & $9 / 29 / 2010$ & Ningde-4 & PWR & CPR-1000 & 1080 & NDNP & CFHI / CNNC & China \\
\hline China & 2016 & $4 / 19 / 2009$ & Sanmen-1 & PWR & AP1000 & 1250 & SNPC & $\mathrm{MHI} / \mathrm{WH}$ & Japan \\
\hline China & 2016 & $12 / 15 / 2009$ & Sanmen-2 & PWR & AP1000 & 1250 & SNPC & $\mathrm{MHI} / \mathrm{WH}$ & Japan \\
\hline China & 2017 & $\underline{12 / 9 / 2012}$ & Shidao Bay-1 & $\underline{\mathrm{HTGR}}$ & HTR-PM & 210 & HSNPC & INET/CNEC/CNEC & China \\
\hline China & 2019 & Pending ${ }^{r r}$ & Shidaowan-1 & PWR & CAP-1400 & 1400 & HSNPC & SNPTC & China \\
\hline China & 2020 & Pending & Shidaowan-2 & PWR & CAP-1400 & 1400 & HSNPC & SNPTC & China \\
\hline China & 2017 & $11 / 18 / 2009$ & Taishan-1 & PWR & EPR-1750 & 1700 & TNPC & AREVA / EDF & France \\
\hline China & 2017 & $4 / 15 / 2010$ & Taishan-2 & PWR & EPR-1750 & 1700 & TNPC & AREVA / EDF & France \\
\hline China & $2 / 2018$ & $12 / 27 / 2012$ & Tianwan-3 & PWR & VVER V-428M & 1060 & JNPC & IZ / JNPC & China \\
\hline China & $12 / 2018$ & $9 / 27 / 2013$ & Tianwan-4 & PWR & VVER-1000 & 1060 & JNPC & Rosatom & Russia \\
\hline China & & $12 / 27 / 2015$ & Tianwan-5 & PWR & ACPR-1000 & 1080 & JNPC & CGN & China \\
\hline China & 2017 & $11 / 17 / 2012$ & Yangjiang-4 & PWR & CPR-1000 & 1080 & YJNPC & CFHI / CNEC & China \\
\hline China & 2018 & $9 / 18 / 2013$ & Yangjiang-5 & PWR & ACPR-1000 & 1086 & YJNPC & CFHI / CNEC & China \\
\hline China & 2019 & $12 / 23 / 2013$ & Yangjiang- 6 & PWR & ACPR-1000 & 1086 & YJNPC & CFHI / CNEC & China \\
\hline Finland & 2018 & $8 / 12 / 2005$ & Olkiluoto-3 & PWR & EPR & 1720 & TVO & AREVA & France \\
\hline France & 2019 & $12 / 3 / 2007$ & Flamanville 3 & PWR & EPR & 1750 & EDF & AREVA & France \\
\hline$\underline{\text { India }}$ & 2015 & $11 / 22 / 2010$ & Kakrapar-3 & PHWR & PHWR-700 & 700 & NPCIL & BHEL & India \\
\hline India & 2016 & $11 / 22 / 2010$ & Kakrapar-4 & PHWR & PHWR-700 & 700 & NPCIL & BHEL & India \\
\hline India & 2016 & $10 / 23 / 2004$ & Kalpakkam-1 & PFBR & Prototype FBR & 500 & BNVN & BNVN & India \\
\hline India & 2016 & $7 / 4 / 2002$ & Kudankulam-2 & PWR & VVER V-412 & 1000 & NPCIL & Rosatom & Russia \\
\hline
\end{tabular}

${ }^{\text {rr }}$ Non-nuclear construction started in 2014, but nuclear construction has been delayed for these first CAP-1400s 


\begin{tabular}{|c|c|c|c|c|c|c|c|c|c|}
\hline $\begin{array}{c}\frac{\text { NPP }}{\text { Location }} \\
\text { Country }\end{array}$ & $\begin{array}{l}\text { Planned } \\
\text { Operation } \\
\text { Date }\end{array}$ & $\begin{array}{c}\text { Date } \\
\text { Started } \\
\text { Construction }\end{array}$ & Reactor Name & Type & Design/ Model & MWe & Operator & Reactor Supplier & $\begin{array}{c}\text { Supplier } \\
\text { Country } \\
\text { (Ownership) }\end{array}$ \\
\hline India & 2016 & $7 / 18 / 2011$ & Rajasthan-7 & PHWR & Horizontal Pressure Tube & 700 & NPCIL & $\mathrm{HCC}$ & India \\
\hline India & 2016 & $9 / 30 / 2011$ & Rajasthan-8 & PHWR & HPT Type & 700 & NPCIL & $\mathrm{HCC}$ & India \\
\hline Japan & 2022 & $10 / 12 / 2007$ & Ohma-1 & BWR & ABWR & 1383 & EPDC & GEH & Japan / USA \\
\hline Japan & 2016 & $5 / 7 / 2010$ & $\underline{\text { Shimane-3 }}$ & BWR & ABWR & 1325 & CHUGOKU & GEH & Japan / USA \\
\hline So. Korea & 2017 & $7 / 10 / 2012$ & Shin-Hanul-1 & PWR & APR-1400 & 1400 & KHNP & DOOSAN & So. Korea \\
\hline So. Korea & 2018 & $6 / 19 / 2013$ & Shin-Hanul-2 & PWR & APR-1400 & 1400 & KHNP & DOOSAN & So. Korea \\
\hline So. Korea & Start-up & $10 / 16 / 2008$ & Shin-Kori-3 ss & PWR & APR-1400 & 1400 & KHNP & DOOSAN & So. Korea \\
\hline So. Korea & 2016 & $8 / 19 / 2009$ & Shin-Kori-4 & PWR & APR-1400 & 1400 & KHNP & DOOSAN & So. Korea \\
\hline Pakistan & $12 / 1 / 2016$ & $5 / 28 / 2011$ & Chasnupp-3 & PWR & CNP-300 & 340 & PAEC & CZEC & China \\
\hline Pakistan & $10 / 1 / 2017$ & $12 / 18 / 2011$ & Chasnupp-4 & PWR & CNP-300 & 340 & PAEC & CZEC & China \\
\hline Pakistan & & $8 / 21 / 2015$ & Karachi Coastal-1 & PWR & Hualong One & 1150 & PAEC & & China \\
\hline Pakistan & & $\underline{8 / 21 / 2015}$ & Karachi Coastal-2 & PWR & Hualong One & 1150 & PAEC & & China \\
\hline Russia & $12 / 31 / 2019$ & $4 / 15 / 2007$ & Adademik Lomonosov-1 & PWR & KLT-40S Floating & 35 & REA & Rosatom & Russia \\
\hline Russia & $12 / 31 / 2019$ & $4 / 15 / 2007$ & Akademik Lomonosov-2 & PWR & KLT-40S Floating & 35 & REA & Rosatom & Russia \\
\hline Russia & $12 / 1 / 2019$ & $2 / 22 / 2012$ & Baltic-1 (Kaliningrad) & PWR & VVER V-491 & 1200 & REA & Rosatom & Russia \\
\hline Russia & Start-up & $7 / 18 / 2006$ & Beloyarsk-4 ${ }^{\mathrm{tt}}$ & FBR & $\mathrm{BN}-800$ & 880 & REA & Rosatom & Russia \\
\hline Russia & 2016 & $10 / 25 / 2008$ & Leningrad II-1 & PWR & VVER V-491 & 1085 & REA & Rosatom & Russia \\
\hline Russia & 2018 & $4 / 15 / 2010$ & Leningrad II-2 & PWR & VVER V-491 & 1085 & REA & Rosatom & Russia \\
\hline Russia & 2014 & $6 / 24 / 2008$ & Novovoronezh II-1 & PWR & VVER V-392M & 1114 & REA & Rosatom & Russia \\
\hline Russia & 2015 & $7 / 12 / 2009$ & Novovoronezh II-2 & PWR & VVER V-392M & 1114 & REA & Rosatom & Russia \\
\hline Russia & 2017 & $6 / 16 / 2010$ & Rostov-4 & PWR & VVER V-320 & 1011 & REA & Rosatom & Russia \\
\hline
\end{tabular}

ss In start-up, connected to grid on $\underline{1 / 15 / 2016}$

tt In extended testing/start-up, first connected to grid on 12/10/15 


\begin{tabular}{|c|c|c|c|c|c|c|c|c|c|}
\hline $\begin{array}{c}\frac{\text { NPP }}{\text { Location }} \\
\text { Country }\end{array}$ & $\begin{array}{c}\text { Planned } \\
\text { Operation } \\
\text { Date }\end{array}$ & $\begin{array}{c}\text { Date } \\
\text { Started } \\
\text { Construction }\end{array}$ & Reactor Name & Type & Design/ Model & MWe & Operator & Reactor Supplier & $\begin{array}{c}\text { Supplier } \\
\text { Country } \\
\text { (Ownership) }\end{array}$ \\
\hline Slovakia & $11 / 9 / 2016$ & $1 / 27 / 1987$ & Mochovce-3 & PWR & VVER V-213 & 471 & SEAS & SKODA & Russia \\
\hline Slovakia & $12 / 31 / 2017$ & $1 / 27 / 1987$ & Mochovce-4 & PWR & VVER V-213 & 471 & SEAS & SKODA & Russia \\
\hline Taiwan & 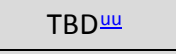 & $3 / 31 / 1999$ & Lungmen-1 & ABWR/BWR & & 1300 & TPC & $\mathrm{GE}$ & USA \\
\hline Taiwan & TBD & $8 / 30 / 1999$ & Lungmen-2 & ABWR/BWR & & 1300 & TPC & GE & USA \\
\hline$\underline{\mathrm{UAE}}$ & $6 / 2 / 2017$ & $7 / 18 / 2012$ & Barakah-1 & PWR & APR-1400 & 1345 & ENEC & KEPCO & Korea \\
\hline UAE & 2017 & $5 / 28 / 2013$ & Barakah-2 & PWR & APR-1400 & 1345 & ENEC & KEPCO & Korea \\
\hline UAE & 2018 & $9 / 24 / 2014$ & Barakah-3 & PWR & APR-1400 & 1345 & ENEC & KEPCO & Korea \\
\hline UAE & 2020 & $7 / 30 / 2015$ & Barakah-4 & PWR & APR-1400 & 1400 & ENEC & KEPCO & Korea \\
\hline$\underline{\text { USA }}$ & Start-up & $9 / 1 / 1973$ & Watts Bar-2 & PWR & W(4-Loop) ICECND & 1218 & TVA & WH & Japan \\
\hline USA & 2017 & $3 / 9 / 2013$ & Summer-2 & PWR & AP1000 & 1200 & SCEG & WH & Japan \\
\hline USA & 2018 & $11 / 2 / 2013$ & Summer-3 & PWR & AP1000 & 1117 & SCEG & WH & Japan \\
\hline USA & 2016 & $3 / 12 / 2013$ & Vogtle-3 & PWR & AP1000 & 1200 & GEORGIA & WH & Japan \\
\hline USA & 2017 & $11 / 19 / 2013$ & Vogtle-4 & PWR & AP1000 & 1117 & GEORGIA & WH & Japan \\
\hline
\end{tabular}

uu The two Lungmen reactors are currently in a government-mandated 3-year suspended status with Lungmen-1 to be sealed once pre-operational safety checks are completed and construction suspended on Lungmen-2. See http://www.taiwantoday.tw/ct.asp?xItem=232105\&ctNode=2182 and http://www.world-nuclear-news.org/NN-Political-discordplaces-Lungmen-on-hold-2804144.html for more information. 


\section{B-3. Information on global proposed new reactor projects}

\begin{tabular}{|c|c|c|c|c|c|c|c|}
\hline $\begin{array}{c}\frac{\text { NPP }}{\text { Location }} \\
\text { Country }\end{array}$ & $\begin{array}{c}\text { Planned } \\
\text { Const. } \\
\text { Start } \\
\text { Year }\end{array}$ & Location & Reactor Name & Type & MWe & $\begin{array}{l}\text { Reactor } \\
\text { Supplier }\end{array}$ & $\begin{array}{c}\text { Supplier } \\
\text { Country } \\
\text { (Ownership) }\end{array}$ \\
\hline Argentina & 2016 & Lima & Atucha-3 & PHWR & 800 & CNNC & China \\
\hline Argentina & 2017 & Lima & Atucha-4 & Hualong One & 1150 & CNNC & China \\
\hline Armenia & 2018 & Metsamor & Armenia-3 & PWR & 1060 & Rosatom & Russia \\
\hline Bangladesh & 2016 & Rooppur & Rooppur-1 & PWR & 1200 & Rosatom & Russia \\
\hline Bangladesh & 2017 & Rooppur & Rooppur-2 & PWR & 1200 & Rosatom & Russia \\
\hline Chile & 2015 & Antofagasta & NPP-1 & Unknown & 1100 & Unknown & Unknown \\
\hline China & $\underline{2015}$ & Guangxi & Bailong-1 & PWR & 1250 & CPIC & China \\
\hline China & 2017 & Guangxi & Bailong-2 & PWR & 1250 & CPIC & China \\
\hline China & 2015 & $\begin{array}{l}\text { Changjiang, } \\
\text { Hannan } \\
\text { (Hainan) }\end{array}$ & Changjiang-3 & PWR & 650 & $\mathrm{DEC} / \mathrm{CNNC}$ & China \\
\hline China & 2018 & $\begin{array}{l}\text { Changjiang, } \\
\text { Hannan } \\
\text { (Hainan) }\end{array}$ & Changjiang-4 & PWR & 650 & DEC / CNNC & China \\
\hline China & 2016 & $\begin{array}{l}\text { Fangchenggang, } \\
\text { Guangxi }\end{array}$ & Fangchenggang-4 & PWR & 1150 & DEC / CGN & China \\
\hline China & $\underline{2015}$ & $\begin{array}{l}\text { Fangchenggang, } \\
\text { Guangxi }\end{array}$ & Fangchenggang-5 & PWR & 1250 & CGN & China \\
\hline China & 2016 & $\begin{array}{l}\text { Fangchenggang, } \\
\text { Guangxi }\end{array}$ & Fangchenggang-6 & PWR & 1250 & $\mathrm{CGN}$ & China \\
\hline China & & $\begin{array}{l}\text { Cangzhou, } \\
\text { Hebai }\end{array}$ & Haixing-1 & PWR & 1150 & CHD & China \\
\hline China & & $\begin{array}{l}\text { Cangzhou, } \\
\text { Hebai }\end{array}$ & Haixing-2 & PWR & 1150 & CHD & China \\
\hline China & 2015 & $\begin{array}{l}\text { Haiyang, } \\
\text { Shandong }\end{array}$ & Haiyang-3 & PWR & 1250 & WH / CNEC & China \\
\hline China & 2016 & $\begin{array}{l}\text { Haiyang, } \\
\text { Shandong }\end{array}$ & Haiyang-4 & PWR & 1250 & WH / CNEC & China \\
\hline China & 2015 & Guangdong & Huizhou-1 & PWR & 1250 & $\mathrm{CGN}$ & China \\
\hline China & 2018 & Guangdong & Huizhou-2 & PWR & 1250 & $\mathrm{CGN}$ & China \\
\hline China & & $\begin{array}{l}\text { Lufeng, } \\
\text { Guangdong }\end{array}$ & Lufeng-1 & PWR & 1250 & $\mathrm{CGN}$ & China \\
\hline China & & $\begin{array}{l}\text { Lufeng, } \\
\text { Guangdong }\end{array}$ & Lufeng-2 & PWR & 1250 & $\mathrm{CGN}$ & China \\
\hline China & 2017 & $\begin{array}{l}\text { Zhangzhou, } \\
\text { Fujian }\end{array}$ & Ningde-5 & PWR & 1150 & CFHI / CNNC & China \\
\hline China & 2018 & $\begin{array}{l}\text { Zhangzhou, } \\
\text { Fujian }\end{array}$ & Ningde-6 & PWR & 1150 & CFHI / CNNC & China \\
\hline China & $\underline{2016}$ & Jiangxi (Inland) & Pengze-1 & PWR & 1250 & CPIC & China \\
\hline China & 2017 & Jiangxi (Inland) & Pengze-2 & PWR & 1250 & CPIC & China \\
\hline China & 2015 & $\begin{array}{l}\text { Zhangzhou, } \\
\text { Fujian }\end{array}$ & $\underline{\text { Putian-1 }}$ & PWR / SMR & 100 & CGDC & China \\
\hline China & 2015 & $\begin{array}{l}\text { Zhangzhou, } \\
\text { Fujian }\end{array}$ & Putian-2 & PWR / SMR & 100 & CGDC & China \\
\hline China & 2017 & Jiangxi & Ruijin-1 & HTR & 600 & INET / CNEC & China \\
\hline China & 2017 & Jiangxi & Ruijin-2 & HTR & 600 & INET / CNEC & China \\
\hline
\end{tabular}




\begin{tabular}{|c|c|c|c|c|c|c|c|}
\hline $\begin{array}{c}\begin{array}{c}\text { NPP } \\
\text { Location }\end{array} \\
\text { Country }\end{array}$ & $\begin{array}{c}\text { Planned } \\
\text { Const. } \\
\text { Start } \\
\text { Year }\end{array}$ & Location & Reactor Name & Type & MWe & $\begin{array}{l}\text { Reactor } \\
\text { Supplier }\end{array}$ & $\begin{array}{c}\text { Supplier } \\
\text { Country } \\
\text { (Ownership) }\end{array}$ \\
\hline China & 2015 & $\begin{array}{l}\text { Taizhou, } \\
\text { Zhejiang }\end{array}$ & Sanmen-3 & PWR & 1250 & WH / SNPTC & Japan / China \\
\hline China & 2016 & $\begin{array}{l}\text { Taizhou, } \\
\text { Zhejiang } \\
\end{array}$ & Sanmen-4 & PWR & 1250 & WH / SNPTC & Japan / China \\
\hline China & 2011 & Sanming, Fujian & Sanming-1 & FBR & 880 & Rosatom & Russia \\
\hline China & 2011 & Sanming, Fujian & Sanming-2 & FBR & 880 & Rosatom & Russia \\
\hline China & $\underline{2015}$ & $\begin{array}{l}\text { Taishan, } \\
\text { Guangdong }\end{array}$ & Taishan-3 & PWR & 1750 & Unknown & Unknown \\
\hline China & 2018 & $\begin{array}{l}\text { Taishan, } \\
\text { Guangdong }\end{array}$ & Taishan-4 & PWR & 1750 & Unknown & Unknown \\
\hline China & 2016 & Hunan (Inland) & Taohuajiang-1 & PWR & 1250 & CNNC & China \\
\hline China & 2016 & Hunan (Inland) & Taohuajiang-2 & PWR & 1250 & CNNC & China \\
\hline China & 2018 & Hunan (Inland) & Taohuajiang-3 & PWR & 1250 & CNNC & China \\
\hline China & 2018 & Hunan (Inland) & Taohuajiang-4 & PWR & 1250 & CNNC & China \\
\hline China & $\underline{2015}$ & $\begin{array}{l}\text { Lianyungang, } \\
\text { Jiangsu } \\
\end{array}$ & Tianwan-5 & PWR & 1080 & Unknown & Russia \\
\hline China & 2017 & $\begin{array}{l}\text { Lianyungang, } \\
\text { Jiangsu }\end{array}$ & Tianwan-6 & PWR & 1080 & Unknown & Russia \\
\hline China & & Hubei (Inland) & $\begin{array}{l}\text { Xianning (Dafan)- } \\
1\end{array}$ & PWR & 1250 & CGN & China \\
\hline China & & Hubei (Inland) & $\begin{array}{l}\text { Xianning (Dafan)- } \\
2\end{array}$ & PWR & 1250 & CGN & China \\
\hline China & & Hunan & Xiaomoshan-1 & PWR & 1250 & CPIC & China \\
\hline China & & Hunan & Xiaomoshan-2 & PWR & 1250 & CPIC & China \\
\hline China & 2013 & $\begin{array}{l}\text { Xudabao, } \\
\text { Liaoning }\end{array}$ & Xudabao-1 & PWR & 1250 & HSNPC & China \\
\hline China & 2013 & $\begin{array}{l}\text { Xudabao, } \\
\text { Liaoning }\end{array}$ & Xudabao-2 & PWR & 1250 & Unknown & Unknown \\
\hline China & & $\begin{array}{l}\text { Xudabao, } \\
\text { Liaoning }\end{array}$ & Xudabao-3 & PWR & 1250 & Unknown & Unknown \\
\hline China & & $\begin{array}{l}\text { Xudabao, } \\
\text { Liaoning }\end{array}$ & Xudabao-4 & PWR & 1250 & Unknown & Unknown \\
\hline China & & $\begin{array}{l}\text { Xudabao, } \\
\text { Liaoning }\end{array}$ & Xudabao-5 & PWR & 1250 & Unknown & Unknown \\
\hline China & & $\begin{array}{l}\text { Xudabao, } \\
\text { Liaoning }\end{array}$ & Xudabao-6 & PWR & 1250 & Unknown & Unknown \\
\hline China & 2016 & $\begin{array}{l}\text { Zhangzhou, } \\
\text { Fujian }\end{array}$ & Zhangzhou-1 & PWR & 1250 & CGDC & China \\
\hline China & 2016 & $\begin{array}{l}\text { Zhangzhou, } \\
\text { Fujian }\end{array}$ & Zhangzhou-2 & PWR & 1250 & CGDC & China \\
\hline China & 2016 & $\begin{array}{l}\text { Zhangzhou, } \\
\text { Fujian }\end{array}$ & Zhangzhou-3 & PWR & 1250 & CGDC & China \\
\hline China & 2016 & $\begin{array}{l}\text { Zhangzhou, } \\
\text { Fujian }\end{array}$ & Zhangzhou-4 & PWR & 1250 & CGDC & China \\
\hline Egypt & 2016 & $\begin{array}{l}\text { El-Dabaa, } \\
\text { Matrouh }\end{array}$ & El-Dabaa-1 & PWR & 1650 & Rosatom & Russia \\
\hline Egypt & 2016 & $\begin{array}{l}\text { El-Dabaa, } \\
\text { Matrouh }\end{array}$ & El-Dabaa-2 & PWR & 1650 & Rosatom & Russia \\
\hline Egypt & & $\begin{array}{l}\text { El-Dabaa, } \\
\text { Matrouh }\end{array}$ & El-Dabaa-3 & PWR & 1650 & Rosatom & Russia \\
\hline Egypt & & $\begin{array}{l}\text { El-Dabaa, } \\
\text { Matrouh }\end{array}$ & El-Dabaa-4 & PWR & 1650 & Rosatom & Russia \\
\hline Finland & 2018 & Pyhajoki & $\underline{\text { Hanhikivi-1 }}$ & ABWR & 1200 & Rosatom & Russia \\
\hline Hungary & 2018 & Paks & Paks-5 & Unknown & 1200 & Rosatom & Russia \\
\hline
\end{tabular}




\begin{tabular}{|c|c|c|c|c|c|c|c|}
\hline $\begin{array}{c}\text { NPP } \\
\text { Location } \\
\text { Country }\end{array}$ & $\begin{array}{c}\text { Planned } \\
\text { Const. } \\
\text { Start } \\
\text { Year }\end{array}$ & Location & Reactor Name & Type & MWe & $\begin{array}{l}\text { Reactor } \\
\text { Supplier }\end{array}$ & $\begin{array}{c}\text { Supplier } \\
\text { Country } \\
\text { (Ownership) }\end{array}$ \\
\hline India & & $\begin{array}{l}\text { Kaiga, } \\
\text { Karnataka }\end{array}$ & MahiBanswada-1 & PHWR & 700 & $\mathrm{HCC}$ & India \\
\hline India & & $\begin{array}{l}\text { Kaiga, } \\
\text { Karnataka }\end{array}$ & MahiBanswada-2 & PHWR & 700 & $\mathrm{HCC}$ & India \\
\hline India & & $\begin{array}{l}\text { Gorakhpur, } \\
\text { Haryana, } \\
\text { Fatehabad }\end{array}$ & GHAVPP-1 (700) & PHWR & 700 & $\mathrm{HCC}$ & India \\
\hline India & & $\begin{array}{l}\text { Gorakhpur, } \\
\text { Haryana, } \\
\text { Fatehabad } \\
\end{array}$ & GHAVPP-2 (700) & PHWR & 700 & HCC & India \\
\hline India & & $\begin{array}{l}\text { Gorakhpur, } \\
\text { Haryana, } \\
\text { Fatehabad } \\
\end{array}$ & GHAVPP-3 (700) & PHWR & 700 & HCC & India \\
\hline India & & $\begin{array}{l}\text { Gorakhpur, } \\
\text { Haryana, } \\
\text { Fatehabad }\end{array}$ & GHAVPP-4 (700) & PHWR & 700 & $\mathrm{HCC}$ & India \\
\hline India & & $\begin{array}{l}\text { Chutka, Madhya } \\
\text { Pradesh }\end{array}$ & CMAPP-1 & PHWR & 700 & HCC & India \\
\hline India & & $\begin{array}{l}\text { Chutka, Madhya } \\
\text { Pradesh }\end{array}$ & CMAPP-2 & PHWR & 700 & HCC & India \\
\hline India & & $\begin{array}{l}\text { Kaiga, } \\
\text { Karnataka }\end{array}$ & Kaiga-5 & PHWR & 700 & HCC & India \\
\hline India & & $\begin{array}{l}\text { Kaiga, } \\
\text { Karnataka }\end{array}$ & Kaiga-6 & PHWR & 700 & $\mathrm{HCC}$ & India \\
\hline India & & $\begin{array}{l}\text { Tirunellveli- } \\
\text { Kattabomman }\end{array}$ & Kudankulam-3 & PWR & 1000 & Rosatom & Russia \\
\hline India & & $\begin{array}{l}\text { Tirunellveli- } \\
\text { Kattabomman } \\
\end{array}$ & Kudankulam-4 & PWR & 1000 & Rosatom & Russia \\
\hline India & & Ratnagiri & Jaitapur-1 & PWR & 1650 & EDF & France \\
\hline India & & Ratnagiri & Jaitapur-2 & PWR & 1650 & EDF & France \\
\hline India & & $\begin{array}{l}\text { Kovvada, } \\
\text { Andhra Pradesh }\end{array}$ & Kovvada-1 & PWR & 1500 & GE-Hitachi & USA \\
\hline India & & $\begin{array}{l}\text { Kovvada, } \\
\text { Andhra Pradesh }\end{array}$ & Kovvada-2 & PWR & 1500 & GE-Hitachi & USA \\
\hline India & & $\begin{array}{l}\text { Chhaya Mithi } \\
\text { Virdi, Gujarat } \\
\end{array}$ & $\begin{array}{l}\text { ChhayaMithiVirdi- } \\
1\end{array}$ & PWR & 1500 & WH & USA \\
\hline India & & $\begin{array}{l}\text { Chhaya Mithi } \\
\text { Virdi, Gujarat }\end{array}$ & $\begin{array}{l}\text { ChhayaMithiVirdi- } \\
2\end{array}$ & PWR & 1500 & $\mathrm{WH}$ & USA \\
\hline Indonesia & 2017 & $\begin{array}{l}\text { Serpong, } \\
\text { Jakarta }\end{array}$ & NPP-1 & PWR & 10 & $\underline{\text { RENUKO }}$ & Russia \\
\hline Indonesia & 2022 & Jakarta & NPP-2 & PWR & 1000 & Unknown & Unknown \\
\hline$\underline{\text { Iran }}$ & & Halileh & Bushehr-2 & PWR & 1000 & Rosatom & Russia \\
\hline Iran & & Darkhovin & Darkhovin-1 & PWR & 360 & ICRG & Iran \\
\hline Israel & & $\begin{array}{l}\text { No. Negev } \\
\text { Desert }\end{array}$ & \multicolumn{2}{|c|}{ NPP-1 (Joint Venture with Jordan) } & & Unknown & France \\
\hline Japan & 2016 & Omaezaki & $\underline{\text { Hamaoka-6 }}$ & ABWR & 1400 & CHUBU & Japan \\
\hline Japan & & Tsuruga & Tsuruga-3 & APWR & 1538 & JAPC & Japan \\
\hline Japan & & Tsuruga & Tsuruga-4 & APWR & 1538 & JAPC & Japan \\
\hline Jordan & & Amra (North) & Aquba-1 & Unknown & 1000 & Rosatom & Russia \\
\hline Jordan & & Amra (North) & Aquba-2 & Unknown & 1000 & Rosatom & Russia \\
\hline Kazakhstan & & Kurchatov & NPP-1 & PWR & 1200 & Unknown & Russia \\
\hline Kazakhstan & & Balkash & NPP-2 & PWR & 300 & Unknown & Unknown \\
\hline
\end{tabular}




\begin{tabular}{|c|c|c|c|c|c|c|c|}
\hline $\begin{array}{c}\text { NPP } \\
\text { Location } \\
\text { Country }\end{array}$ & $\begin{array}{c}\text { Planned } \\
\text { Const. } \\
\text { Start } \\
\text { Year }\end{array}$ & Location & Reactor Name & Type & MWe & $\begin{array}{l}\text { Reactor } \\
\text { Supplier }\end{array}$ & $\begin{array}{c}\text { Supplier } \\
\text { Country } \\
\text { (Ownership) }\end{array}$ \\
\hline Korea, So. & 2016 & Ulchin-gun & Shin-Hanul-3 & PWR & 1400 & Unknown & Unknown \\
\hline Korea, So. & 2017 & Ulchin-gun & Shin-Hanul-4 & PWR & 1400 & Unknown & Unknown \\
\hline Korea, So. & 2016 & $\begin{array}{l}\text { Gijang-gun, } \\
\text { Busan }\end{array}$ & Shin-Kori-5 & PWR & 1400 & Unknown & Unknown \\
\hline Korea, So. & 2017 & $\begin{array}{l}\text { Gijang-gun, } \\
\text { Busan }\end{array}$ & Shin-Kori-6 & PWR & 1400 & Unknown & Unknown \\
\hline Korea, So. & 2022 & Gyeongbuk & Cheonji-1 & PWR & 1500 & Unknown & Unknown \\
\hline Korea, So. & 2023 & Gyeongbuk & Cheonji-2 & PWR & 1500 & Unknown & Unknown \\
\hline Lithuania & 2015 & Visaginas & Visaginas-1 & ABWR & 1350 & GEH & Japan / USA \\
\hline Nigeria & 2014 & Akwa Ibom & Akwa Ibom-1 & Unknown & 1000 & Rosatom & Russia \\
\hline Nigeria & 2018 & Akwa Ibom & Akwa Ibom-2 & Unknown & 1000 & Rosatom & Russia \\
\hline Nigeria & 2018 & Kogi & Kogi-1 & Unknown & 1000 & Rosatom & Russia \\
\hline Nigeria & 2018 & Kogi & Kogi-2 & Unknown & 1000 & Rosatom & Russia \\
\hline Pakistan & 2015 & Sindh & Karachi Coastal-1 & PWR & 1150 & CNNC & China \\
\hline Pakistan & 2016 & Sindh & Karachi Coastal-2 & PWR & 1150 & CNNC & China \\
\hline Romania & & $\begin{array}{l}\text { Strada } \\
\text { Medgidiei, } \\
\text { Cernavoda }\end{array}$ & Cernavoda-3 & PHWR & 720 & CNPEC & China \\
\hline Romania & & $\begin{array}{l}\text { Strada } \\
\text { Medgidiei, } \\
\text { Cernavoda } \\
\end{array}$ & Cernavoda-4 & PHWR & 720 & CNPEC & China \\
\hline Russia & 2011 & Sosnovyy Bor & Leningrad II-3 & PWR & 1200 & Rosatom & Russia \\
\hline Russia & 2014 & Sosnovyy Bor & Leningrad II-4 & PWR & 1200 & Rosatom & Russia \\
\hline$\underline{\text { So. Africa }}$ & 2010 & Thyspunt & Thyspunt-1 & PWR & 1200 & Unknown & Unknown \\
\hline So. Africa & & Thyspunt & Thyspunt-2 & PWR & 1200 & Unknown & Unknown \\
\hline So. Africa & & Thyspunt & Thyspunt-3 & PWR & 1200 & Unknown & Unknown \\
\hline So. Africa & & Thyspunt & Thyspunt-4 & PWR & 1200 & Unknown & Unknown \\
\hline Spain & & Extremadura & Valdecaballeros-1 & BWR & 939 & GE & USA \\
\hline Spain & & Extremadura & Valdecaballeros- 2 & BWR & 939 & GE & USA \\
\hline Turkey & 2016 & Mersin & Akkuyu-1 & PWR & 1200 & Akkuyu Corp & Russia \\
\hline Turkey & 2017 & Mersin & Akkuyu-2 & PWR & 1200 & Akkuyu Corp & Russia \\
\hline Turkey & 2018 & Mersin & Akkuyu-3 & PWR & 1200 & Akkuyu Corp & Russia \\
\hline Turkey & 2019 & Mersin & Akkuyu-4 & PWR & 1200 & Akkuyu Corp & Russia \\
\hline Turkey & 2017 & Sinop Province & Sinop-1 & PWR & 1120 & AREVA/WH & France/Japan \\
\hline Turkey & 2020 & Sinop Province & Sinop-2 & PWR & 1120 & AREVA/WH & France/Japan \\
\hline Turkey & 2023 & Sinop Province & Sinop-3 & PWR & 1120 & AREVA/WH & France/Japan \\
\hline Turkey & 2024 & Sinop Province & Sinop-4 & PWR & 1120 & AREVA/WH & France/Japan \\
\hline Ukraine & 2016 & $\begin{array}{l}\begin{array}{l}\text { Neteshin } \\
\text { (Netishyn) }\end{array} \\
\end{array}$ & KhNPP-5 & PWR & 950 & ASE & Russia \\
\hline Ukraine & 2016 & $\begin{array}{l}\text { Neteshin } \\
\text { (Netishyn) }\end{array}$ & KhNPP-6 & PWR & 950 & ASE & Russia \\
\hline Ukraine & & $\begin{array}{l}\text { Konstantinovka, } \\
\text { Nikolaev }\end{array}$ & South Ukraine-4 & PWR & 1200 & HYDROPRESS & Ukraine \\
\hline
\end{tabular}




\begin{tabular}{|c|c|c|c|c|c|c|c|}
\hline $\begin{array}{c}\text { NPP } \\
\text { Location } \\
\text { Country }\end{array}$ & $\begin{array}{l}\text { Planned } \\
\text { Const. } \\
\text { Start } \\
\text { Year }\end{array}$ & Location & Reactor Name & Type & MWe & $\begin{array}{l}\text { Reactor } \\
\text { Supplier }\end{array}$ & $\begin{array}{c}\text { Supplier } \\
\text { Country } \\
\text { (Ownership) }\end{array}$ \\
\hline$\underline{\mathrm{UK}}$ & 2016 & Somerset & Hinkley Point C-1 & PWR & 1670 & AREVA & France \\
\hline UK & & Somerset & Hinkley Point C-2 & PWR & 1670 & EDF / CGN & France / China \\
\hline UK & & Suffolk & Sizewell C-1 & PWR & 1670 & EDF / CGN & France / China \\
\hline UK & & Suffolk & Sizewell C-2 & PWR & 1670 & EDF / CGN & France / China \\
\hline UK & $\underline{2017}$ & Wales & Wylfa Newydd-1 & ABWR & 1380 & Horizon & Japan \\
\hline UK & & Wales & Wylfa Newydd-2 & ABWR & 1380 & Horizon & Japan \\
\hline UK & & $\begin{array}{l}\text { Sellafield, } \\
\text { Cumbria }\end{array}$ & Moorside-1 & PWR & 1135 & NuGen & Japan / France \\
\hline UK & & $\begin{array}{l}\text { Sellafield, } \\
\text { Cumbria } \\
\end{array}$ & Moorside-2 & PWR & 1135 & NuGen & Japan / France \\
\hline UK & & $\begin{array}{l}\text { Sellafield, } \\
\text { Cumbria } \\
\end{array}$ & Moorside-3 & PWR & 1135 & NuGen & Japan / France \\
\hline UK & & Dengie & Bradwell-A & PWR & 1150 & $\mathrm{CGN}$ & China \\
\hline UK & & Dengie & Bradwell-B & PWR & 1150 & CGN & China \\
\hline UK & & Cumbria & Sellafield-1 & $\underline{\text { PRISM }}$ & 311 & GEH & Japan \\
\hline UK & & Cumbria & Sellafield-2 & PRISM & 311 & GEH & Japan \\
\hline UK & & Cumbria & Sellafield-3 & CANDU-EC6 & 740 & CEI & Canada \\
\hline UK & & Cumbria & Sellafield-4 & CANDU-EC6 & 740 & CEI & Canada \\
\hline USA & 2008 & $\begin{array}{l}\text { Susquehanna, } \\
\text { PA }\end{array}$ & Bell Bend & US-EPR & 1710 & AREVA & France \\
\hline USA & 2008 & $\begin{array}{l}\text { Crystal River, } \\
\text { FL }\end{array}$ & Levy County-1 & PWR & 1200 & Unknown & USA \\
\hline USA & 2008 & $\begin{array}{l}\text { Crystal River, } \\
\text { FL }\end{array}$ & Levy County-2 & PWR & 1200 & Unknown & USA \\
\hline USA & 2007 & Virginia & North Anna-3 & US-APWR & 1600 & $\mathrm{~B} \& \mathrm{~W}$ & USA \\
\hline USA & 2007 & Bay City, TX & South Texas-3 & ABWR & 1356 & NINA & Japan \\
\hline USA & 2007 & Bay City, TX & South Texas-4 & ABWR & 1356 & NINA & Japan \\
\hline USA & 2009 & Homestead, FL & $\underline{\text { Turkey Point- } 6}$ & PWR & 1200 & Unknown & Unknown \\
\hline USA & 2009 & Homestead, FL & Turkey Point-7 & PWR & 1200 & Unknown & Unknown \\
\hline USA & 2007 & Gaffney, SC & William Lee III-1 & PWR & 1200 & Unknown & USA \\
\hline USA & 2007 & Gaffney, SC & William Lee III-2 & PWR & 1200 & Unknown & USA \\
\hline USA & & Idaho & UAMPS-ID 1-12 & Nuscale & 600 & Nuscale & USA \\
\hline USA & & Clinch River, TN & Clinch River-1 & Unknown & 180 & Unknown & Unknown \\
\hline USA & & Clinch River, TN & Clinch River-2 & Unknown & 180 & Unknown & Unknown \\
\hline USA & & Green River, UT & Green River-1 & PWR & 1200 & $\mathrm{BCH}$ & USA \\
\hline USA & & Green River, UT & Green River-2 & PWR & 1200 & $\mathrm{BCH}$ & USA \\
\hline USA & & Hope Creek, NJ & Salem-3 & PWR & 1200 & Unknown & USA \\
\hline USA & & Ohio & Piketon-1 & US-EPR & 1710 & Unknown & USA \\
\hline USA & & California & Fresno-1 & PWR & 1710 & AREVA & France \\
\hline USA & & Texas & Amarillo-1 & PWR & 1710 & UNISTAR & France \\
\hline USA & & Texas & Amarillo-2 & PWR & 1710 & UNISTAR & France \\
\hline
\end{tabular}




\begin{tabular}{|l|l|l|l|l|l|l|l|}
\hline $\begin{array}{c}\text { NPP } \\
\text { Location } \\
\text { Country }\end{array}$ & $\begin{array}{c}\text { Planned } \\
\text { Const. } \\
\text { Start } \\
\text { Year }\end{array}$ & Location & Reactor Name & Type & MWe & $\begin{array}{c}\text { Reactor } \\
\text { Supplier }\end{array}$ & $\begin{array}{c}\text { Supplier } \\
\text { Country } \\
\text { (Ownership) }\end{array}$ \\
\hline Vietnam & 2019 & Phuoc Dinh & Ninh Thuan 1-1 & PWR & 1200 & Rosatom & Russia \\
\hline Vietnam & 2020 & Phuoc Dinh & Ninh Thuan 1-2 & PWR & 1200 & Rosatom & Russia \\
\hline Vietnam & & Vinh Hai & Ninh Thuan 2-3 & PWR & 1100 & Unknown & Japan \\
\hline Vietnam & & Vinh Hai & Ninh Thuan 2-4 & PWR & 1100 & Unknown & Japan \\
\hline
\end{tabular}




\section{B-4. Information on current global fuel fabrication facilities by function}

\begin{tabular}{|c|c|c|c|c|c|}
\hline $\begin{array}{c}\text { Host } \\
\text { Country }\end{array}$ & Facility Name & Facility/Fuel Type & $\begin{array}{l}\text { Design } \\
\text { Capacity }\end{array}$ & Owner & Operator \\
\hline Belgium & $\underline{\text { FBFC International - MOX }}$ & $\begin{array}{l}\text { Fuel Fabrication (MOX } \\
\text { Assembly) }\end{array}$ & $\begin{array}{l}100 \mathrm{t} \\
\mathrm{HM} / \text { year }\end{array}$ & $\underline{\text { FBFC - Belgium }}$ & FBFC - Belgium \\
\hline France & AREVA NC Melox & $\begin{array}{l}\text { Fuel Fabrication (MOX } \\
\text { Assembly) }\end{array}$ & $\begin{array}{l}195 \mathrm{t} \\
\text { HM/year }\end{array}$ & Joint Venture & AREVA NC \\
\hline Argentina & Ezeiza - Nuclear Fuel Manufacture Plant & $\begin{array}{l}\text { Fuel Fabrication (HWR } \\
\text { Assembly) }\end{array}$ & $\begin{array}{l}270 \mathrm{t} \\
\mathrm{HM} / \text { year }\end{array}$ & CNEA - Argentina & Unknown \\
\hline Brazil & INB - FCN Resende - Unit 1 & Fuel Fabrication (U Assembly) & $\begin{array}{l}240 \mathrm{t} \\
\mathrm{HM} / \text { year }\end{array}$ & INB - Brazil & INB - Brazil \\
\hline Canada & Peterborough Facility & $\begin{array}{l}\text { Fuel Fabrication (HWR } \\
\text { Assembly) }\end{array}$ & $\begin{array}{l}1200 \mathrm{t} \\
\mathrm{HM} / \text { year }\end{array}$ & $\underline{\mathrm{GEH}-\mathrm{C}}$ & $\mathrm{GEH}-\mathrm{C}$ \\
\hline Canada & Zircatec Precision Ind. - Port Hope & $\begin{array}{l}\text { Fuel Fabrication (HWR } \\
\text { Assembly) }\end{array}$ & $\begin{array}{l}1200 \mathrm{t} \\
\mathrm{HM} / \text { year }\end{array}$ & $\begin{array}{l}\text { Cameco Fuel Manufacturing } \\
\text { Inc. }\end{array}$ & Cameco \\
\hline China & CANDU Fuel Plant & $\begin{array}{l}\text { Fuel Fabrication (HWR } \\
\text { Assembly) }\end{array}$ & $\begin{array}{l}200 \mathrm{t} \\
\mathrm{HM} / \text { year }\end{array}$ & Joint Venture & $\begin{array}{l}\text { Baotou Nuclear Fuel } \\
\text { Element Plant }\end{array}$ \\
\hline China & Yibin Nuclear Fuel Element Plant & Fuel Fabrication (U Assembly) & $\begin{array}{l}400 \mathrm{t} \\
\mathrm{HM} / \text { year }\end{array}$ & CNNC - China & $\begin{array}{l}\text { Yibin Nuclear Fuel } \\
\text { Element Plant }\end{array}$ \\
\hline France & FBFC - Romans & Fuel Fabrication (U Assembly) & $\begin{array}{l}1400 \mathrm{t} \\
\mathrm{HM} / \text { year }\end{array}$ & Joint Venture & FBFC International NV \\
\hline Germany & Advanced Nuclear Fuels GmbH Lingen Plant & Fuel Fabrication (U Assembly) & $\begin{array}{l}650 \mathrm{t} \\
\mathrm{HM} / \text { year }\end{array}$ & Framatome ANP & ANF - Germany \\
\hline India & NFC (BWR) & Fuel Fabrication (U Assembly) & 24 t HM/year & DAE - India & NFC - India \\
\hline India & NFC - (PHWR) - Block-A & $\begin{array}{l}\text { Fuel Fabrication (HWR } \\
\text { Assembly) }\end{array}$ & $\begin{array}{l}300 \mathrm{t} \\
\mathrm{HM} / \text { year }\end{array}$ & DAE - India & NFC - India \\
\hline India & NFC (PHWR)-2 & $\begin{array}{l}\text { Fuel Fabrication (HWR } \\
\text { Assembly) }\end{array}$ & $\begin{array}{l}300 \mathrm{t} \\
\mathrm{HM} / \text { year }\end{array}$ & DAE - India & NFC - India \\
\hline Japan & Global Nuclear Fuel-Japan Co. Ltd. (GNF-J) & Fuel Fabrication (U Assembly) & $\begin{array}{l}750 \mathrm{t} \\
\mathrm{HM} / \text { year }\end{array}$ & GNFJ - Japan & GNFJ - Japan \\
\hline Japan & Mitsubishi Nuclear Fuel Ltd. (MNF) & Fuel Fabrication (U Assembly) & $\begin{array}{l}440 \mathrm{t} \\
\mathrm{HM} / \text { year }\end{array}$ & Joint Venture & MNF - Japan \\
\hline Japan & Nuclear Fuel Industry Ltd. (NFI Kumatori) & Fuel Fabrication (U Assembly) & $\begin{array}{l}284 \mathrm{t} \\
\mathrm{HM} / \text { year }\end{array}$ & Joint Venture & $\mathrm{NFI}$ - Japan \\
\hline Japan & Nuclear Fuel Industry Ltd. (NFI Tokai) & Fuel Fabrication (U Assembly) & $\begin{array}{l}200 t \\
\text { HM/year }\end{array}$ & Joint Venture & $\mathrm{NFI}$ - Japan \\
\hline
\end{tabular}




\begin{tabular}{|c|c|c|c|c|c|}
\hline Korea, So. & CANDU Fuel Fabrication Plant (2) & $\begin{array}{l}\text { Fuel Fabrication (HWR } \\
\text { Assembly) }\end{array}$ & $\begin{array}{l}400 \mathrm{t} \\
\mathrm{HM} / \text { year }\end{array}$ & Joint Venture & KNFC - So. Korea \\
\hline Korea, So. & PWR Fuel Fabrication Plant & Fuel Fabrication (U Assembly) & $\begin{array}{l}400 \mathrm{t} \\
\mathrm{HM} / \text { year }\end{array}$ & Joint Venture & KNFC - So. Korea \\
\hline Pakistan & Chashma & $\begin{array}{l}\text { Fuel Fabrication (HWR } \\
\text { Assembly) }\end{array}$ & 20 t HM/year & PAEC - Pakistan & PAEC - Pakistan \\
\hline Romania & Nuclear Fuel Plant Subsidiary Pitesti (FCN Pitesti) & $\begin{array}{l}\text { Fuel Fabrication (HWR } \\
\text { Assembly) }\end{array}$ & $\begin{array}{l}200 \mathrm{t} \\
\mathrm{HM} / \text { year }\end{array}$ & $\underline{\mathrm{SNN} \text { - Romania }}$ & FCNP - Romania \\
\hline Russia & Machine - Building Plant (FBR) & Fuel Fabrication (U Assembly) & 50 t HM/year & JSC TVEL - Russia & JSC MSZ - Russia \\
\hline Russia & Machine - Building Plant (LWR) & Fuel Fabrication (U Assembly) & $\begin{array}{l}950 \mathrm{t} \\
\mathrm{HM} / \text { year }\end{array}$ & JSC TVEL - Russia & JSC MSZ - Russia \\
\hline Russia & Machine - Building Plant (RBMK) & Fuel Fabrication (U Assembly) & $\begin{array}{l}460 \mathrm{t} \\
\mathrm{HM} / \text { year }\end{array}$ & JSC TVEL - Russia & JSC MSZ - Russia \\
\hline Russia & $\begin{array}{l}\text { Novosibirsk Chemical Concentrates Plant } \\
\text { (Assembly) }\end{array}$ & Fuel Fabrication (U Assembly) & $\begin{array}{l}1200 \mathrm{t} \\
\mathrm{HM} / \text { year }\end{array}$ & JSC TVEL - Russia & JSC NCCP - Russia \\
\hline Spain & Fabrica de combustible & Fuel Fabrication (U Assembly) & $\begin{array}{l}400 \mathrm{t} \\
\mathrm{HM} / \text { year }\end{array}$ & Joint Venture & $\begin{array}{l}\text { ENUSA Industrias } \\
\text { Avanzadas, SA }\end{array}$ \\
\hline Sweden & Westinghouse Electric Sweden AB & Fuel Fabrication (U Assembly) & $\begin{array}{l}600 \mathrm{t} \\
\mathrm{HM} / \text { year }\end{array}$ & $\underline{\text { WH - Japan }}$ & $\begin{array}{l}\text { Westinghouse Electric } \\
\text { Sweden } A B\end{array}$ \\
\hline UK & Springfields OFC AGR Line & $\begin{array}{l}\text { Fuel Fabrication (GCR } \\
\text { Assembly) }\end{array}$ & $\begin{array}{l}290 \mathrm{t} \\
\mathrm{HM} / \text { year }\end{array}$ & NDA - UK & WH - UK \\
\hline UK & Springfields OFC LWR Line & Fuel Fabrication (U Assembly) & $\begin{array}{l}330 \mathrm{t} \\
\mathrm{HM} / \text { year }\end{array}$ & NDA - UK & WH - UK \\
\hline USA & Columbia (Westinghouse) & Fuel Fabrication (U Assembly) & $\begin{array}{l}1150 \mathrm{t} \\
\mathrm{HM} / \text { year }\end{array}$ & $\underline{\text { WH - Japan }}$ & $\underline{\text { WH - Japan }}$ \\
\hline USA & Lynchburg - FC Fuels & Fuel Fabrication (U Assembly) & $\begin{array}{l}400 \mathrm{t} \\
\mathrm{HM} / \text { year }\end{array}$ & Joint Venture & AREVA NP \\
\hline USA & Richland (ANF) & Fuel Fabrication (U Assembly) & $\begin{array}{l}700 \mathrm{t} \\
\mathrm{HM} / \text { year }\end{array}$ & AREVA & AREVA \\
\hline USA & Wilmington (GNF) & Fuel Fabrication (U Assembly) & $\begin{array}{l}1200 \mathrm{t} \\
\mathrm{HM} / \text { year }\end{array}$ & GE - Japan & GE - Japan \\
\hline Canada & N. Fuel PLLT. OP. - Toronto & Fuel Fabrication (U Pellet-Pin) & $\begin{array}{l}1300 \mathrm{t} \\
\mathrm{HM} / \text { year }\end{array}$ & $\underline{\mathrm{GEH}-\mathrm{C}}$ & $\underline{\mathrm{GEH}-\mathrm{C}}$ \\
\hline India & NFC (PELLET) & Fuel Fabrication (U Pellet-Pin) & $\begin{array}{l}335 \mathrm{t} \\
\mathrm{HM} / \text { year }\end{array}$ & DAE - India & NFC - India \\
\hline Kazakhstan & Ulba Metalurgical Plant (UMP) & Fuel Fabrication (U Pellet-Pin) & $\begin{array}{l}2800 \mathrm{t} \\
\mathrm{HM} / \text { year }\end{array}$ & Kazatomprom & ULBA Metallurgical Co. \\
\hline Russia & Machine - Building Plant (Pellets) & Fuel Fabrication (U Pellet-Pin) & $\begin{array}{l}1100 \mathrm{t} \\
\mathrm{HM} / \text { year }\end{array}$ & JSC TVEL - Russia & JSC MSZ - Russia \\
\hline Brazil & INB - Fabrica de Combustivel Nuclear & Re-conversion to UO2 Powder & $\begin{array}{l}120 \mathrm{t} \\
\mathrm{HM} / \text { year }\end{array}$ & INB - Brazil & INB - Brazil \\
\hline
\end{tabular}




\begin{tabular}{|c|c|c|c|c|c|}
\hline Japan & Mitsubushi Nuclear Fuel Ltd. (MNF) & Re-conversion to UO2 Powder & $\begin{array}{l}450 \mathrm{t} \\
\mathrm{HM} / \text { year }\end{array}$ & Joint Venture & MNF - Japan \\
\hline USA & Paducah & Re-conversion to UO2 Powder & $\begin{array}{l}18000 \mathrm{t} \\
\mathrm{HM} / \text { year }\end{array}$ & Unknown & $\underline{B W X T}$ \\
\hline USA & Portsmouth & Re-conversion to UO2 Powder & $\begin{array}{l}13500 \mathrm{t} \\
\mathrm{HM} / \text { year }\end{array}$ & Unknown & BWXT \\
\hline Argentina & Ezeiza - Special Alloy Fabrication & Zirconium Alloy Production & $10 \mathrm{t} /$ year & CNEA - Argentina & FAE SA - Argentina \\
\hline France & CEZUS - Jarrie & Zirconium Alloy Production & $2200 \mathrm{t} /$ year & Framatome ANP & AREVA \\
\hline France & CEZUS - Rugles & Zirconium Alloy Production & $600 \mathrm{t} /$ year & Framatome ANP & AREVA \\
\hline France & CEZUS - Ugine & Zirconium Alloy Production & $2200 \mathrm{t} /$ year & Framatome ANP & AREVA \\
\hline India & $\underline{N F C-(Z I R)}$ & Zirconium Alloy Production & $250 \mathrm{t} /$ year & DAE - India & $\underline{N F C-I n d i a}$ \\
\hline India & $\underline{\mathrm{NFC}}$ (NZSP) & Zirconium Alloy Production & $250 \mathrm{t} /$ year & $\underline{D A E}$ - India & $\underline{N F C-I n d i a}$ \\
\hline USA & Wah Chang - Albany & Zirconium Alloy Production & 2000 t/year & $\underline{\text { ATI - USA }}$ & Wah Chang \\
\hline USA & Western Zirconium & Zirconium Alloy Production & $1350 \mathrm{t} /$ year & WH - Japan & WH - Japan \\
\hline Argentina & Ezeiza - Special Alloy Fabrication & Zirconium Alloy Tubing & $300 \mathrm{~km} /$ year & CNEA - Argentina & FAE SA - Argentina \\
\hline Canada & General Electric Canada Inc. - Arnprior & Zirconium Alloy Tubing & 1350 km/year & $\underline{\mathrm{GEH}}-\mathrm{C}$ & $\underline{\mathrm{GEH}}-\mathrm{C}$ \\
\hline Canada & Nuclear Product Department - Cobourgh & Zirconium Alloy Tubing & $950 \mathrm{~km} /$ year & Cameco & $\underline{\text { Cameco }}$ \\
\hline France & CEZUS - Montreuil Juigné & Zirconium Alloy Tubing & 1200 t/year & Framatome ANP & AREVA \\
\hline France & CEZUS - Paimboeuf & Zirconium Alloy Tubing & $5000 \mathrm{~km} /$ year & Framatome ANP & AREVA \\
\hline Germany & Advanced Nuclear Fuels GmbH Duisburg Plant & Zirconium Alloy Tubing & $2100 \mathrm{~km} /$ year & ANF - Germany & ANF - Germany \\
\hline India & NFC - Hyderabad (ZSP) & Zirconium Alloy Tubing & $180 \mathrm{t} /$ year & DAE - India & NFC - India \\
\hline India & NFC (NZFP) & Zirconium Alloy Tubing & 59 t/year & DAE - India & NFC - India \\
\hline India & NFC (ZFP) & Zirconium Alloy Tubing & 80 t/year & DAE - India & $\underline{N F C-I n d i a}$ \\
\hline Japan & $\begin{array}{l}\text { Mitsubishi Materials Corporation - Okegawa } \\
\text { Plant }\end{array}$ & Zirconium Alloy Tubing & $800 \mathrm{~km} / \mathrm{year}$ & $\underline{M M C-J a p a n}$ & MMC - Japan \\
\hline Japan & Zirco Products Chofu-kita & Zirconium Alloy Tubing & $1400 \mathrm{~km} /$ year & Joint Venture & $\begin{array}{l}\text { Zirco Products Co., } \\
\text { Ltd. }\end{array}$ \\
\hline Russia & Chepetski Machine Plant - Zircaloy & Zirconium Alloy Tubing & 650 t/year & JSC TVEL - Russia & JSC CMP - Russia \\
\hline Sweden & Sandvik Materials Technology & Zirconium Alloy Tubing & 1000 km/year & AB Sandvik Steel & AB Sandvik Steel \\
\hline USA & Allens Park & Zirconium Alloy Tubing & 500 km/year & Nikko-Wolverine, Inc. & Nikko-Wolverine, Inc. \\
\hline USA & Kennewick & Zirconium Alloy Tubing & 2200 km/year & Sandvik Special Metals Corp. & $\begin{array}{l}\text { Sandvik Special Metals } \\
\text { Corp. }\end{array}$ \\
\hline USA & Wilmington & Zirconium Alloy Tubing & 2200 km/year & GE - Japan & GE - Japan \\
\hline
\end{tabular}

